UNIVERSIDADE DE SÃO PAULO

FACULDADE DE ECONOMIA, ADMINISTRAÇÃO E CONTABILIDADE DEPARTAMENTO DE ECONOMIA

PROGRAMA DE PÓS-GRADUAÇÃO EM ECONOMIA

ANTONIO CARLOS PASSOS FILHO

O endividamento dos estados brasileiros: uma análise de sustentabilidade e dos instrumentos de controle

São Paulo 
Prof. Dr. Vahan Agopyan

Reitor da Universidade de São Paulo

Prof. Dr. Adalberto Américo Fischmann

Diretor da Faculdade de Economia, Administração e Contabilidade Prof. Dr. Hélio Nogueira da Cruz

Chefe do Departamento de Economia

Prof. Dr. Ariaster Baumgratz Chimeli

Coordenador do Programa de Pós-Graduação em Economia 


\title{
O ENDIVIDAMENTO DOS ESTADOS BRASILEIROS: UMA ANÁLISE DE SUSTENTABILIDADE E DOS INSTRUMENTOS DE CONTROLE
}

\begin{abstract}
Dissertação apresentada ao Programa de Pós Graduação em Economia do Departamento de Economia da Faculdade de Economia, Administração e Contabilidade da Universidade de São Paulo, como requisito parcial para a obtenção do título de Mestre em Ciências.
\end{abstract}

Orientador: Prof. Dr. Siegfried Bender

Versão Corrigida

São Paulo 


\section{FICHA CATALOGRÁFICA}

Elaborada por Rafael Mielli Rodrigues - CRB-8/7286

\section{Seção de Processamento Técnico do SBD/FEA/USP}

Passos Filho, Antonio Carlos

O endividamento dos estados brasileiros: uma análise de sustentabilidade e dos instrumentos de controle / Antonio Carlos Passos Filho. -São Paulo, 2018.

$120 \mathrm{p}$.

Dissertação (Mestrado) - Universidade de São Paulo, 2018.

Orientador: Siegfried Bender.

1. Dívida pública 2. Política fiscal 3. Finanças públicas I. Universidade de São Paulo. Faculdade de Economia, Administração e Contabilidade. II. Título.

CDD - 336.34 

Dedico este trabalho à memória de Vitória Mansur, que gostava de dizer que era "minha fã número um", e que certamente se prontificaria a ser a primeira ler este trabalho assim que estivesse pronto. Saudades eternas. 



\section{AGRADECIMENTOS}

De início, agradeço aos meus pais, Tânia e Antonio, e à minha irmã, Marília, pelo constante apoio e suporte desde sempre, mas em especial a partir da escolha de que me aprofundaria no estudo acadêmico. Este trabalho não seria possível sem vocês. Serei sempre grato por tudo que fazem por mim.

Agradeço também à Stéphanie pelo companheirismo insuperável até nas horas mais difíceis. Em nenhum momento houve uma palavra que não fosse de amparo, entusiasmo ou compreensão. Seu interesse é sempre o meu êxito e felicidade, e ao seu lado espero sempre ser recíproco nessas atitudes.

Aos meus familiares, como um todo, mas principalmente Rafael, Julyana, minha afilhada Rafaella, Karina, Daniela, Nathalia e Júlio. Por saber que sempre posso contar com vocês em todos os momentos, independente da distância.

À turma do mestrado do IPE-USP de 2016, em especial ao amigo de longa data Igor Rose, mas também Adriano dos Reis, Luiz Superti, Michael França e Thales Maion pela constante ajuda, muitas vezes não correspondida (não intencionalmente!), ao longo do curso.

Pela orientação, disponibilidade, interesse e atenção, sou grato ao prof. Dr. Siegfried Bender, com um agradecimento também à sua secretária Felisbela Rossetti, sempre solícita ao longo do trabalho.

Agradeço pelos comentários, críticas e sugestões a profa. Dra. Fabiana Fontes Rocha e o prof. Dr. Fernando Antonio Slaibe Postali, tanto quando das bancas de qualificação e de avaliação de progresso, quanto nas reuniões e conversas. À Faculdade de Economia, Administração e Contabilidade da Universidade de São Paulo, ao coordenador do curso de pós-graduação e aos professores desta, pelo conhecimento compartilhado ao longo do curso.

Ao Conselho Nacional de Desenvolvimento de Desenvolvimento Científico e Tecnológico, pela concessão da bolsa de mestrado para a realização desta pesquisa. 



\section{RESUMO}

A Lei de Responsabilidade Fiscal (LRF) foi criada em 2000, tendo como um de seus objetivos o de controlar e limitar o processo de endividamento dos estados brasileiros. No entanto, em 2016, a União acertou o refinanciamento das dívidas de alguns destes estados. Este trabalho busca analisar esta aparente contradição; a crise dos estados teria como origem fatores exógenos à LRF ou os mecanismos da LRF não foram suficientes para conter o comportamento de endividamento excessivo dos estados? Utilizando a metodologia de Bohn (1998), estimou-se cinco modelos: painel completo, separação regional, separação por critério endógeno, separação por gasto com pessoal em relação a receita corrente líquida e separação pelo critério da Resolução de número 40 do Senado Federal. As estimações contemplam quatro períodos: 2001 a 2015; 2008 a 2015; 2001 a 2020 e 2008 a 2020, e consideram tanto a dívida consolidada líquida quanto a bruta. Os resultados apontam que os instrumentos que foram criados são ineficientes, pois estados que não estão constrangidos por nenhuma punição da LRF não possuem uma trajetória sustentável da dívida. Por consequência, é reforçada a ideia de que há um comportamento de risco moral por parte dos estados, que procuram endividar-se excessivamente por considerarem que a dívida será renegociada pela União, comportamento este que só pode ser combatido a partir de aprimoramentos institucionais.

Palavras chave: Sustentabilidade da dívida pública. Política Fiscal. Lei de Responsabilidade Fiscal 



\begin{abstract}
The "Fiscal Responsibility Law" (LRF) was created in 2000, having as one of its pillars the control of the regional states' indebtedness process. However, in 2016, the federal government approved the refinance of such debts for some states. This paper seeks to analyze this seeming contradiction: the states' crysis is due to factors that are exogenous to the LRF, or are the LRF mechanisms not sufficient to restrain the excessive indebtness by the states? Using Bohn's methodology (1998), five models are estimated: complete pannel, regional separation, separation by an endogenous criteria, separation by LRF's resolution to stafe workers expending (wages, pensions, etc) and separation by a Senate resolution's criteria. The estimations are made in four time frames: 2001-2015; 2008-2015; 2001-2020; 2008-2020, and both the net debt and the gross debt are considered. Results indicate that the instruments that were created by the LRF are inefficient, in the sense that states that are not punished or affected by said instruments do not follow a sustainable fiscal policy. Consequently, the idea of a moral hazard behaviour is reemforced: the states expect that the federal government will refinance its debt, so they do not follow a sustainable fiscal policy. This behaviour can only be stopped through institucional reforms.
\end{abstract}

Keywords: Public debt sustainability. Fiscal policy. Fiscal responsability law. 



\section{ÍNDICE DE GRÁFICOS}

Gráfico 1 - Relação consolidada do gasto com pessoal como proporção da receita corrente líquida dos estados brasileiros ......................................... 27

Gráfico 2 - Receita corrente líquida dos estados a preços correntes ...... 30 Gráfico 3 - Dívida consolidada bruta e dívida consolidada líquida dos estados.

Gráfico 4 - Receita corrente líquida total dos estados a preços de 2008 . 32 Gráfico 5 - Despesa com pessoal estadual consolidada do poder executivo 


\section{ÍNDICE DE TABELAS}

Tabela 1 - Relação de gasto com pessoal como proporção da receita corrente líquida para o poder executivo

Tabela 2 - Valores para o resultado primário, dívida consolidada líquida e bruta para os estados brasileiros ao fim de 2017

Tabela 3 - Supremos e ínfimos para o conjunto de variáveis de interesse.36

Tabela 4 - Teste de Im, Pesaran e Shin (2003) ............................................. 62

Tabela 5 - Teste de cointegração para o modelo A ……………………….... 64

Tabela 6 - Teste de cointegração para o modelo B ..................................... 65

Tabela 7 - Modelo 1: Painel Completo ……….......................................... 67

Tabela 8 - Modelo 2: Estimação por Regiões............................................ 68

Tabela 9 - Modelo 3: Limite Endógeno ……………….................................. 73

Tabela 10 - Modelo 4: Gastos com Pessoal sobre Receita Corrente Líquida 76

Tabela 11 - Modelo 5: Relação DCL/RCL.................................................... 79 


\section{SUMÁRIO}

1 INTRODUÇÃO

2 ANÁLISE HISTÓRICA DO ENDIVIDAMENTO ESTADUAL ....................... 21

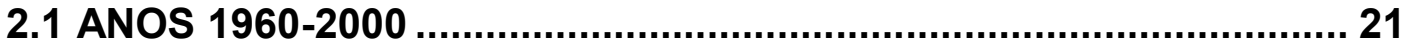

2.2 A LEI DE RESPONSABILIDADE FISCAL E OS ANOS SEGUINTES 26

2.3 A NOVA RENEGOCIAÇÃO DAS DÍVIDAS ESTADUAIS: UM PROBLEMA DE RISCO MORAL? ....................................................... 34

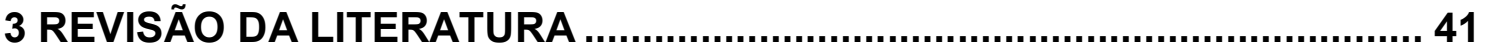

3.1 LITERATURA SOBRE DADOS INTERNACIONAIS .......................... 41

3.2 LITERATURA SOBRE DADOS NACIONAIS .....................................46

4 METODOLOGIA

5 RESULTADOS

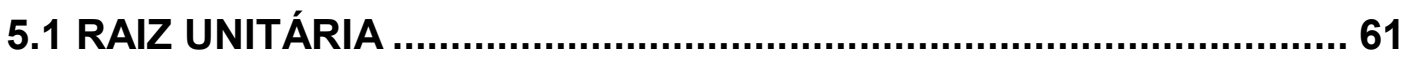

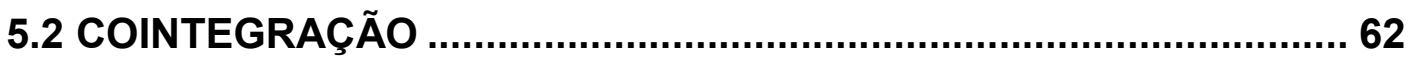

5.3 ESTIMAÇÃO DA FUNÇÃO DE REAÇÃO FISCAL..............................6

6 CONCLUSÃO

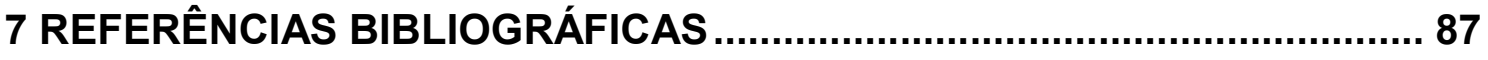

ANEXO A - GRÁFICO DAS VARIÁVEIS DE INTERESSE POR CROSS

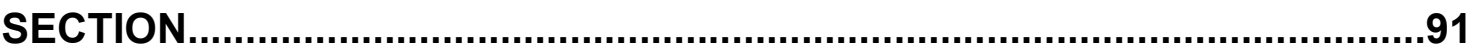

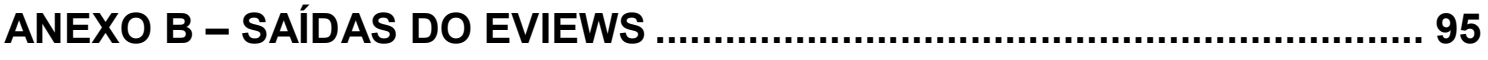






\section{INTRODUÇÃO}

Em 28 de dezembro de 2016 foi regulamentada a Lei Complementar de número 156, resultado de um acordo entre a União e Estados ${ }^{1}$. A lei estabeleceu o Plano de Auxílio aos Estados e medidas de estímulo ao reequilíbrio fiscal. Dentre as medidas apresentadas, estão o alongamento da dívida estadual por vinte anos, com desconto nas parcelas até junho de 2018, e a renegociação das operações de crédito pelo BNDES. Como contrapartida, os Estados se comprometeram a não aumentar as suas despesas, em relação ao ano anterior, acima da inflação do período, bem como a aderir ao Novo Programa de Apoio à Reestruturação e ao Ajuste Fiscal dos Estados (PAF), instrumento que serviria de auxílio ao cumprimento das prerrogativas da Lei de Responsabilidade Fiscal (LRF).

Em 11 de setembro de 1997, pouco menos de vinte anos antes, era sancionada a lei de número 9.496. A lei previa a assunção, consolidação e refinanciamento das dívidas estaduais pela União por trinta anos. O montante da dívida que foi refinanciada atingiu $12 \%$ do PIB de 1997. Como contrapartida, foi criado o Programa de Apoio à Reestruturação e ao Ajuste Fiscal dos Estados.

A semelhança entre os dispositivos legais é nítida. O quadro de semelhanças se amplia quando se considera os dispositivos da Lei de número 8.727, de 1993, que decretava o refinanciamento das operações de crédito interno pelo prazo de vinte anos. A lei 7.976, de 1989, estabelecia que a União refinanciaria, pelo prazo de vinte anos, as dívidas estaduais derivadas de empréstimos concedidos pela União. No entanto, o contexto político e econômico que levou à promulgação destas leis não é o mesmo.

Como aponta Mora (2002), a centralização tributária promovida pela União durante a ditadura militar promoveu dificuldades orçamentárias para os governadores. Houve aumento na utilização de operações de crédito, bem como buscou-se empréstimos no exterior, com atuação proeminente dos bancos estatais. A crise da

\footnotetext{
${ }^{1}$ Os Estados do Amapá, Amazonas, Bahia, Distrito Federal, Maranhão, Piauí, Rio Grande do Norte, Roraima, Tocantins não solicitaram adesão à renegociação com a União. Para efeito de simplificação, o Distrito Federal pertencerá ao grupo dos estados neste trabalho.
} 
década de 80 , após o segundo choque do petróleo, atingiu fortemente as finanças estatais.

A promulgação da Constituição Federal de 1988 marcou o início da redemocratização e buscou institucionalizar a descentralização fiscal. Com o aumento da importância relativa dos Estados como parte de uma federação, o refinanciamento das dívidas estaduais por parte da União começou a ser negociado, até mesmo para garantir o êxito do novo momento político, como afirma Lopreato (2000). É neste contexto que se dá a renegociação das dívidas, institucionalizada pela lei 7.976, que não previa contrapartida por parte dos Estados.

Em 1993, entrava em vigor o Programa de Ação Imediata (PAl). Segundo o diagnóstico deste programa, era necessário que a União revesse o funcionamento dos bancos estaduais, promovendo corte de gastos e exigindo dos estados um comportamento mais austero. Ainda assim, dado o cenário de hiperinflação, houve a renegociação da dívida, expressa na lei 8.727 , visando dar aos Estados um alívio em seu caixa.

O fim do processo inflacionário, materializado no plano Real do ano seguinte, representou um esforço adicional para os estados. A eliminação do chamado "imposto inflacionário" implicou em mais uma crise de receitas para estes entes federativos, que novamente se viram em posição desfavorecida. A renegociação de 1997, materializada pela lei 9.496, promoveu a renegociação das dívidas estaduais. No entanto, a contrapartida foi clara: os estados deveriam se submeter ao Programa de Apoio à Reestruturação e ao Ajuste Fiscal. A ideia era que os entes federativos estabelecessem metas e compromissos anuais sobre parâmetros fiscais. No ano seguinte, o cumprimento destas metas e compromissos seria avaliado pelo Ministério da Fazenda, e este processo, de maneira contínua, garantiria que as metas fossem representativas em relação a atuação do ente, gerando planejamento de longo prazo em que o problema do endividamento excessivo se reduziria com o tempo.

Em 4 de maio de 2000 é aprovada a Lei Complementar de número 101, denominada Lei de Responsabilidade Fiscal (LRF). A lei tem como princípios o planejamento, transparência, responsabilização e controle dos gastos públicos. Seria, de certa forma, o complemento e o fechamento dos mecanismos da lei 9.496. A lei traz limites e metas para o endividamento, para gastos com pessoal, para operações 
de antecipação de receitas orçamentárias, dentre outros. Como afirma Giambiagi e Mora (2005), a ideia é circunscrever a atuação política estatal ao seu espaço fiscal.

Isto porque a emissão de dívida é uma das políticas fiscais ao alcance de um governo de forma a atingir os seus objetivos, seja ele o de viabilizar investimentos, realizar pagamentos, dentre outros. No entanto, esta emissão tem um custo. Como mostram Sargent e Wallace (1981), a emissão de títulos da dívida acaba por afetar o nível de preços e aumentar a taxa de juros, com efeitos sobre a atividade econômica.

Essa relação de custos e benefícios sugere que deve haver um equilíbrio por parte do governo na condução de sua política fiscal. À esta noção que se define sustentabilidade. A sustentabilidade da dívida, para Blanchard (1990), estaria associada à convergência da trajetória para o seu valor inicial. Para Flavin e Hamilton (1986), a política fiscal será sustentável se a trajetória do valor esperado dos superávits primários futuros for igual ao montante inicial da dívida. Para Bohn (2007), se o governante reage a uma variação na dívida gerando superávit primário, então a trajetória da dívida seguirá uma trajetória balanceada. Por fim, o FMI (2002) sugere que a dívida é sustentável quando o ente que adquiriu a dívida continua pagando os serviços da dívida sem que isto exija uma contrapartida excessiva em seu padrão de renda e consumo.

A partir da instituição da LRF e de seus mecanismos de limites ao endividamento em vários níveis, com nominadas punições em caso de desvio, esperava-se que os estados caminhassem para uma trajetória de endividamento que fosse sustentável, à luz dos conceitos abordados anteriormente.

No entanto, a promulgação da Lei Complementar de número 156, ao autorizar uma nova renegociação das dívidas estaduais, é um demonstrativo institucional de que houve um desequilíbrio fiscal por parte dos estados.

A existência e perpetuação de tal desequilíbrio fiscal sugere a existência de um comportamento de risco moral por parte dos governantes, em especial quando se leva em conta o número de refinanciamentos da dívida estadual durante as décadas de 80 e 90. Se um governador enxerga que, no futuro, a dívida de seu estado será refinanciada pela União, é gerado então um forte incentivo para que este estado siga uma trajetória da dívida acima daquela dita como sustentável, posto que o ônus desta 
atitude ficará com a União, e os benefícios, principalmente políticos, serão exclusivamente do governador.

Caberia, então, aos mecanismos institucionais, como a LRF, frear este comportamento por parte dos governantes. Por um lado, as punições previstas para os governadores que não seguirem os limites e regras estabelecidos na LRF vão de cassação de mandato à prisão. Por outro, a definição não precisa do que seria despesa com pessoal, por exemplo, acaba gerando incentivos para que os governadores aumentem seus gastos sem serem punidos pela lei. Além disso, há a tese de que os controles institucionais foram relaxados no período do pós-crise, em 2008, como uma política anticíclica e que incentivaria a manutenção da atividade econômica dos estados.

O objetivo deste trabalho é identificar, dentro deste espaço institucional de incentivos, qual seria o resultado líquido: os mecanismos institucionais que hoje existem são capazes de impedir o comportamento de risco moral dos estados, e a crise que se percebe teria caráter plenamente cíclico, ou os estados seguem uma política fiscal não sustentável, engrampando os mecanismos institucionais que deveriam limitá-los, e a atual crise seria uma manifestação da insuficiência destes mecanismos.

É importante notar que, sendo um problema de risco moral e que os mecanismos institucionais são insuficientes para punir os agentes, a tendência é que haja sucessivas renegociações ao longo do tempo. Estas renegociações implicariam em um custo elevado para a União e, por consequência, para toda a população brasileira, posto que direcionaria parte do montante arrecadado, que poderia ter como fim áreas de real interesse da população, para sustentar estados que estariam, sistematicamente, tocando sua política fiscal de forma irresponsável e insustentável. Além disso, os investidores considerariam em suas expectativas as constantes renegociações da dívida pela União e o custo destas operações. Passariam a demandar uma taxa de juros maior para adquirir os títulos federais, com os efeitos negativos já discutidos sobre a economia brasileira.

Para verificar a sustentabilidade da trajetória da dívida dos estados, vale-se da metodologia de Bohn (1998), adaptada para dados em painel. Estima-se a função de reação fiscal, cuja intuição é a de verificar se, para um dado aumento no nível da 
dívida, os estados reagem gerando superávit primário significante. A estimação da função de reação fiscal considera a dívida consolidada líquida e dívida consolidada bruta. Ao todo, são estimados cinco modelos: painel completo, separação geográfica, separação por critérios endógenos baseados em Mendoza e Ostry (2008), separação pelos limites de gastos com pessoal da LRF e separação pelo limite de endividamento da LRF. Em cada um destes modelos, a estimação considera quatro recortes temporais: 2001 a 2015, 2008 a 2015, 2001 a 2020 e 2008 a 2020. A ampliação da amostra até 2020 é possível a partir do Anexo de Metas Fiscais, publicado na Lei de Diretrizes Orçamentárias de cada estado.

Identificou-se que, considerando o período 2001 a 2015, os estados seguiram uma política fiscal sustentável. No entanto, para o período de 2008 a 2015 e 2008 a 2020, a trajetória da dívida estadual não foi sustentável, o que corrobora a tese de que os controles ao endividamento foram relaxados após a crise de 2008. Identificou-se também que os limites da LRF, tanto de endividamento quanto de gastos com pessoal, não geram equilíbrios separadores. Estados que ultrapassariam os limites da LRF seguiriam uma política fiscal não distinta daqueles estados que não estão constrangidos por nenhum limite ou punição. Logo, há estados que não seguem uma política fiscal sustentável que não estão sujeitos à nenhuma punição da LRF, tanto nos limites de gasto com pessoal quanto nos limites ao endividamento. Infere-se, portanto, que estes mecanismos não seriam capazes de controlar o comportamento de risco moral, com as consequências descritas acima.

Esta dissertação divide-se em seis seções. A primeira introduz. A segunda objetiva realizar uma discussão histórica e institucional mais aprofundada. A terceira apresenta a revisão da literatura sobre o tema. A quarta apresenta a metodologia de Bohn (1998) para dados em painel. A quinta seção apresenta os resultados. A sexta e última seção conclui. 


\section{ANÁLISE HISTÓRICA DO ENDIVIDAMENTO ESTADUAL}

Neste capítulo, será feita uma análise histórica do processo de endividamento dos Estados, bem como das iniciativas institucionais desenvolvidas à época como forma de sanar as contas públicas, quando se fez necessário. Assim, este será dividido em três seções, antes e depois da Lei de Responsabilidade Fiscal, e o acordo de renegociação das dívidas de 2016.

\subsection{ANOS $1960-2000$}

A década de 60 ficou marcada, politicamente, pelo início da ditadura militar. Como apontado em Mora (2002), o governo militar era fortemente centralizador, especialmente quanto à tributação. O Programa de Ação Econômica do Governo (PAEG) teve como marcas a Reforma Tributária de 1966, que consolidou a concentração tributária, e a Reforma Administrativa de 1967, que buscava dar maior importância à Administração Indireta, especialmente pelas empresas públicas. Dessa forma, estas reformas implicaram em perda da autonomia estadual no aspecto fiscal.

A solução encontrada pelos estados, como aponta Lopreato (2000), foi a de se voltar ao mercado de crédito internacional e doméstico, intermediados principalmente pelos bancos estaduais. A consequência desse fenômeno foi o aumento do endividamento dos estados, em detrimento da poupança fiscal de forma a realizar seus gastos.

Como nota Lopreato (2000), ainda que houvesse, à época, controle ao endividamento, como resoluções do Senado Federal de 1968 e 1970, estes, na prática, serviram para direcionar os recursos a investimentos tidos como produtivos pelo presidente, não para impedir o acesso a novas operações de crédito. Isto fica claro na Resolução n.62 e n.93 do Senado Federal, de 1975, que apesar de fixarem limites máximos da dívida consolidada interna e do gasto anual com a dívida, permitiam a contratação de operações de crédito além dos limites legais, desde que solicitadas ao Senado Federal e aprovadas pelo presidente. 
Fica nítido que, à época, as formas de controle ao processo de endividamento não tinham como objetivo a eficiência, transparência e sustentabilidade da trajetória da dívida. Objetivavam apenas o controle político dos estados pela União. O resultado foi o crescimento do endividamento dos estados após efetivada a legislação que deveria controlá-lo.

$\mathrm{Na}$ década de 80 , este cenário chega ao fim pelas mudanças externas. $\mathrm{O}$ segundo choque do Petróleo atinge a economia brasileira, que se submete à ajustes fiscais estipulados pelo FMI. A Resolução 831 de 1983, como posto em Mora (2002), impôs limites nominais (tetos) ao crescimento do financiamento do setor público realizado em instituições domésticas, o que afetou indiretamente os estados. A reação legislativa, manifesta pela Resolução n. 94 de 1989, do Senado Federal, pouco alterou a resolução n. 93, de forma que o controle efetivo do endividamento foi aquele proposto pelo Banco Central (Lopreato, 2000).

Os estados ficaram, desta forma, em situação sensível. O ajuste fiscal implicou em diminuição da atividade e da arrecadação tributária, redução nas transferências federais, e havia limites às operações de crédito, implicando escassez de receitas. Foi este o cenário até o fim do período militar.

A redemocratização buscou consolidar, politicamente, a institucionalização do aspecto descentralizador da Federação em torno da União, buscando dar mais autonomia política e fiscal para os demais entes da Federação. Para os estados, isto implicava em aumento relativo nas receitas tributárias, como parte do Imposto de Renda e Imposto sobre Produtos Industrializados, e de transferências governamentais.

No entanto, como nota Lopreato (2000), o momento de aumento da importância política dos estados favoreceu o afrouxamento das regras de endividamento, processo que, levado a cabo novamente pelos bancos estaduais, atendeu parte dos problemas de caixa dos estados, sendo responsáveis por $46 \%$ do total de empréstimos concedido a estados e municípios.

No entanto, a crise da década de 80 ainda persistia. Os Bancos Estaduais, pela natureza de suas operações, estavam patrimonialmente vinculados ao desequilíbrio das finanças estaduais. Politicamente, no entanto, a importância dos governadores foi tamanha que o Governo Federal cedeu em negociar as dívidas que os Estados 
possuíam. Assim, como observa Lopreato (2000), os Estados fugiram às restrições financeiras e sustentaram seus gastos, garantindo a sobrevivência de órgãos, empresas e bancos estatais.

Em 1989 ocorre a primeira rodada de refinanciamento da dívida estadual. O Banco do Brasil foi autorizado a refinanciar, pelo prazo de 20 anos, a dívida junto ao Tesouro Nacional relativa ao pagamento da dívida externa e parte das operações internas, de forma a socorrer as finanças estaduais. Não considerou a dívida mobiliária, que corresponde àquela representada por títulos emitidos pela União, dívida com entes do próprio estado e as demais contratações internas, de forma que, ainda após a renegociação, as finanças estaduais permanecem em situação delicada.

Neste mesmo ano, ocorre a vinculação dos títulos estaduais à taxa de rendimento do overnight. Assim, ocorreria o crescimento da dívida mobiliária quando a taxa de juros aumentasse.

Assim, a década de 90 inicia com o aumento da dívida dos estados, dados os altos juros e inflação e os problemas de receita.

O governo Collor preocupou-se em frear o acesso a novos financiamentos e criar regras de controle aos bancos estaduais. A Resolução 1469 do Banco Central, de 1990, visava atacar o primeiro problema, mas esbarrou na pressão dos governadores, pois não estabelecia como contingenciamento de crédito as operações de antecipação de receitas orçamentárias (ARO), operação de crédito que estava ao alcance dos governadores sem que fosse necessária autorização legislativa. $O$ segundo problema foi tratado pela compra pelo Banco Central dos títulos estaduais por outros de sua emissão, de forma a reduzir os custos estaduais com o carregamento da dívida, com a contrapartida de os estados não emitirem novos títulos além da rolagem de $88 \%$ da dívida. Posteriormente, em 1993, foi aprovada a lei n. 8.727, que permitiu o refinanciamento por 20 anos das operações de crédito contratadas junto a instituições financeiras federais.

Como nota Lopreato (2000), por não tratar da dívida pública mobiliária, das operações de ARO e as dívidas com instituições privadas, a solução foi apenas parcial. 
Dessa forma, a dívida estadual continuou crescendo, puxada principalmente pela dívida mobiliária que, como apontado em Mora (2002), crescia a $21 \%$ ao ano e representava, em 1996, 57\% da dívida interna. A dívida mobiliária crescia pela capitalização dos juros ao principal e pela política monetária federal da época. Independiam, portanto, da ocorrência de déficits primários estaduais. A dívida bancária, que também cresce no período, se dá principalmente pelas operações de ARO.

O ano de 1994 é marcado pela implantação do Plano Real e a posterior atenuação do processo inflacionário. No entanto, é sabida a importância do imposto inflacionário como fonte de receita pública, fenômeno conhecido como efeito Tanzi "às avessas", e o encerramento deste processo implica na redução de receitas. A consequência desta interrupção é o aumento, pelos Estados, das operações de ARO, que atingem seu valor mais elevado em 1995. Os bancos públicos sofrem uma crise de iliquidez (Giambiagi e Rigolon, 1999).

A nova equipe de política econômica federal passa a defender novas medidas para superar a crise estadual. É promulgado, assim, o Programa de Ajuste Fiscal e Reestruturação Financeira dos Estados, formalizado na lei 9.496, de 1997. Este programa vinculava o auxílio financeiro federal à reforma do setor público estadual. Desta forma, os Estados que participassem deveriam fixar metas de ajuste fiscal e saneamento financeiro, gerando um superávit operacional superior ao valor de comprometimento da receita líquida real mensal, reduzindo gastos com pessoal, recorrendo à privatização e à concessão de serviços públicos para atingi-las. O auxílio federal era garantido pelo pagamento de $20 \%$ da dívida à vista, estabelecendo-se assim taxas de juros mais baixas. $O$ custo desta operação para o governo federal, de acordo com Mora (2002), foi de R 132 bilhões.

Nota-se, portanto, uma diferença da renegociação das dívidas estaduais ocorrida em 1993 para a ocorrida em 1997. Nesta última, a imposição de metas fiscais e ajustes estruturantes era condicional ao auxílio federal, enquanto a renegociação de 1993 não fixou metas para as operações de ARO, bem como para a dívida pública mobiliária.

Como aponta Mora (2002), a lei também estabelecia que, enquanto a dívida fosse superior à sua Receita Líquida Real, o Estado não podia emitir títulos e a 
contratação de novos empréstimos no exterior dependeria das metas de trajetória da dívida.

Para enfrentar a questão dos Bancos, a medida adotada foi a do PROES (Programa de Incentivo à Redução do Setor Público Estadual na Atividade Bancária), que criava linhas de financiamento a serem usadas na renegociação das dívidas dos bancos estaduais, enquanto se preparavam para a privatização, extinção ou transformação em instituições não financeiras ou agências de fomento.

A lei consegue, dessa forma, atacar o problema da dívida mobiliária estadual, algo que as iniciativas anteriores não conseguiram. Quanto a ARO e sua manifestação sob dívida bancária, observa-se a implementação do Voto CMN 165, de 1995, que autorizava a concessão de empréstimos externos aos estados para a liquidação das ARO, e transformava a dívida de curto prazo em dívida fundada, com menor taxa de juros, aliviando o fluxo de pagamento estadual. É também de 1995 a lei Camata, que estabeleceu limites para a União, estados e municípios para o gasto com pessoal. Posteriormente, seus dispositivos foram incorporados pela lei de Responsabilidade Fiscal.

Todas estas medidas implicaram na redução das opções de atuação estatal na sua condução fiscal. Sobretudo num contexto de baixo crescimento da economia brasileira, os governadores passaram a buscar recursos adicionais, seja revisando acordos de negociação das dívidas ou pela disputa entre entes pela distribuição dos recursos tributários (guerra fiscal). Naturalmente, estes impedimentos à política fiscal, associados ao baixo crescimento da economia verificados à época, implicaram em redução do resultado primário, e posterior aumento na dívida consolidada estadual, como notam Rigolon e Giambiagi (1999).O então governador Itamar Franco chegou, à época, decretar a moratória da dívida do estado de Minas Gerais enquanto buscava na Justiça a derrubada do acordo feito. No entanto, não obteve êxito e continuou a pagar as parcelas da dívida. Neste ponto, como afirma Rigolon e Giambiagi (1999), o dinamismo da economia local é um fator que diferencia o quão crítico estaria a situação de cada Estado.

Para Giambiagi e Rigolon (1999), o governo federal não necessariamente deveria ser ente passivo neste processo de crise fiscal dos Estados. Algumas concessões poderiam ser feitas sem que se prejudique o processo de ajuste fiscal, 
como a redução da meta de resultado primário na ordem de $1 \%$ do PIB para $0,4 \%$, de forma que ainda esteja de acordo com o que prescrevia o FMI. Para os Estados, os autores consideram válidas as políticas de redução dos gastos correntes e a elevação compensatória de outras receitas, como por exemplo as de caráter previdenciário.

\subsection{A LEI DE RESPONSABILIDADE FISCAL E OS ANOS SEGUINTES}

Foi editada, em 4 de maio de 2000, a Lei Complementar n. 101, conhecida como Lei de Responsabilidade Fiscal, que trouxe como princípios o planejamento, transparência, responsabilização e controle dos gastos públicos.

Para Mora (2002), a Lei de Responsabilidade Fiscal estabeleceu regras, limites e controles para uma ação planejada, preventiva e transparente nos três níveis de governo, evitando situações de déficit potencial, garantindo a sustentabilidade do endividamento, sendo uma integralização daquilo que já vinha sendo feito, como PROES, Lei 9.496 e a Lei Camata.

Para tal, estabelece limites para diversos agregados macroeconômicos e instrumentos de política fiscal. Se tais limites não forem obedecidos, o ente não poderá receber transferências voluntárias e contratar operações de crédito, exceto as destinadas ao refinanciamento do principal atualizado da dívida mobiliária. Ao governante as punições podem chegar à cassação do mandato e reclusão até quatro anos.

Um dos limites estabelecidos é o de despesa com pessoal, herdado da Lei Camata, de 1995. O limite estadual é de $60 \%$ da Receita Corrente Líquida (RCL), sendo fracionado pelos demais poderes e Ministério Público. A distribuição, em relação à $R C L$, é de $49 \%$ para o poder executivo, $3 \%$ para o poder legislativo, $6 \%$ para o poder judiciário e $2 \%$ para o Ministério Público. O controle é exercido com auxílio do Tribunal de Contas do Estado, que analisa os limites individualmente, havendo punições impostas gradativamente a partir do momento em que a despesa com pessoal ultrapassa $90 \%$ do valor máximo para cada poder, caso do limite de alerta, $95 \%$ e $100 \%$, casos dos limites prudencial e máximo. 
O gasto com pessoal, considerando servidores ativos e aposentados, ao fim de 2017, era distribuído conforme o gráfico abaixo:

Gráfico 1 - Relação consolidada do gasto com pessoal como proporção da receita corrente líquida dos estados brasileiros

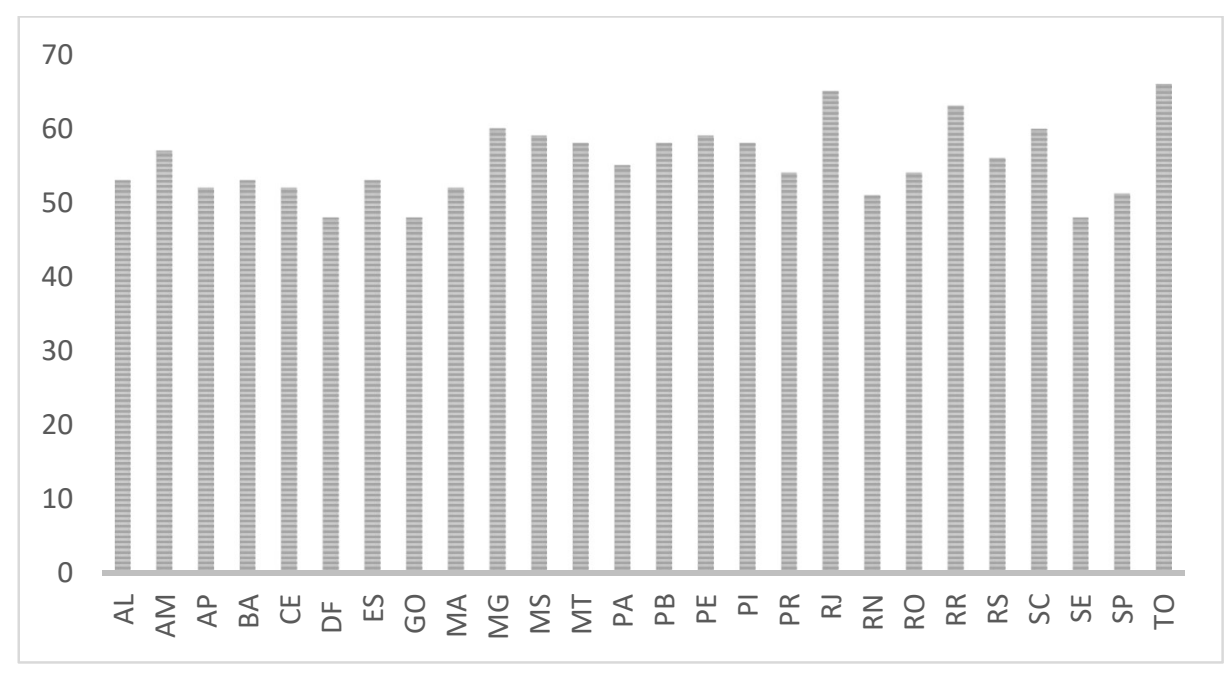

Fonte: Elaboração própria com dados dos Relatórios de Gestão Fiscal

Nota-se que, considerando todos os poderes somados, os estados do Rio de Janeiro, Roraima e Tocantins ultrapassam o limite total de gasto com pessoal. $O$ estado de Minas Gerais está exatamente no limite. Estados como Santa Catarina, Mato Grosso do Sul e Pernambuco também estão perto de alcançar o limite dos gastos com pessoal.

No entanto, os Tribunais de Contas consideram os limites individualmente. Sendo assim, o limite máximo, prudencial e alerta são, respectivamente, 49\%, 46,55\% e $44,1 \%$ da receita corrente líquida. Se dado estado ultrapassar o limite de alerta, apenas, não será constrangido por nenhuma punição, sendo apenas alertado pelo Tribunal de Contas estadual de que se aproxima dos limites mais gravosos. Se ultrapassar o limite prudencial, o estado será proibido de conceder reajustes salariais, exceto os de determinação legal, bem como impedido de criar cargo ou função, contratar pessoal a qualquer título, ressalvada a reposição decorrente de aposentadoria ou falecimento de servidores das áreas de educação, saúde e segurança, havendo também a proibição de contratação de hora extra, salvo no caso de convocação extraordinária da Assembleia Legislativa e demais situações expressas na lei de diretrizes orçamentárias. Por fim, se ultrapassado o limite máximo, o percentual excedente deve ser eliminado nos dois quadrimestres seguintes, sendo 
pelo menos um terço logo no quadrimestre subsequente ao da apuração, devendo haver redução das despesas com cargo em comissão e função de confiança e admitindo-se a exoneração dos servidores estáveis e não estáveis.

Ao fim de 2017, a situação dos estados considerando os gastos do poder executivo, o mais significativo, era a expressa na tabela abaixo:

Tabela 1 - Relação de gasto com pessoal como proporção da receita corrente líquida para o poder executivo

\begin{tabular}{lrc}
\hline ESTADO & \%RCL & LIMITE \\
\hline AC & $53,8 \%$ & Máximo \\
AL & $46,9 \%$ & Prudencial \\
AM & $47,7 \%$ & Prudencial \\
AP & $42 \%$ & - \\
BA & $43,1 \%$ & - \\
CE & $42,4 \%$ & - \\
DF & $46 \%$ & Alerta \\
ES & $43,3 \%$ & - \\
GO & $39,3 \%$ & - \\
MA & $42,4 \%$ & - \\
MG & $50 \%$ & Máximo \\
MS & $48,99 \%$ & Prudencial \\
MT & $47,7 \%$ & Prudencial \\
PA & $45 \%$ & Alerta \\
PB & $46,80 \%$ & Prudencial \\
PE & $48,9 \%$ & Prudencial \\
PI & $47,7 \%$ & Prudencial \\
PR & $45,1 \%$ & Alerta \\
RJ & $61 \%$ & Máximo \\
RN & $41,23 \%$ & - \\
RO & $43,3 \%$ & - \\
RR & $47,7 \%$ & Alerta \\
RS & $46,6 \%$ & Alerta \\
SC & $49,7 \%$ & Prudencial \\
SE & $46,90 \%$ & Prudencial \\
SP & $43 \%$ & - \\
TO & $50 \%$ & Máximo \\
\hline
\end{tabular}

Fonte: Elaboração própria com dados dos Relatórios de Gestão Fiscal

Os estados com situação mais gravosa sob o aspecto de despesas de pessoal, considerando o poder executivo, são Acre, Minas Gerais, Rio de Janeiro, Santa Catarina e Tocantins. São estados que devem eliminar este excesso nos dois quadrimestres seguintes. No entanto, estes prazos podem ser duplicados, em caso de crescimento real do Produto Interno Bruto nacional ou estadual negativo por 
período igual ou superior a quatro trimestres, ou suspensos, na ocorrência de calamidade pública. Este último caso se aplica ao Rio de Janeiro e Minas Gerais, que declararam o estado de calamidade pública em novembro e dezembro de 2016, respectivamente. Não alcançada a redução no prazo estabelecido, e enquanto perdurar o excesso, o ente não poderá: obter garantia, direto ou indireta, de outro ente, contratar operações de crédito, ressalvadas as destinadas ao refinanciamento da dívida mobiliária e as que visem à redução das despesas com pessoal; receber transferências voluntárias, ressalvadas as relativas a ações de educação, saúde e assistência social. A LRF estabelece como sanções possíveis, aos governantes que não obedecerem às punições, a perda do cargo, inabilitação para emprego público, multa e prisão.

É importante notar que Mato Grosso do Sul declarou uma despesa com pessoal de $48,99 \%$, isto é, com uma diferença de $0,01 \%$ do limite máximo. Como será exposto posteriormente, a definição de gastos com pessoal não é precisa. Logo, seria possível que o Mato Grosso do Sul, bem como os demais estados, tenha declarado um valor inferior ao real para não sofrer punições mais severas.

Segundo a Resolução de número 40 do Senado Federal, a relação dívida consolidada líquida e receita corrente líquida dos estados deve ser menor que $200 \%$. Posteriormente, ao analisarmos os modelos empíricos que testam a sustentabilidade da dívida como Bohn (1998), veremos que, na função de reação fiscal, a variável dependente é a série da dívida, no entanto a variável independente é o resultado primário, e não a receita corrente líquida. São indicadores, ainda que distintos, interdependentes. A receita corrente líquida é o total de receitas tributárias, patrimoniais, agropecuárias e demais receitas correntes, deduzidas, para os Estados, as parcelas entregues aos Municípios por determinação constitucional. O resultado primário, por sua vez, é a diferença entre a receita corrente líquida e as despesas correntes, não computadas as despesas de caráter financeiro. A evolução recente do total da receita corrente líquida a preços correntes para os estados brasileiros é apresentada abaixo. À preços correntes, há crescimento da receita corrente líquida no período tratado, com exceção do ano de 2017, em que, mesmo em valores nominais, houve redução da receita corrente. Como será exposto posteriormente, em valores reais, a redução ocorre antes. 
Gráfico 2 - Receita corrente líquida dos estados a preços correntes

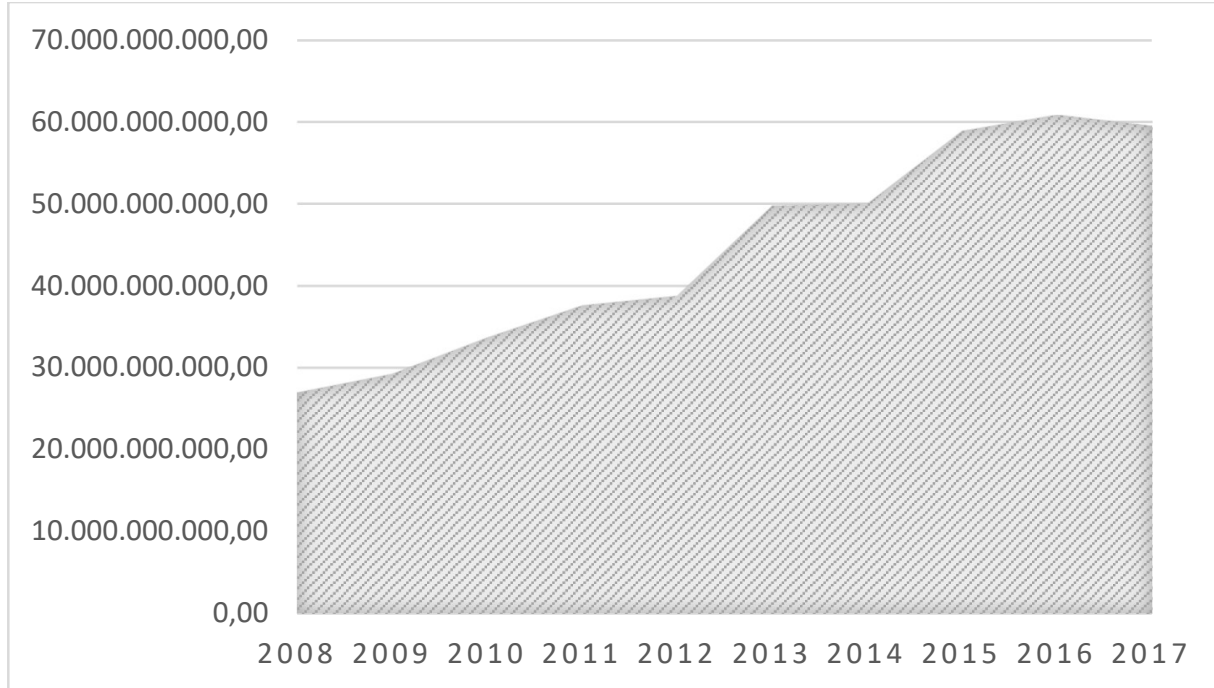

Fonte: Elaboração própria com dados da Secretaria do Tesouro Nacional

Sobre contratação de operações por ARO, estas devem corresponder a até $7 \%$ da Receita Corrente Líquida, e o pagamento de serviços da dívida, 11,5\% da receita corrente líquida. A penalidade do ente que não obedecer a estes limites, além da proibição da realização de crédito interna e externa, é o de obter resultado primário necessário à recondução da dívida ao limite, promovendo, entre outras medidas, limitação do empenho (Art. 31, caput da LRF).

Há ainda mais limites, como de renúncia de receitas, de geração de despesas, de geração de despesas de caráter continuado, inscrição em restos a pagar, dentre outros.

Nota-se que a lei reforça a ideia de que a autonomia fiscal do governador de Estado está circunscrita à arrecadação tributária, o que implica em aumento nos impostos após a sua implementação (Bender e Nakaguma, 2006).

Durante a primeira década dos anos 2000, como nota Piancastelli e Boueri (2008), houve melhora nos resultados primários. A receita tributária dos Estados, em proporção ao PIB, aumentou de $7 \%$ para $8,2 \%$, com aumento de $1 \%$ da arrecadação do ICMS. Como observado em Bender e Nakaguma (2006), houve redução das despesas com pessoal no período. No entanto, houve aumento das despesas de custeio, que não possuem limites estabelecidos na Lei de Responsabilidade Fiscal. Para Estados como Rio de Janeiro e Espírito Santo, a exploração de petróleo contribuiu positivamente para os agregados macroeconômicos. $O$ gráfico com a série 
de endividamento médio bruto e líquido, para os anos 2001 a 2015, consta abaixo. De forma a facilitar a visualização, cabe lembrar que a dívida consolidada bruta é sempre maior ou igual à dívida consolidada líquida.

Gráfico 3 - Dívida consolidada bruta (DC) e dívida consolidada líquida dos estados (DCL) - 2001:15

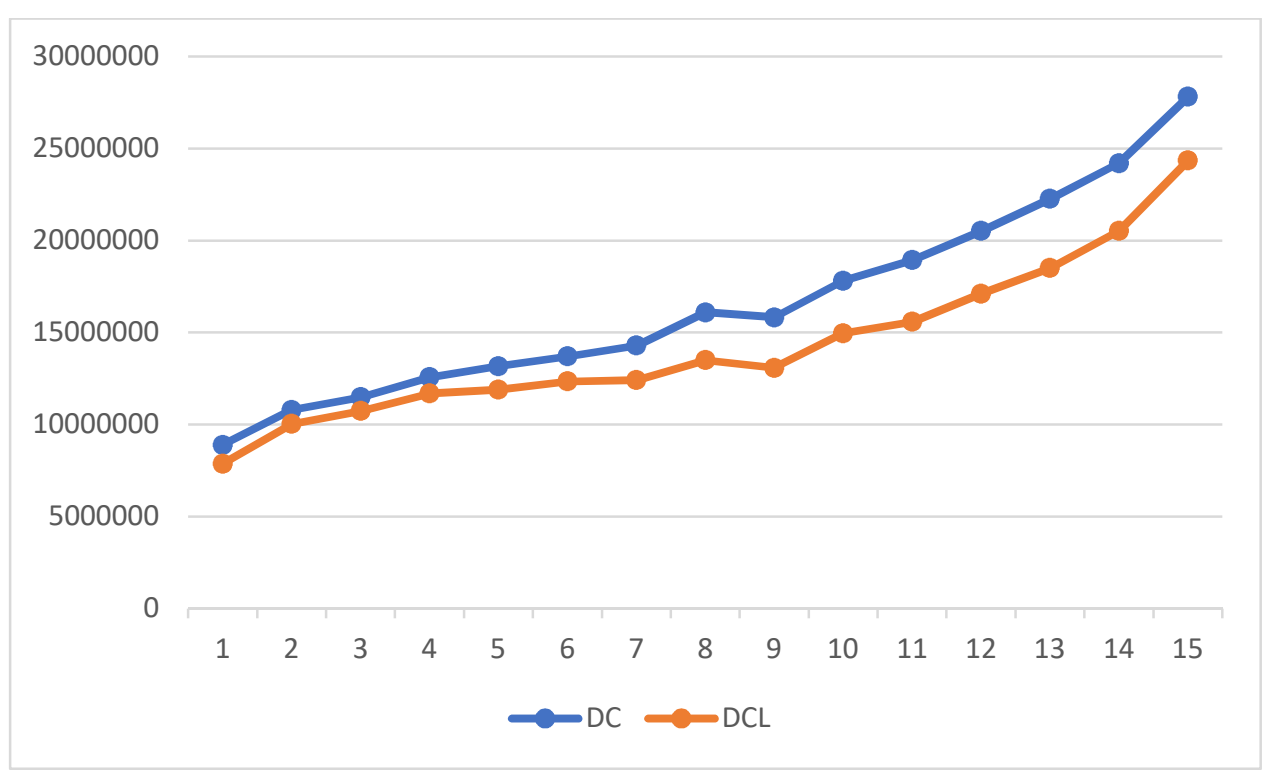

Fonte: Elaboração própria com dados da Secretaria do Tesouro Nacional

Nota-se que, de fato, até o ano de 2007 a trajetória das dívidas segue um processo de breve crescimento anual. O ano de 2008 é marcado pela crise mundial, que trouxe um desincentivo às atividades econômicas e com isso forte efeito recessivo sobre a atividade econômica, com efeito negativo sobre a arrecadação fiscal. No gráfico, há um pico na trajetória das duas dívidas, mas em 2009 elas voltam a cair, em média, já com a estratégica anticíclica federal resultando na retomada da atividade econômica. A partir de 2010, as dívidas começam a crescer de forma mais acelerada do que nos anos anteriores, dado que a inclinação da reta a partir deste ano é maior que a dos anos passados.

Este processo de crescimento da dívida a partir de 2010 marca o momento em que o controle às operações de crédito foi afrouxado, como consequência para os Estados das desonerações fiscais realizadas no período, segundo Velloso (2015). O Governo Federal favorecia a realização de empréstimos para os Estados de forma a manter a economia aquecida. No gráfico 3 é possível perceber que a diferença entre as duas trajetórias se acentua a partir de 2008. Isto se deve à maior disponibilidade 
de caixa dos Estados pelo maior acesso destes ao mercado de crédito. As desonerações, no entanto, prejudicaram a arrecadação estatal. Um dos impostos desonerados foi o Imposto sobre Produtos Industrializados (IPI). A União repassa aos estados o arrecadado com o IPI e Imposto de Renda através Fundo de Participação dos Estados. Este repasse teve um comprometimento de 12,4 bilhões de reais até 2014, segundo a Confederação Nacional dos Municípios. Este processo de afrouxamento das restrições se encerrou em 2015, coincidindo também com a manifestação mais intensa da crise econômica, que representou redução das receitas dos Estados, como mostra a tabela abaixo.

Gráfico 4 - Receita corrente líquida total dos estados a preços de 2008

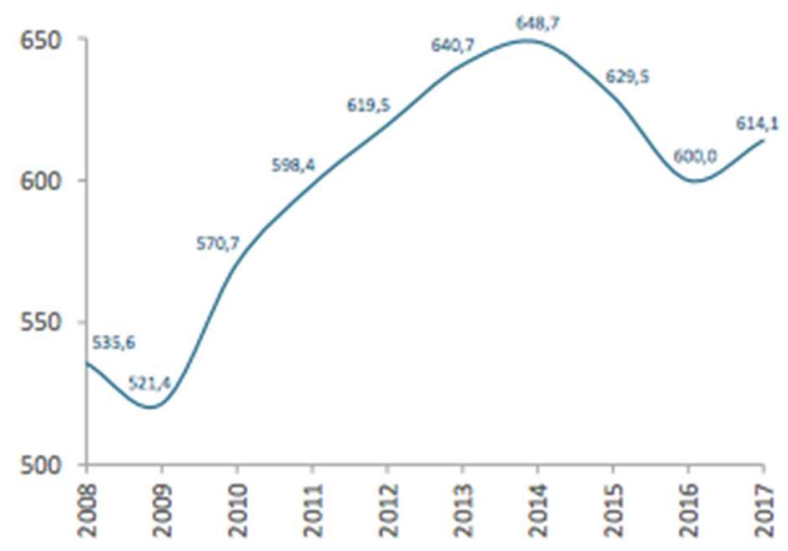

Fonte: Mora, et. al (2018)

É possível notar, no gráfico acima, a redução das receitas correntes reais a partir do ano de 2014, como reflexo do desaquecimento da economia. A redução da receita corrente acaba por limitar o espaço fiscal dos Estados e favorece o processo de endividamento.

Estes recursos advindos de empréstimos, segundo Velloso (2015), serviram para ampliação de gastos com pessoal, e não para investimentos. De fato, o aumento real dos gastos com pessoal dos estados após a crise de 2008 até 2015 foi de $40 \%$. A Lei de Responsabilidade Fiscal, como já vimos, estabelece limites para despesas com pessoal. No entanto, não estabelece o que são despesas com pessoal, permitindo um comportamento discricionário por parte dos Estados. Segundo Maciel (2016), os Estados passaram a alterar a maneira de computar os seus gastos com pessoal, de forma a, artificialmente, cumprir o limite e não ser punido pela Lei de Responsabilidade Fiscal. Esta distorção foi notada a União, mas a tentativa de corrigi- 
la a partir da definição precisa do que seriam gastos com pessoal foi rejeitada pelos deputados federais. Analisando a evolução da despesa com pessoal, considerando apenas o poder executivo, percebe-se aumento significativo ao longo dos anos, aumento este que poderia ser ainda superior se computados aqueles gastos que acabaram sendo considerados despesas de custeio pela ambiguidade da definição.

Gráfico 5 - Despesa com pessoal estadual consolidada do poder executivo

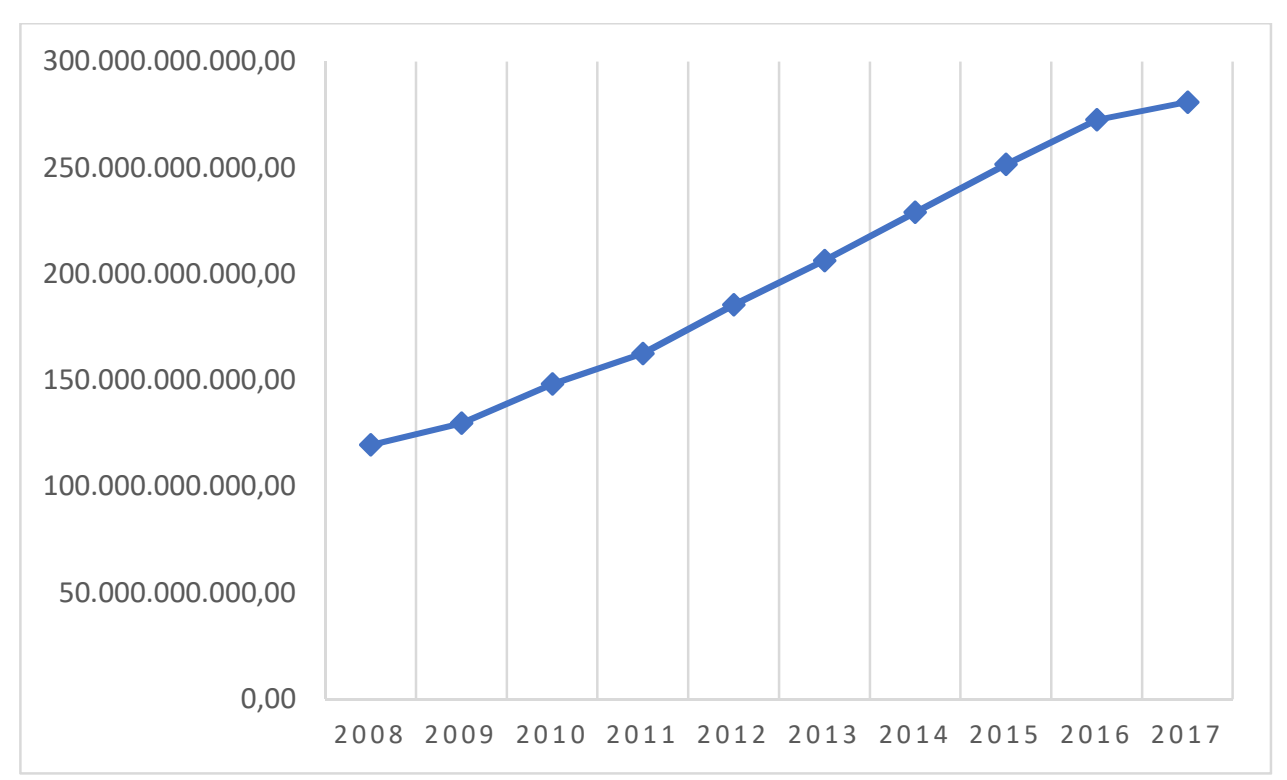

Fonte: Elaboração própria com dados da Secretaria do Tesouro Nacional

Uma questão que é colocada quando analisado o crescimento dos estados com gasto com pessoal, é que ele é relativamente fixo. Se os estados tinham dificuldade em realizar a sua política fiscal apenas com as receitas tributárias e transferências, o aumento de gastos com pessoal acaba por agravar este problema, pois estas despesas são rígidas. Se houver contratação de pessoal a partir do regime estatutário de servidores públicos, como é o caso da Administração Direta, autarquias e fundações, pode-se chegar à situação em que seja necessária a exoneração de servidores já estáveis, um processo burocrático e que demanda ainda mais gastos com as necessárias indenizações.

De fato, pode-se observar que há dispositivos institucionais que permitem que entes federativos tomem posições que seriam distintas daquelas que buscam a máxima eficácia dos gastos públicos. Por exemplo, se por suposto há uma frustração de receita, no sentido de que aquilo que se esperava arrecadar será reduzido, pela Lei de Responsabilidade Fiscal, cabe ao Poder Federativo, em ato próprio, promover 
a limitação nos gastos. Isto é, o Poder Executivo nada pode fazer diante de um quadro em que o Poder Legislativo se depare com uma frustração de receita e não limite seus gastos.

Outro exemplo, é que a limitação dos gastos não poderá ser realizada sobre investimentos que constem na Lei de Diretrizes Orçamentárias. Digamos que certo governador tenha muito interesse em construir uma ponte, ainda que não seja algo essencial para o Estado e, portanto, ele inscreve a construção da ponte na LDO. Então a construção da ponte não será alvo de redução de despesas caso seja preciso para que se atinja a meta de resultado primário, como afirma a LRF.

Por fim, note que a concessão de empréstimos é autorizada pelo Senado Federal. Mora (2002) considera isto uma distorção por questionar se seria o órgão mais capaz, tecnicamente. Seria um julgamento político. Durante parte da segunda década dos anos 2000, o Senado delegou esta função ao Ministério da Fazenda. Se por um lado, a decisão do Ministério seria mais legítima por se tratar de órgão tecnicamente capaz, por outro lado amplia-se a capacidade de o Poder Executivo implantar seu programa econômico com um menor controle do legislativo, aproximando-se inclusive ao processo vivenciado na década de 60. De fato, esta delegação dificultou o controle dos empréstimos concedidos aos entes estatais. Assim, diante da crise de receitas e aumento dos gastos com pessoal, juros e encargos da dívida, os Estados acabaram por pressionar a União para que houvesse nova renegociação das dívidas.

\subsection{A NOVA RENEGOCIAÇÃO DAS DÍVIDAS ESTADUAIS: UM PROBLEMA DE RISCO MORAL?}

Em 2014, após forte pressão dos estados, foi aprovada a Lei Complementar de número 148, que alterou o cálculo das divisas dos estados, com queda nos juros devidos e mudança no indexador. O refinanciamento foi aprovado no fim de 2016, através da Lei Complementar de número 156, e a dívida foi alongada em 20 anos. Os

Estados estariam isentos de pagar o serviço da dívida até junho de 2018, representando um alívio de $\mathrm{R} \$ 50$ bilhões nas contas estaduais. Como contrapartida, 
os Estados estariam sujeitos a um limite superior de gastos, também conhecida como PEC do Teto dos Gastos.

No entanto, eram previstas pela União uma série de outras contrapartidas que, durante a negociação com os estados, não foram aceitas. Entre elas, estava não conceder vantagem, aumento, reajustes ou adequações de remunerações a qualquer título; elevar alíquotas de contribuição previdenciária dos servidores e patronal ao regime próprio de previdência social; implementar programas de desligamento voluntário e de licença incentivada de servidores e empregados; vedar a edição de leis que concedam ou ampliem incentivo ou benefício de natureza tributária ou financeira; suspender a admissão ou contratação de pessoal, a qualquer título; aprovação de lei de responsabilidade fiscal estadual e maior rigor no tratamento das despesas com pessoal. Nota-se que houve o diagnóstico de que o problema fiscal dos estados estaria nos gastos com pessoal, mas não foi possível, politicamente, estabelecer os limites fiscais e legais necessários para estes gastos. Outras exigências iniciais acabaram também dispensadas, como a certidão de regularidade com o Fundo de Garantia do Tempo de Serviço (FGTS) e do Cadastro Informativo de Créditos, também indicativos de natureza fiscal, e a conformidade com dispositivos anteriormente acertados durante as renegociações anteriores também não foi exigida.

A tabela 2 expõe a situação dos estados brasileiros, agregados por região, ao fim de 2017 para as principais variáveis de interesse do modelo a ser estimado: resultado primário (res. primário), dívida consolidada líquida (DC Líquida) e dívida consolidada bruta (DC Bruta). Estas variáveis estão em nível.

Tabela 2 - Valores para o resultado primário, dívida consolidada líquida e bruta para os estados brasileiros ao fim de 2017.

\begin{tabular}{|lrrr|}
\hline 2017 & Res. Primário & DC Líquida & DC Bruta \\
\hline Norte & & & \\
Média & 7.309 & 2.273 .584 & 3.736 .616 \\
Mediana & 16.855 & 2.425 .021 & 3.480 .953 \\
Supremo & 607.215 & 4.322 .558 & 6.203 .245 \\
Ínfimo & -378.200 & 323.845 & 2.123 .874 \\
Nordeste & & & \\
Média & -83.818 & 7.004 .097 & 9.021 .763 \\
Mediana & -49.045 & 6.419 .282 & 7.197 .769 \\
Supremo & 1.046 .549 & 17.229 .304 & 22.677 .718
\end{tabular}




\begin{tabular}{|lrrr|} 
Ínfimo & -1.126 .283 & 1.204 .550 & 2.074 .130 \\
Centro-Oeste & & & \\
Média & -682.329 & 9.821 .044 & 10.844 .600 \\
Mediana & -989.908 & 7.209 .683 & 8.320 .687 \\
Supremo & 739.610 & 19.357 .283 & 19.633 .436 \\
Ínfimo & -1.489 .108 & 5.507 .528 & 7.103 .591 \\
Sudeste & & & \\
Média & -1.615 .973 & 124.844 .453 & 136.923 .043 \\
Mediana & -2.805 .624 & 119.104 .143 & 123.078 .896 \\
Supremo & 5.351 .986 & 259.055 .447 & 294.782 .127 \\
Ínfimo & -6.204 .629 & 2.114 .081 & 6.752 .253 \\
Sul & & & \\
Média & 471.561 & 32.747 .976 & 41.044 .716 \\
Mediana & -422.492 & 10.797 .796 & 23.224 .813 \\
Supremo & 2.970 .670 & 76.703 .155 & 76.703 .155 \\
Ínfimo & -1.133 .494 & 10.742 .977 & 23.206 .180 \\
\hline
\end{tabular}

Fonte: Elaboração própria com relatórios da Lei de Responsabilidade Fiscal.

Percebe-se que os estados são heterogêneos entre si. A região sul é a que apresenta a maior média de geração de superávit primário. No entanto, os seus supremos para a dívida consolidada líquida e bruta são o segundo maior considerando todas as regiões. A região norte, no geral, possui os menores valores, em módulo, se comparada com as demais regiões. A região sudoeste, influenciada pela crise que enfrenta os estados de Minas Gerais e Rio de Janeiro, possui sua média inferior à mediana para o resultado primário, isto é, a maioria dos valores se concentra abaixo da média, que já é negativa. Não fosse São Paulo, o estado que gerou maior resultado primário para o período considerado, esta média seria ainda menor. Os supremos e ínfimos para o resultado primário, dívida consolidada líquida e bruta são apresentados na tabela abaixo:

Tabela 3 - Supremos e ínfimos para o conjunto de variáveis de interesse

\begin{tabular}{|c|c|c|c|}
\hline 2017 & Resultado Primário & DC Líquida & DC Bruta \\
\hline \multicolumn{4}{|l|}{ Norte } \\
\hline Supremo & Amazonas & Amazonas & Amazonas \\
\hline Ínfimo & Amapá & Amapá & Roraima \\
\hline \multicolumn{4}{|l|}{ Nordeste } \\
\hline Supremo & Ceará & Bahia & Bahia \\
\hline Ínfimo & Maranhão & Rio G. do Norte & Rio G. do Norte \\
\hline \multicolumn{4}{|l|}{ C.Oeste } \\
\hline Supremo & Goiás & Goiás & Goiás \\
\hline Ínfimo & M. Grosso do Sul & Mato Grosso & Mato Grosso \\
\hline
\end{tabular}




\begin{tabular}{|llll|}
$\begin{array}{l}\text { Sudeste } \\
\text { Supremo } \\
\text { İnimo }\end{array}$ & $\begin{array}{l}\text { São Paulo } \\
\text { Rio de Janeiro }\end{array}$ & $\begin{array}{l}\text { São Paulo } \\
\text { Espírito Santo }\end{array}$ & $\begin{array}{l}\text { São Paulo } \\
\text { Espírito Santo }\end{array}$ \\
$\begin{array}{l}\text { Supremo } \\
\text { İnfimo }\end{array}$ & $\begin{array}{l}\text { Paraná } \\
\text { Rio Grande do Sul }\end{array}$ & $\begin{array}{l}\text { Rio Grande do Sul } \\
\text { Paraná }\end{array}$ & $\begin{array}{l}\text { Rio Grande do Sul } \\
\text { Paraná }\end{array}$ \\
\hline
\end{tabular}

Fonte: Elaboração própria com relatórios da Lei de Responsabilidade Fiscal.

Desta forma, se observado o processo de endividamento dos Estados a partir da década de 60, é possível notar que os governantes sempre buscaram criar artifícios para expandir o seu espaço fiscal, isto é, de aumentar as suas despesas em um montante superior ao arrecadado por impostos e transferências.

De início, os governantes dos estados contavam com o apoio da União, através de resoluções do Senado Federal, em que as operações de crédito deviam ser aprovadas pelo presidente. No entanto, a crise da década de 80 representou uma mudança na postura da União, que passou a tentar controlar as operações de crédito.

A redemocratização, por sua vez, deu maior importância relativa aos Estados e Municípios. Os governantes estaduais valeram-se deste momento de importância política para negociarem o refinanciamento de suas dívidas. $O$ ônus do processo de endividamento foi assumido pelo governo federal.

Já no início década de 90, o governo Collor tentou criar mecanismos de controle às operações de crédito, mas por pressões políticas, não conseguiu dispor sobre as operações de ARO, que continuaram a serem executadas pelos governadores. Ainda assim, o governo aprovou o refinanciamento das operações de crédito contratadas junto a instituições financeiras federais.

Há uma mudança institucional a partir de 1994, marcada por diversas reformas que inibiram e controlaram as operações de crédito por parte dos Estados. A Lei de Responsabilidade Fiscal é um grande marco deste período. No entanto, a LRF não estabelece limites para despesas de custeio, mas estabelece limites para despesas com pessoal. Houve então forte incentivo de os governantes aumentarem seus gastos, afirmando se tratar de gastos com custeio, dado que a definição de gastos com pessoal na LRF é vaga. Em 2016, o governo do estado de São Paulo declarou que parte dos seus gastos com pessoal inativo seria investimento em educação, possivelmente como forma a escapar dos limites da LRF. As contas do governador 
foram aprovadas pelo Tribunal de Contas para o período. Quando a União tentou definir claramente as despesas com pessoal, impondo limites à admissão e propondo reformas, as pressões políticas estaduais levaram a rejeição da proposta. Concomitantemente a este aumento dos gastos, houve redução do controle das operações de créditos principalmente a partir de 2010, com o interesse de manter a economia aquecida. Este processo levou a uma nova renegociação das dívidas dos Estados, materializado na citada Lei Complementar 156.

Dado o comportamento dos Estados diante das brechas institucionais, pode-se inferir que há um problema de risco moral. Os Estados continuam a se endividar porque sabem que, no limite, o Governo Federal renegociará a sua dívida. Alesina e Tabellini (1990) notam que a dívida de um governo tende a ter um equilíbrio maior quando há maior grau de polarização política, quanto maior a probabilidade de o partido no poder não ser reeleito e quanto mais rígido para baixo for o consumo do governo. Observando o processo de endividamento dos Estados da década de 60, nota-se que sempre foi preferível ter espaço para realizar o gasto público a ter um espaço fiscal circunscrito apenas ao montante arrecadado. Um exemplo da subversão à vontade política da sustentabilidade ocorreu inclusive na renegociação mais recente da dívida dos Estados, em que estes foram dispensados das contrapartidas até então exigidas para o refinanciamento de suas dívidas, que se relacionam à saúde fiscal, creditícia, e de gastos com pessoal, e de que Estados estejam em dia com aquilo que foi estabelecido quando das renegociações realizadas anteriormente. Por outro lado, o Tesouro Nacional buscou estabelecer com os Tribunais de Contas Estaduais um convênio para que todos os estados da federação utilizem os mesmos parâmetros para contabilizar os limites da LRF, cujo início se dará em 2019.

Como observa Bugarin (2004), parte do êxito de uma renegociação da dívida estadual pela União passa por se estabelecer um equilíbrio de reputação por parte dos agentes. Se a União, de maneira crível, se comprometer a reagir de maneira imediata contra aqueles que descumprirem os acordos de renegociação e mecanismos institucionais à forma da lei, então sofrerá um custo político, sopesado pelos benefícios fiscais que obterá futuramente. Por outro lado, se os estados acreditarem que não serão punidos caso desviem de seus acordos de renegociação ou dos mecanismos institucionais, manifestar-se-á o "paradoxo da renegociação das dívidas", em que se reduz o incentivo dos estados em gerar recursos por meio de 
esforço fiscal, recorrendo a moratórias sucessivas das dívidas. Neste caso, o benefício fiscal que surge da punição aos estados não compensa o custo político que esta punição representa para o governante. Este é o caso de uma União que esteja enfraquecida politicamente, e que preferirá renegociar as dívidas estaduais a entrar em um conflito, como ao fim da década de 80 e no início da década de 90 . A popularidade do governo federal após o fim da inflação poderia garantir a vantagem política da União, e logo a credibilidade para os estados de que seriam punidos caso não respeitassem os acordos de renegociação de 1997, que acabou sendo o último em quase duas décadas, o que sugere que a União conseguiu gerar um equilíbrio de reputação.

Logo, por um lado há mecanismos institucionais, como o PROES, a Lei 9.794 e a Lei de Responsabilidade Fiscal, que visam controlar as operações de crédito e o processo de endividamento dos entes estaduais, estabelecendo limites e punições para aqueles que não cumprirem os estabelecidos. Por outro, há o comportamento de risco moral por parte dos governantes dos Estados, que assumem que o custo do endividamento não sustentável recairá apenas sobre a União, sendo o aumento de gastos favorável como forma de garantir sustentação política.

Assim, é preciso verificar se estes mecanismos de controle, em especial a Lei de Responsabilidade Fiscal, de fato são suficientes para que haja uma trajetória sustentável da dívida estadual, mesmo sob o efeito do comportamento dos governantes estaduais, ou se é necessário que haja novas formas de controle, como a definição precisa de despesas com pessoal ou a exigência de contrapartidas mais severas quando houvesse renegociação das dívidas estaduais pela União.

Para verificar empiricamente se a trajetória da dívida estadual é sustentável, será adotado o modelo de Bohn (1998) para os anos após a Lei de Responsabilidade Fiscal, modelo este que será apresentado e desenvolvido em seções posteriores. Antes disso, no entanto, é realizada a revisão da literatura sobre o tema. 


\section{REVISÃO DA LITERATURA}

Neste capítulo, discute-se como a forma de se mensurar a sustentabilidade da trajetória da dívida de um governo evolui ao longo do tempo. Após esta discussão, o foco será na aplicação dos modelos sobre dados internacionais e nacionais, contemplando dados em cross-section, em que apenas um estado ou país é analisado, e dados em painéis, em que o estudo é realizado em um conjunto de estados ou países.

\subsection{LITERATURA SOBRE DADOS INTERNACIONAIS}

O artigo seminal de Flavin e Hamilton (1986) utiliza a metodologia de testes de raiz unitária para as séries de dívida e superávit americanos de 1960 a 1984. A ideia era verificar se estes processos são não-estacionários. Sendo estacionária, a trajetória da dívida então seria equilibrada, posto que seria um indicativo de que o governo persegue uma política ativa de geração de superávit para contrabalancear um eventual aumento da dívida. Isto é, a restrição orçamentária intertemporal do governo ${ }^{2}$ estaria satisfeita. As estatísticas dos testes realizados sobre as séries, incluindo diferentes defasagens para dívida e superávit, indica que estas são estacionárias. Assim, a política fiscal seria sustentável, e os governos não conseguiriam manter déficits contínuos ao longo do tempo, devendo-se comprometer a gerar superávits futuros.

Trehan e Walsh (1988) criticam a abordagem anterior. Destarte, o nível de significância estabelecido anteriormente, de 10\%, seria demasiado leniente. A um nível de 5\% de significância, mais rigoroso, não poderia se rejeitar a hipótese nula de que há raiz unitária para as séries. Além disso, observam que uma amostra de 22 anos teria um baixo poder de teste, peculiar dos testes de raiz unitária. Partem, assim, para uma abordagem diferente. Para eles, a ideia de sustentabilidade de dívida estaria atrelada a ideia de que a trajetória dos gastos do governo, incluindo juros, não poderia

\footnotetext{
${ }^{2} \mathrm{~A}$ apresentação, desenvolvimento e definição da Restrição Orçamentária Intertemporal do Governo será realizada de maneira mais formal no capítulo quatro: metodologia.
} 
se descolar da trajetória da receita (senhoriagem e impostos) deste governo. Isto é, as variáveis devem ser cointegradas, seguindo Engle e Granger (1987) e Engle e Yoo (1987). Com uma amostra de 1890 a 1986, encontram um vetor de cointegração para as variáveis, concluindo assim que a trajetória da dívida americana seria sustentável.

Hakkio e Rush (1991) aplicam a metodologia anterior para as séries americanas de 1950 a 1988. No entanto, dividem a amostra em diferentes períodos para identificar mudanças na condução da política fiscal. Ainda que as receitas e gastos do governo sejam cointegrados para a amostra inteira, o fator de cointegração é menor que 1. A intuição é que há um descompasso entre as receitas e despesas. Isto implica que os gastos do governo crescem mais rapidamente que a sua receita, um efeito que é ainda mais crítico quando se divide a amostra nos anos mais recentes. Isto seria um indicativo de que a política fiscal não seria sustentável.

Bohn (2007) busca demonstrar a razão de as abordagens anteriores: testes de raiz unitária e cointegração, não serem capazes de determinar se a dívida é sustentável, isto é, que a restrição orçamentária intertemporal do governo estaria satisfeita. Demonstra, por exemplo, que é possível que a restrição orçamentária intertemporal do governo (ROIG), seja atendida mesmo que a trajetória da dívida do governo não seja estacionária, contrariando Flavin e Hamilton (1986). Evidencia ainda que, mesmo que gastos do governo e receitas sejam não cointegrados, podendo inclusive possuir diferentes ordens de integração, é possível atender a ROIG, contrariando Trehan e Walsh (1988) e Hakkio e Rush (1991). A principal conclusão é a de que a ROIG, por si só, impõe condições econométricas muito fracas. Bohn então sugere, como alternativa, examinar o comportamento do policy-maker. Isto seria possível a partir da estimação de uma função de reação fiscal, que conseguiria captar como este agente, interessado em respeitar a ROIG, reage, via geração de superávit primário, face a uma variação na dívida de seu país.

Bohn (1998) estima uma função de reação fiscal para uma amostra do estoque da dívida/PIB e superávit primário/PIB americanos de 1916 a 1995. Utilizando superávit/PIB como variável dependente, e a relação dívida/PIB, bem como gasto temporário do governo (gastos militares) e um indicador de business cycle, obtido a partir da utilização do filtro HP sobre o log do PIB, como variáveis de controle. Encontra o resultado de que um aumento marginal na dívida implica em um superávit primário de cerca de $5 \%$ sobre o PIB para o período seguinte. Sendo isto verdade, 
então a política fiscal americana é dita sustentável para o período, ainda que este tenha sido marcado por sucessíveis déficits.

Bohn (2008) amplia a base de dados para 1792 a 2003, mas ainda seguindo o mesmo modelo anterior. Com a base de dados mais ampla, encontra um coeficiente estatisticamente significante da dívida. Logo, um aumento marginal na dívida implicaria em um superávit primário sobre o PIB de cerca de $12,1 \%$ para o período seguinte. É, portanto, um resultado mais robusto que o encontrado anteriormente. $\mathrm{O}$ autor ainda acrescenta alguns parâmetros ao modelo. Primeiramente, acrescenta um componente de tendência ao modelo, que não apresenta significância estatística. Acrescenta também um termo de desvio quadrado da dívida pública em relação à sua média, para captar efeitos de não linearidade na relação superávit-dívida, mas também não encontra significância estatística. Em um outro modelo, altera a forma em que se define os gastos temporários, com dados reais de gastos militares, não alterando o comportamento do modelo. Por fim, omite as variáveis de controle (gastos temporários e o indicador de business cycle). Neste último caso, o coeficiente da dívida é menor em magnitude, análogo a um caso em que há viés de variável omitida.

D’Erasmo, Mendoza e Zhang (2015) estimam a reação fiscal americana para o período de 1971 e 2014. Observam uma queda na magnitude da reação do governo americano, pois dado um aumento marginal na dívida, o superávit primário sobre o PIB para o período seguinte é de $7,8 \%$. Segundo os autores, esta queda reflete uma quebra estrutural da função de reação fiscal, resultado da crise de 2008. Uma forma de verificar que este é o caso é que, truncando a amostra até 2008 , os resultados encontrados são muito próximos ao que encontra Bohn (2008). O teste de Chow formaliza esta hipótese, posto que rejeita a hipótese de que não há quebra estrutural para o período após 2008.

A metodologia de Bohn logo foi adotada para analisar séries que não a americana. Greiner, Köller e Semmler (2007), por exemplo, aplicam a metodologia de Bohn a um conjunto de países ${ }^{3}$, individualmente. Alguma das modificações propostas pelos autores são as de incluir, na função de reação fiscal, os gastos do governo

${ }^{3}$ Os países são Alemanha, França, Itália, Portugal e Estados Unidos, em uma série de 1964 a 2003. A escolha de países europeus é devido ao fato de estes violarem o critério de Maastricht. São países cuja relação dívida/PIB é maior que $60 \%$, ou países cujo deficit primário representa $3 \%$ ou mais do PIB. 
líquidos de juros e um termo da dívida em lag, como variáveis independentes. O resultado encontrado é que a trajetória da dívida é sustentável para os países analisados.

Fincke e Greiner (2011) também aplicam a metodologia de Bohn para países da zona do Euro, mas ampliam a base verticalmente, ao incluir Áustria e Holanda, e horizontalmente, ao estender a série até 2006. A grande diferença é que o coeficiente associado à dívida, o que mede a resposta de um país dada uma variação marginal na dívida, varia com o tempo. Esta análise permite discernir momentos do tempo em que a função de reação fiscal foi mais ou menos responsiva, com a consequente interpretação e analogia com o momento socioeconômico que vivia dado país. Para o grupo de países analisado, a dívida parece ser sustentável, ainda que a função de reação seja mais ou menos responsiva ao longo do tempo.

Burger et al (2011) estima a função de reação fiscal para a África do Sul, para um período de 1974 a 2008. A grande inovação proposta pelos autores é a de estimar a função de reação fiscal a partir de três ângulos. Primeiramente, assumindo que as séries são estacionárias, estimam a função de reação fiscal por mínimos quadrados, VAR e GMM. Depois, consideram que há não linearidade na função de reação fiscal, e então a estimam por modelos de threshold. Por fim, admitem a possibilidade de as séries não serem estacionárias e estimam um modelo de correção de erros. Para todas as estimações, houve resposta positiva do coeficiente de resposta do governo, o que implica que a trajetória da dívida é sustentável. O fato de o paper ter explorado possíveis cenários de estimação e, para todos estes, ter-se garantido sustentabilidade garante robustez ao resultado.

Ainda que a metodologia de Bohn se aplique a um país, é possível adaptá-la para trabalhar em séries em painel, de forma a analisar uma série de países. Mendoza e Ostry (2008) baseiam-se metodologia de Bohn, mas agora para dados em painéis, buscando entender se países mais endividados possuem uma reação fiscal menos "responsiva". Isto é, se essa resposta do policy maker é menos sensível quanto mais endividado seu país é. Para testar esta hipótese, os autores elaboram um painel com países industrializados e emergentes: 22 e 34 países, respectivamente, para os anos de 1970 a 2005. Primeiramente, separam os países pelo seu grau de desenvolvimento para, depois, realizar a análise conjunta. Encontram, para o grupo de países emergentes, uma resposta da função de reação fiscal mais intensa do que a do grupo 
de países desenvolvidos. Países emergentes, assim, seriam mais rigorosos em sua geração de superávit primário do que os países desenvolvidos. Além disso, em cada um dos grupos, países mais endividados possuíam uma reação de menor escala em comparação aos menos endividados (aqueles que possuem uma relação dívida/PIB menor que a média e mediana do painel completo), e este comportamento é significativo a partir de uma relação dívida/PIB de 50\%. Para o painel completo, um aumento marginal na relação dívida/PIB implica em um superávit primário sobre o PIB de $4 \%$ no próximo período para os países com pouca dívida, enquanto para os países com dívida alta, este valor é de $2 \%$.

Ghosh et al (2013) notam, que nem sempre um aumento no superávit em resposta a um aumento marginal na dívida implica em sustentabilidade desta última. Supondo uma dívida suficientemente grande, seria teoricamente possível que apenas um superávit maior que o PIB fosse capaz de equilibrar a relação dívida/PIB dada certa taxa de juros. A esse ponto da dívida em que este comportamento ocorre os autores denominam limite da dívida. Observam que à medida que a dívida cresce, menor é a reação do governo em gerar superávits, fenômeno que denominam fadiga fiscal. Por fim, utilizam o termo "espaço fiscal" para caracterizar a diferença entre o limite da dívida e a relação dívida/PIB projetada para o país. Partem então para a estimação da função de reação fiscal para 23 países, para um período de 1970 a 2003. O limite da dívida e o espaço fiscal varia entre os países. Em situação confortável encontram-se Austrália, Coreia do Sul e países nórdicos. Países do Sul da Europa, quase todos estes analisados como sustentáveis em Greiner, Köller e Semmler (2007), Japão e Islândia são aqueles com menor espaço fiscal e mais vulneráveis a choques em sua trajetória de dívida.

Potrafke e Reischmann (2015) buscam adicionar à estrutura de Bohn as transferências fiscais para um painel composto por Estados Unidos e Alemanha. A ideia era estimar a função de reação fiscal com duas noções distintas de resultado primário: em uma delas, não estariam incluídas as transferências fiscais. Quando analisada a função de reação fiscal com o resultado primário sem as transferências, não se verificou sustentabilidade da política fiscal, enquanto quando estas últimas foram incluídas, o resultado foi o de sustentabilidade, sendo um insight a partir do modelo original de Bohn. 
Aproximando-se mais do tema deste trabalho, Claeys, Ramos e Suriñach (2008) estimam funções de reação fiscal para estados americanos e alemães, cuja estrutura fiscal e institucional os autores consideram equivalentes, consolidando um painel de 1963 a 2000. Encontram significância estatística para estados americanos, mas o mesmo não pode ser dito sobre os alemães. Como visto anteriormente, em nível federal, a dívida alemã é sustentável, mas os estados respondem de outra maneira.

Um estudo focado apenas nos estados alemães é realizado por Fincke e Greiner (2011). Analogamente ao paper de mesmos autores, de 2011 o coeficiente relacionado à dívida pode variar no tempo. A partir de uma base de dados de 1975 a 2006, e considerando apenas os estados da Alemanha Ocidental, pode-se separar os estados em dois grupos, os que têm trajetória sustentável da dívida e os que não possuem. Os autores notam que, até mesmo para o grupo de estados "sustentáveis", com a exceção de um estado, é possível observar que a relação dívida/PIB está aumentando com o tempo, um comportamento que compromete a sustentabilidade de longo prazo.

\subsection{LITERATURA SOBRE DADOS NACIONAIS}

Na sessão anterior, observamos que houve quatro autores que moldaram a metodologia de séries temporais. Primeiro, Hamilton e Flavin (1986), seguidos de Trehan e Walsh (1988), Hakkio e Rush (1991) e Bohn (1998, 2008). Para o caso brasileiro, a literatura consiste na aplicação destes modelos para os dados brasileiros.

Rocha (1997) baseia-se nas séries fiscais brasileiras de 1980 a 1993 para desenvolver dois testes. O primeiro baseia-se em Trehan e Walsh (1988), e se inicia com a análise do processo gerador do estoque da dívida brasileira, com um teste de raiz unitária. Confirmando-se com significância estatística a existência de raiz unitária, parte-se para o teste de raiz unitária para a série da dívida em diferença. Desta vez, rejeita-se a existência de raiz unitária. A série da dívida é integrada de primeira ordem. Passa-se então a um segundo teste, baseado em Hakkio e Rush (1991). A ideia é verificar se as despesas e receitas são cointegradas. A senhoriagem é fundamental 
para que haja cointegração entre as séries, um indício de que, ainda que a dívida seja sustentável, ela se dá devido a um processo que gera constante aumento da base monetária, gerando pressão inflacionária.

Issler e Lima (2000) valem-se da metodologia de Hamilton e Flavin, usando como base os dados brasileiros de 1947 a 1992. Ao considerar senhoriagem como receita do governo, chegam na mesma conclusão que Rocha (1997).

Luporini (2001) aplica a metodologia de Bohn (1998) para as séries fiscais de 1966 a 2000 no Brasil. Os resultados encontrados não indicam que variações na relação dívida/PIB geram respostas sob o superávit primário por parte do Governo. Assim, não se pode afirmar que haveria uma tendência de retorno à média por parte da dívida, e ela não poderia ser definida como sustentável. Nota-se que, portanto, a mudança de metodologia foi suficiente para que o resultado encontrado fosse divergente com os anteriores.

Goldfajn (2002) parte da metodologia de estimar cenários para as variáveis macro, como crescimento real do PIB, resultado primário, depreciação nominal do câmbio e deflator do PIB até 2011. Observa que, mesmo adotando uma visão "pessimista" a respeito de tais variáveis, a relação dívida/PIB irá pelo menos se estabilizar, chegando a decair a depender do cenário estabelecido.

Bicalho (2005) aplica a metodologia de Hakkio e Rush (1991) e Bohn (1998) para séries do setor público consolidado, que compreende, dentre outros, a administrações diretas federal, estaduais e municipais, aos anos de 1997 a 2004. Tanto o teste de cointegração quanto a estimação da função de reação fiscal corroboram a hipótese de que a dívida brasileira seria sustentável para o período. Tal resultado é encontrado também por Mello (2008), que estima a função de reação fiscal para o setor público consolidado, o governo central e governos regionais para um período de 1995 a 2004. O autor observa que a partir de 1998 os governos ficaram mais responsivos à variação marginal da dívida.

O resultado encontrado por Mello (2008) é contrastado por Mendonça (2009). Se, para o primeiro, o governo ficou mais reativo no sentido de gerar superávits primários a uma variação marginal na dívida a partir de 1998, para o segundo a partir de 2000 houve uma piora neste sentido. A diferença pode se dar pelo fato de Mendonça (2009) ter utilizado uma metodologia de Markov-switching em que se 
assume a possibilidade de que, a cada instante do tempo, um número especificado de cenários pode se fazer presente, ainda que não se saiba de antemão qual deles seria. Com base neste método, observam que, para após outubro de 2000, observase uma baixa reação do governo e, antes deste período, era evidente a reação do superávit primário.

Simonassi, Arraes e Sena (2014) estimam, para o período de 1991 a 2008, uma função de reação como propõe Bohn (1998), mas expandem o modelo para estimar quebras estruturais endógenas, seguindo o procedimento de Bai e Perron (1998). Ao longo do período tratado, os resultados indicam sustentabilidade na dívida. São duas as quebras estruturais encontradas. Apenas a partir de maio de 1994 é possível perceber que a resposta do governo à dívida foi eficaz. A segunda quebra, de fevereiro de 2003, sinaliza que a resposta do governo ficou ainda mais forte em gerar superávits dada uma variação na dívida.

Chicoli (2015) vale-se da mesma metodologia anterior, agora utilizando dos dados de 2003 a 2014, mas com um resultado diferente, o de não sustentabilidade. A grande diferença, além do período considerado, está no fato de que desenvolve vários conceitos de superávit para teste. São eles: superávit primário oficial, superávit primário sem contabilidade criativa e o superávit primário permanente, em que se exclui receitas e despesas atípicas do governo federal, dividendos de empresas estatais, refinanciamentos de dívidas, entre outros. Para todos os conceitos de superávit utilizados, não encontra sustentabilidade na trajetória da dívida. Pelos testes de quebra estrutural, encontra que a "alteração da postura fiscal do governo no póscrise foi desfavorável à administração da dívida pública, além de ter grande relevância para os resultados contrários à sustentabilidade obtidos".

Luporini (2015) analisa novamente a questão, utilizando a mesma metodologia de outrora, agora para dados mensais de 1991 a 2011. Em relação aos resultados anteriores, a autora observa que a função de reação se tornou mais estável, mas menos responsiva a variações na relação dívida/PIB a partir de 2000, com uma tendência declinante a partir de 2006, o que está em harmonia com Chicoli (2015). Conclui que, ainda que haja sustentabilidade da dívida/PIB, esta relação é fortemente dependente da taxa de crescimento da economia brasileira. 
Passando da ótica federativa para a estadual, há a contribuição de Silva e Sousa (2002), que buscaram identificar os determinantes do endividamento dos governos estaduais por meio de análise de dados em painel, com dados mensais de 1997 a 2001. Os resultados indicam que, nos estados mais pobres, transferências do setor federal reduzem a dívida estadual, enquanto esta variável não afeta os estados ricos. Gastos com pessoal afetam o grau de endividamento de ambos os tipos de estados, em especial os mais pobres, enquanto gastos de investimento só afeta os estados mais ricos em seu grau de endividamento.

Mora e Giambiagi (2007) fazem uma análise a partir da elaboração de cenários, como em Goldfajn (2002). Seguindo a tendência observada em 2004, concluem que "somente os estados de Alagoas, Goiás, Mato Grosso do Sul, Minas Gerais, Rio Grande do Sul e São Paulo desrespeitavam os limites ao endividamento estipulados pela LRF e devem se ajustar para atingi-los em 2016". Apontam também o descolamento do indexador da dívida dos estados, o IGP-DI, atuando na prática como um fator de aumento da taxa de juros, cujo efeito seria o de diminuir o ritmo de queda da dívida dos Estados no período tratado. A mudança de indexador, como visto, ocorreu na última renegociação.

Pereira (2008) baseia-se em Hakkio e Rush (1991), adaptando-o para dados em painel, para investigar a sustentabilidade das dívidas estaduais. Utilizando uma amostra de 1986 a 2005, realiza testes de raiz unitária para poder aplicar o método de cointegração de Pedroni (2000) e Johansen (1991) para dados em painel. Os resultados para a região Sul e Sudeste apontam que não há cointegração entre receita e despesa corrente, um indicativo de que não haveria sustentabilidade na trajetória das dívidas. Quando consideradas as demais regiões, os resultados são contrastantes, o que impossibilitaria um diagnóstico final. No entanto, a maior parte da amostra analisada é do período anterior à Lei de Responsabilidade Fiscal.

Fontenele, et. al (2015) analisa a sustentabilidade dos 26 estados brasileiros e o Distrito Federal no período de 2000 a 2010, portanto posterior à Lei de Reponsabilidade Fiscal, a partir da metodologia de Hamilton e Flavin (1986). Para tal, realiza testes de raiz unitária para verificar se a trajetória da dívida era sustentável. Com exceção dos estados do Centro-Oeste, todos os outros estados apresentaram uma trajetória de dívida/PIB não sustentável. 
Tabosa, et. al (2016) aplicam a metodologia de Bohn (1998) para os Estados brasileiros, utilizando séries fiscais de 2000 a 2007. Expandem o modelo para permitir que aqueles estados cuja relação dívida/PIB é mais alta que os demais possuam uma reação diferente. Os resultados obtidos apontam que a relação dívida/PIB não é sustentável, posto que a geração de superávit primário não é suficiente face um aumento da dívida. Os autores estão em consonância com Luporini (2015), de que o crescimento econômico e as receitas extraordinárias são os principais fatores que oxigenam o orçamento dos estados.

Como evidenciado nesta revisão de literatura, a metodologia de Bohn (1998) é aquela mais utilizada para testar a hipótese de sustentabilidade da trajetória da dívida de um país ou estado. Utilizou-se desta metodologia para verificar a sustentabilidade da dívida americana, da África do Sul, de países europeus tanto individualmente quanto a partir da metodologia de dados em painel. Para dados nacionais, a tendência encontrada na literatura é a de que, após a Lei de Responsabilidade Fiscal, especialmente após 2003, a função de reação fiscal ficou mais responsiva até o período de pós crise, em 2009, a partir do qual houve piora nesta resposta. Para os Estados Brasileiros, o teste de sustentabilidade seguindo Bohn (1998) vai até 2007, não captando, portanto, este efeito pós crise, e os testes são realizados apenas sobre a dívida líquida dos Estados.

Este trabalho, portanto, visa "preencher" este vácuo, a partir do momento em que aplica a metodologia de Bohn $(1998,2008)$ a uma base de dados mais extensa, 2001 a 2015, incluindo assim o período pós crise, utilizando tanto a dívida consolidada líquida quanto a dívida consolidada bruta dos Estados Brasileiros. A partir do Anexo de Metas Fiscais, presente na Lei de Diretrizes Orçamentárias de cada estado, é possível estender a amostra até 2020, o que enriquece a discussão por trazer parâmetros de natureza fiscal que os estados estabelecem como metas após aprovada a renegociação de suas dívidas.

O trabalho, também, visa identificar se os mecanismos institucionais, como a Lei de Responsabilidade Fiscal, são capazes de controlar o comportamento de endividamento excessivo por parte dos estados. Isto é, verificar se os estados que estão sendo punidos pela Lei de Responsabilidade Fiscal são aqueles cuja trajetória da dívida é não sustentável, enquanto aqueles que não estão sujeitos a punições são aqueles cuja trajetória da dívida é sustentável. Esta análise também será realizada 
em quatro recortes temporais: 2001 a 2015, 2008 a 2015, 2001 a 2020, e 2008 a 2020, de forma a identificar o efeito do relaxamento das restrições às operações financeiras estaduais feita pela União após a crise de 2008. 


\section{METODOLOGIA}

Propõe-se utilizar o modelo desenvolvido em Bohn para estimar a função de reação fiscal dos estados brasileiros $(1998,2008)$. A ideia de tal modelo é estimar a resposta do superávit primário dado um aumento na relação dívida sobre o PIB. Se esta resposta for positiva, isto é, se para um aumento da relação dívida/PIB, há aumento na geração de superávit primário, então há um componente estabilizador da dívida, indicando que a relação dívida/PIB tem reversão à média. Isto implica que há sustentabilidade da dívida.

No entanto, antes de desenvolver a metodologia do autor, será realizada uma revisão conceitual dos parâmetros de interesse, resultado primário e dívida consolidada bruta e líquida.

Define-se resultado primário como a diferença entre receitas e despesas do governo, não se incluindo as despesas e receitas financeiras, como os juros. A intuição do conceito é que ele representa o esforço do ente, em um intervalo de tempo, de economizar para cumprir seus compromissos financeiros.

A dívida consolidada bruta, à luz da Lei de Responsabilidade Fiscal (LRF), corresponde ao montante total, apurado sem duplicidade, das obrigações financeiras do ente da Federação, com prazo de amortização superior a doze meses, decorrentes de leis, contratos, convênios, tratados, e da realização de operações de crédito. Caso a operação de crédito tenha prazo inferior a 12 meses, mas tenha constado no orçamento, também será incluída na dívida consolidada. Por fim, também são considerados os precatórios judiciais emitidos a partir de 5 de maio de 2000 e não pagos durante a execução do orçamento em que houverem sido incluídos.

Para se obter a dívida consolidada líquida, exclui-se do conceito anterior as disponibilidades de caixa do ente, bem como aplicações financeiras e demais haveres financeiros, inclusive empréstimos e financiamentos concedidos. É o conceito mais utilizado na literatura quando da análise da sustentabilidade da dívida.

Finda a revisão de conceitos a serem utilizados, é possível partir para a apresentação do modelo. O ponto de partida da metodologia de Bohn (2008) é a da 
função que expressa como o déficit nominal de um país, que era o caso de interesse de seu trabalho, evolui ao longo do tempo:

$$
\begin{gathered}
D E F_{t}=G_{t}-T_{t}+i_{t} \cdot D_{t-1}(1) \\
D_{t}=D_{t-1}+D E F_{t}(2)
\end{gathered}
$$

Onde $D E F_{t}, G_{t}, T_{t}, i_{t} D_{t}$ são, respectivamente, déficit nominal, gastos do governo, arrecadação do governo, taxa nominal de juros e estoque de dívida nominal para o período t.

A equação (1) expressa que o déficit nominal total em um instante do tempo é a soma dos gastos do governo, incluindo os juros pagos sobre a dívida, menos o total arrecadado. O estoque da dívida, então, é aquele do período anterior acrescido do déficit observado.

Note que a expressão $G_{t}-T_{t}$ em (1) representa o superávit (ou déficit) primário $\left(D E F_{t}^{p}\right)$. Isto é, apresenta o resultado das contas públicas excluindo os gastos com juros. Reescrevendo (1) com esta definição e substituindo em (2), temos:

$$
D_{t}=D E F_{t}^{p}+\left(1+i_{t}\right) \cdot D_{t-1}
$$

Para trabalhar com a noção de dívida em relação ao PIB, é feita a seguinte transformação em (3):

$$
\frac{D_{t}}{Y_{t}}=\frac{D E F_{t}^{p}}{Y_{t}}+\frac{\left(1+i_{t}\right)}{\left(1+\gamma_{t}\right)} \cdot \frac{D_{t-1}}{Y_{t-1}}(4)
$$

Em que $Y_{t}$ é o PIB nominal e $\gamma_{t}$ é a taxa de crescimento nominal do PIB. Podemos reescrever (4) definindo: $s_{t}=-\frac{D E F_{t}^{p}}{Y_{t}} ; r_{t}=\frac{\left(1+i_{t}\right)}{\left(1+\gamma_{t}\right)} \approx i_{t}-\gamma_{t} ; d_{t}=\frac{D t}{Y t}$. Logo, tem-se:

$$
d_{t}=\left(1+r_{t}\right) \cdot d_{t-1}-s_{t}(5)
$$

Temos então uma relação para um dado momento no tempo. Para analisar a esta relação ao longo do tempo, realizam-se substituições sucessivas no termo $d_{t-1}$, obtendo:

$$
\left.d_{t+n}=\left(\prod_{k=0}^{n}\left(1+r_{t+k}\right)\right) \cdot d_{t-1}\right)-\sum_{j=0}^{n}\left(\prod_{k=j+1}^{n}\left(1+r_{t+k}\right)\right) \cdot s_{t+j}(6)
$$


A intuição de (6) é a de que, para se obter o estoque da dívida em relação ao PIB no período $t+n$, basta multiplicar o estoque da dívida no período inicial pelo fator $\left(1+r_{t}\right)$ em cada instante do tempo, chegando assim no valor acumulado da dívida para o período. Subtrai-se deste valor a soma de todos os superávits primários de $\mathrm{t}$ até $\mathrm{n}$, ponderados também pelo fator $\left(1+r_{t}\right)$ a cada instante do tempo.

Admitindo que $r_{t+k}=r_{t+l}=r, l \neq k$, aplica-se a esperança condicional em (5):

$$
E_{t}\left[d_{t+n}\right]=(1+r)^{n} \cdot d_{t}^{*}-\sum_{j=0}^{n}(1+r)^{n-j} \cdot E_{t}\left[s_{t+j}\right](7)
$$

Onde $d_{t}^{*}=\left(1+r_{t}\right) \cdot d_{t-1}$

Dividindo (7) por $(1+r)^{n}$ e rearranjando, tem-se:

$$
d_{t}^{*}=\sum_{j=0}^{n} \frac{1}{(1+r)^{j}} E_{t}\left[s_{t+j}\right]+\frac{1}{(1+r)^{n}} E_{t}\left[d_{t+n}\right](8)
$$

Note que a medida que $\mathrm{n}$ aumenta, o termo $\frac{1}{(1+r)^{n}} E_{t}\left[d_{t+n}\right]$ se aproxima de zero. Vale-se da hipótese de que a soma descontada converge. Assim, tem-se:

$$
d_{t}^{*}=\sum_{j=0}^{n} \frac{1}{(1+r)^{j}} E_{t}\left[s_{t+j}\right]+\lim _{n \rightarrow \infty} \frac{1}{(1+r)^{n}} E_{t}\left[d_{t+n}\right](9)
$$

Em que é possível separar em dois termos:

$$
\begin{gathered}
d_{t}^{*}=\sum_{j=0}^{n} \frac{1}{(1+r)^{j}} E_{t}\left[s_{t+j}\right](10) \\
\lim _{n \rightarrow \infty} \frac{1}{(1+r)^{n}} E_{t}\left[d_{t+n}\right]=0
\end{gathered}
$$

A equação (10) é a Restrição Orçamentária Intertemporal do Governo (ROIG). Note que ela reflete a definição de sustentabilidade da política fiscal - o valor esperado dos futuros superávits primários deve ser igual à dívida/PIB inicial.

A equação (11), por sua vez, é a condição Não-Ponzi. A ideia é que o governo eventualmente paga sua dívida, não podendo endividar-se permanentemente.

Conforme discutido na revisão de literatura, Flavin e Hamilton (1986) estabeleceram que, para ser válida a ROIG, era necessário que a série da dívida não possuísse raiz unitária, o que tornava válida a equação (11) e, indiretamente, a equação (9). Trehan e Walsh (1988) e Hakkio e Rush (1991), por sua vez, assumiram 
que a ROIG era válida se as receitas e despesas fossem cointegradas de forma que a equação (11) fosse válida e, também indiretamente, a equação (10).

Para Bohn (2007), os argumentos anteriores não são necessários ou suficientes para garantir a validade da ROIG: esta pode ser mantida até mesmo em casos em que tais argumentos são violados. Estabelece, então, uma forma de tentar captar o comportamento do policy-maker, a partir da função de reação fiscal, que representaria a estimativa da resposta na geração de superávits primários dada um aumento na relação dívida/PIB.

A função a ser estimada, como proposta em Bohn (2008), é expressa pela equação (12):

$$
s_{t}=\rho \cdot d_{t}^{*}+\beta_{0}+\beta_{g} \cdot \tilde{g}_{t}+\beta_{y} \cdot \tilde{y_{t}}+\varepsilon_{t}
$$

Em que $\tilde{g}_{t}$ e $\widetilde{y_{t}}$ são gastos temporários, de caráter militar, e produto temporário (desvio entre produto potencial e realizado), que será denominado YVAR, $\rho, \beta_{0}, \beta_{g}$ e $\beta_{y}$ são coeficientes e $\varepsilon_{t}$ é o termo de erro de média 0.

No modelo original de Bohn (1998), incluía-se os gastos militares como variável independente na função de reação fiscal, como gastos temporários. Para o caso dos Estados Brasileiros, em que tais gastos militares não se aplicam, estimamos o modelo em sua forma reduzida:

$$
s_{i t}=\rho_{i} \cdot d_{i t}^{*}+\beta_{i 0}+\beta_{i y} \cdot \widetilde{y_{l t}}+\varepsilon_{i t}
$$

Espera-se que $\rho>0$, que indica que há uma resposta positiva por parte do estado na geração de superávit primário quando há aumento na relação dívida/PIB. Assim, (10) e (11) são satisfeitas. Caso $\rho \leq 0$, então um aumento na relação dívida/PIB não gera contrapartida no superávit primário. Então (10) e (11) não são satisfeitas e a dívida não é sustentável.

Serão estimadas as funções de reação fiscal para os 26 estados brasileiros e o Distrito Federal, considerando os anos de 2001 a 2015.

Seguindo o procedimento de Pedroni (2004), a estimação da função de reação fiscal para os estados brasileiros será realizada pelo método de mínimos quadrados dinâmicos (DOLS). O método envolve acrescentar à equação de cointegração valores para trás e para frente de $\Delta X_{t}$, onde $X_{t}$ é a matriz das variáveis independente. Assim, 
o termo de erro da equação de cointegração é ortogonal aos termos de erro de períodos anteriores, resolvendo o problema da simultaneidade. Segundo Saikkonen (1992) e Stock e Watson (1993), reescrevemos a função de reação fiscal:

$$
s_{i t}=\varphi_{i o}+\varphi_{1} \cdot d_{i t-1}^{*}+\gamma_{2} \cdot \widetilde{y_{i t}}+\sum_{j=-q}^{r} \Delta X^{\prime}{ }_{i t+j} \delta_{j}+\vartheta_{1 t}
$$

Novamente, caso $\varphi_{i}>0$, então segundo a metodologia de Bohn o estado será sustentável. Caso contrário, o estado será dito não sustentável. A metodologia permite realizar a estimação considerando os efeitos conjuntos de todos os estados, agrupando-os antes de realizar a regressão, ou realizar a regressão individual em cada cross section e obter a média das cross section como o coeficiente final. A primeira abordagem é mais rica no sentido que será possível captar efeitos comuns a todos os estados ou a grupos de estados. No entanto, o custo de oportunidade desta abordagem é o de não ser possível obter os coeficientes individuais de cada estado.

Como serão contempladas as dívidas consolidadas líquidas e brutas simultaneamente, será estabelecido um critério caso o coeficiente de apenas uma delas seja positivo e estatisticamente distinto de zero. Caso o coeficiente não significativo seja o da dívida consolidada líquida, assumir-se-á que o coeficiente relacionado a dívida consolidada bruta é mais forte e, sendo positivo, dir-se-á que o estado ou grupo de estados segue uma trajetória sustentável de dívida. No entanto, caso o coeficiente não significativo seja o da dívida consolidada bruta, mesmo com o coeficiente da dívida consolidada líquida sendo significativo, será dito que o estado ou grupo de estados não segue uma trajetória sustentável da dívida.

O critério acima será utilizado devido ao fato de que, conforme discutido, a dívida consolidada líquida é igual à dívida consolidada bruta descontadas as disponibilidades de caixa do ente, aplicações financeiras e demais haveres financeiros. Logo, se apenas o endividamento líquido de um estado for considerado sustentável, então o processo gerador da dívida, representado pela dívida bruta, não é sustentável, e as disponibilidades de caixa temporariamente atenuam este efeito.

Uma forma de enriquecer a análise é, adicionalmente ao painel completo com todos os estados, aplicar a metodologia a recortes de painéis, como em Mendoza e Ostry (2008), que aplicou a metodologia de Bohn a um painel de países, e subdividiu sua amostra em países desenvolvidos e emergentes, separando-as também em 
grupos de países mais ou menos endividados, chegando a um resultado de que os países desenvolvidos eram menos rigorosos em sua política fiscal do que os emergentes, e o coeficiente de reação fiscal era maior em países menos endividados.

Desta forma, serão estimados 5 modelos, seguindo a descrição abaixo:

1. Painel completo com todos os estados e Distrito Federal.

2. Separação por regiões (Norte, Nordeste, Centro Oeste, Sudeste, Sul)

3. Separação por estados mais endividados e menos endividados, seguindo o critério endógeno de Mendoza e Ostry (2008).

4. Separação seguindo os critérios da Lei de Responsabilidade Fiscal quanto o limite dos gastos com pessoal (limite máximo, prudencial, alerta e estados que não ultrapassaram nenhum limite).

5. Separação seguindo a resolução no.40 do Senado Federal quanto a relação dívida consolidada líquida sobre receita corrente líquida (estados cuja relação DCL/RCL for maior que 2, demais estados).

Para cada um destes modelos a estimação se dará em quatro intervalos de tempo. O primeiro é o período que compreende a amostra completa, de 2001 a 2015. O segundo compreenderá o período de 2008 a 2015, de forma a verificar a hipótese de que os controles sobre o endividamento estatal foram relaxados durante o período pós-crise. A escolha pelo ano de 2008 baseia-se no fato estilizado de ser o ano de início da manifestação dos efeitos da crise econômica de 2008, o que, como visto no gráfico 3, gerou um pico na trajetória das dívidas estaduais. O terceiro período será o de 2001 a 2020. Esta expansão da amostra é possível pois todo estado, por lei, deve anualmente publicar a sua Lei de Diretrizes Orçamentárias. Como anexo à estas leis, os estados devem estabelecer metas fiscais para 2020 para dívida consolidada, dívida consolidada líquida e resultado primário. A incorporação destas metas na base de dados permite analisar o problema de forma mais contemporânea, já que indicam os cenários a serem enfrentados pelos estados no futuro. Por fim, o último período considerado é o de 2008-2020, novamente para testar a hipótese de que os controles da LRF foram relaxados após a crise de 2008.

Todas as variáveis de interesse estão em nível. Assim, não se pode entender o coeficiente de reação fiscal (CRF) como uma elasticidade. A interpretação mais intuitiva do CRF seria a de que este fornece o resultado primário esperado, dado que 
houve uma variação na relação dívida sobre PIB. No entanto, é factível a comparação dentro do mesmo modelo em distintos instantes do tempo, já que o grupo é o mesmo ao longo do tempo.

Como condição para a robustez das estimações, é preciso verificar se as regressões da função de reação fiscal não são espúrias. Isto será feito a partir do teste de cointegração para dados em painel proposto por Pedroni (2004). Logo, é preciso verificar se as séries possuem a mesma ordem de integração. O teste de raiz unitária a ser aplicado é o de Im, Pesaran e Shin (2003). Tanto o teste de cointegração quanto o de raiz unitária serão desenvolvidos na seção posterior, junto com os resultados obtidos.

As variáveis de interesse são, então, o superávit primário, dívida líquida (principal indicador de solvência), dívida bruta (conceito para indicar sustentabilidade da dívida), sendo o desvio do produto em relação ao valor de equilíbrio, obtido pela aplicação do filtro-HP às séries dos PIBs estaduais, a variável de controle.

Os dados sobre PIB estadual estão disponíveis na série "Contas Regionais do Brasil”, do IBGE, até 2015. Os dados de superávit primário, dívida consolidada líquida e dívida consolidada bruta, até 2017, foram obtidos a partir dos relatórios de gestão fiscal e relatórios resumidos de execução orçamentária, obtidos nas secretarias da fazenda de cada estado4. Para ampliar a amostra até 2020 , utilizou-se as previsões para o PIB estadual, resultado primário, dívida consolidada bruta e líquida presentes no anexo de metas fiscais da Lei de Diretrizes Orçamentárias de 2018 de cada estado, disponíveis nos portais de transparência destes entes. Para obter o PIB estadual entre 2016 e 2017, utilizou-se como referência o crescimento da economia brasileira no período.

Esta extensão da amostra, no entanto, exige cuidados. Ainda que, por lei, os estados devam apresentar a metodologia sob a qual desenvolveram suas metas fiscais, justificando as diferenças entre o previsto e o materializado, há sempre a dúvida de que estas metas estariam superestimando o valor real. No entanto, ainda que este viés "otimista" das estimativas exista, ele acaba por trazer um adicional de robustez no caso em que a trajetória da dívida de determinado estado seja dita não

\footnotetext{
${ }^{4} \mathrm{~A}$ apresentação gráfica das série do PIB estadual, do resultado primário, bem como da dívida consolidada líquida e bruta como proporção do PIB (2001-2015) está disponível no anexo A.
} 
sustentável. Isto porque se metas de resultado primário "infladas" são incapazes de retomar a trajetória da dívida à sua média, então o realizado, que nessa hipótese será menor, tão pouco será capaz de garantir uma política fiscal sustentável. 


\section{RESULTADOS}

A função de reação fiscal que será estimada para os estados, desenvolvida na seção anterior, se dá pela expressão seguinte:

$$
s_{i t}=\varphi_{i o}+\varphi_{i} \cdot d_{i t-1}^{*}+\gamma_{i} \cdot \widetilde{y_{i t}}+\sum_{j=-q}^{r} \Delta X^{\prime}{ }_{i t+j} \delta_{j}+\vartheta_{i t}
$$

Os modelos serão estimados considerando tanto a dívida consolidada bruta quanto a dívida consolidada líquida. O procedimento inicial a ser considerado é o da verificação de se as séries possuem raiz unitária. Caso possuam a mesma ordem de integração, sendo esta maior que zero, prosseguiremos para o teste de cointegração para, enfim, estimarmos a função de reação fiscal

\subsection{RAIZ UNITÁRIA}

Por se tratarem de dados em painel, os testes de raiz unitária diferem dos testes convencionais. A grande vantagem em se utilizar os testes de raiz unitárias para dados em painel é o de se aumentar o poder do teste. O teste utilizado será o de Im, Pesaran e Shin (2003), que permite que o coeficiente de teste $\rho_{i}$ seja diferente para cada estado no painel, conforme a equação seguinte:

$$
y_{i t}=\rho_{i} y_{i t-1}+X_{i t} \delta_{i}+\epsilon_{i t}
$$

Em que $\mathrm{i}=1,2, \ldots, 27 ; \mathrm{t}=2001,2002, \ldots, 2015 . X_{i t}$ seriam as variáveis exógenas ao modelo, como efeitos fixos ou tendências individuais, e o $\rho_{i}$ é o coeficiente autoregressivo, distinto para cada estado, e o termo de erro $\epsilon_{i t}$ é tido como mutuamente independente. Caso $\left|\rho_{i}\right|<1$, então $y_{i}$ é fracamente estacionária. Caso contrário, então a série possui raiz unitária.

A intuição do teste de Im, Pesaran e Shin é o de realizar o teste de DickeyFuller aumentado em cada cross-section, obtendo a média das estatísticas, $\bar{t}_{N T}$. Os autores demonstram que a estatística padronizada possui distribuição normal padrão.

Aplicando o teste Im, Pesaran e Shin, com auxílio computacional do software Eviews, para as séries de resultado primário/PIB, dívida consolidada líquida e 
bruta/PIB, e produto temporário, de 2001 a 2015, obtém-se os resultados expressos na tabela que segue:

Tabela 4 - Teste de Im, Pesaran e Shin (2003)

Hipótese nula: Há raiz unitária.

\begin{tabular}{|c|c|c|c|c|c|c|}
\hline Variável & \multicolumn{2}{|l|}{ Nível } & \multicolumn{2}{|c|}{ Primeira Dif. } & \multicolumn{2}{|c|}{ Segunda Dif. } \\
\hline & $\mathrm{C}$ & $\mathrm{C}+$ Trend & $\mathrm{C}$ & $\mathrm{C}+$ Trend & $\mathrm{C}$ & $\mathrm{C}+$ Trend \\
\hline$\widetilde{Y t}$ & $\begin{array}{l}-1,20390 \\
(0,1143)\end{array}$ & $\begin{array}{l}2,05405 \\
(0,9800)\end{array}$ & $\begin{array}{l}-4,43 * * * \\
(0,0000)\end{array}$ & $\begin{array}{l}-3,79 * * * \\
(0,0000)\end{array}$ & $\begin{array}{l}-11,4 * * * \\
(0,0000)\end{array}$ & $\begin{array}{l}-7,13 * * * \\
(0,0000)\end{array}$ \\
\hline$S_{i t}$ & $\begin{array}{l}-0.95770 \\
(0,1691)\end{array}$ & $\begin{array}{l}-3,91 * * * \\
(0,0000)\end{array}$ & $\begin{array}{l}-11.1 * * * \\
(0,0000)\end{array}$ & $\begin{array}{l}-7.88 * * * \\
(0,0000)\end{array}$ & $\begin{array}{l}-14.75 * * * \\
(0.0000)\end{array}$ & $\begin{array}{l}-10.34 * * * \\
(0.0000)\end{array}$ \\
\hline DC/PIB & $\begin{array}{l}-4.137 * * * \\
(0,0000)\end{array}$ & $\begin{array}{l}-0.24280 \\
(0,4041)\end{array}$ & $\begin{array}{l}-10.1 * * * \\
(0,0000)\end{array}$ & $\begin{array}{l}-12.9 * * * \\
(0,0000)\end{array}$ & $\begin{array}{l}-22.6 * * * \\
(0,0000)\end{array}$ & $\begin{array}{l}-16.7 * * * \\
(0,0000)\end{array}$ \\
\hline DCL/PIB & $\begin{array}{l}-7.068 * * * \\
(0,0000)\end{array}$ & $\begin{array}{l}7.74967 \\
(1,0000)\end{array}$ & $\begin{array}{l}-0.76494 \\
(0,2222)\end{array}$ & $\begin{array}{l}-4,55 * * * \\
(0,0000)\end{array}$ & $\begin{array}{l}-11.70 * * * \\
(0,0000)\end{array}$ & $\begin{array}{l}-8.23 * * * \\
(0,0000)\end{array}$ \\
\hline
\end{tabular}

Fonte: Elaboração própria. Valores com $\left.{ }^{* * *}\right)$ indicam que a hipótese nula é rejeitada a um nível de $1 \%$ de significância.

As variáveis foram analisadas em nível, e em primeira e segunda diferenças. $\mathrm{Na}$ primeira coluna, acrescenta-se apenas a constante ao modelo, enquanto na segunda coluna, a constante e tendência. Em parênteses, está representado o p-valor do teste. Conclui-se, então, que as variáveis possuem raiz unitária, sendo integradas de ordem 1.

\subsection{COINTEGRAÇÃO}

Como as séries são todas integradas de ordem 1, então o próximo passo é conferir se elas cointegram, isto é, se a combinação linear destas variáveis é estacionária.

No caso tradicional, em que há apenas uma cross-section a se analisar, há dois principais métodos: o de Engle-Granger (1987) e Johansen (1991). No primeiro, há dois passos. Estima-se a equação de interesse com as variáveis em nível, obtendo o resíduo da regressão. Depois, aplica-se o teste de Dickey-Fuller aumentado sob estes 
resíduos. Caso os resíduos não possuam raiz unitária, então as séries cointegram. Já o procedimento de Johansen implica na estimação de um VAR com as variáveis de interesse, que pode ser expresso da forma matricial:

$$
\Delta X_{t}=\pi X_{t}+\sum_{i=1}^{p-1} r_{i} \Delta X_{t-i}+\epsilon_{t}, r_{i}=-\sum_{j=i+1}^{p} \pi_{j}, \pi=\pi_{1}+\cdots+\pi_{p}-I
$$

Se o posto da matriz $\pi$ for zero, então não há cointegração. Caso o posto seja completo, então há alguma variável que não é de fato I(1). Por fim, caso o posto seja incompleto, mas maior que zero, então as variáveis cointegram. Como condição para o procedimento de Johansen, é necessário estabelecer o modelo de cointegração a ser testado, dentre os seguintes:

1. Sem tendência e constante no nível e no vetor de cointegração

2. Constante no vetor de cointegração

3. Constante dentro e fora do vetor de cointegração

4. Constante dentro e fora do vetor de cointegração, tendência linear no vetor de cointegração

5. Constante e tendência linear dentro e fora do vetor de cointegração

Os testes de cointegração para dados em painel são baseados nestes vistos acima. O teste de Pedroni $(1999,2004)$ baseia-se em Engle Granger, expandindo este modelo para dados em painel. Partindo da seguinte equação:

$$
y_{i t}=\alpha_{i}+\delta_{i} t+\beta_{1 i} x 1_{i t}+\cdots+\beta_{M i} X_{M i, t}+\varepsilon_{i, t}
$$

Em que $t=1, \ldots, T ; i=1, \ldots, N ; m=1, \ldots, M$. y e x são variáveis $\mathrm{I}(1)$. Os parâmetros $\alpha_{i}$ e $\delta_{i}$ representam os efeitos da constante individual e da tendência, que podem ser iguais a 0 .

Aplica-se, para cada cross-section, o teste de Dickey-Fuller aumentado, a partir da seguinte expressão:

$$
\varepsilon_{i t}=\rho_{i} \varepsilon_{i t-1}+\sum_{j=1}^{p_{i}} \psi_{i j} \Delta \varepsilon_{i t-j}+v_{i t}
$$

A hipótese nula do teste é a de que $\rho_{i}=1$, isto é, as séries não cointegram. A hipótese alternativa é $\rho_{i}<1$, para todo i. São geradas 11 estatísticas, referentes aos 
testes de raiz unitária utilizados sob o resíduo. Caso a maioria das estatísticas indique que os resíduos não possuem raiz unitária, então as variáveis são cointegradas.

Serão realizados os testes de Pedroni sob os 2 modelos distintos. O modelo $\mathrm{A}$ analisa se as seguintes variáveis cointegram: resultado primário/ $\mathrm{PIB}$, produto temporário e dívida consolidada líquida. O modelo $\mathrm{B}$ substitui a dívida consolidada líquida pela dívida consolidada bruta. Os resultados para o teste de Pedroni constam nas tabelas abaixo:

Tabela 5 - Teste de cointegração para o modelo A

Hipótese nula: não há cointegração.

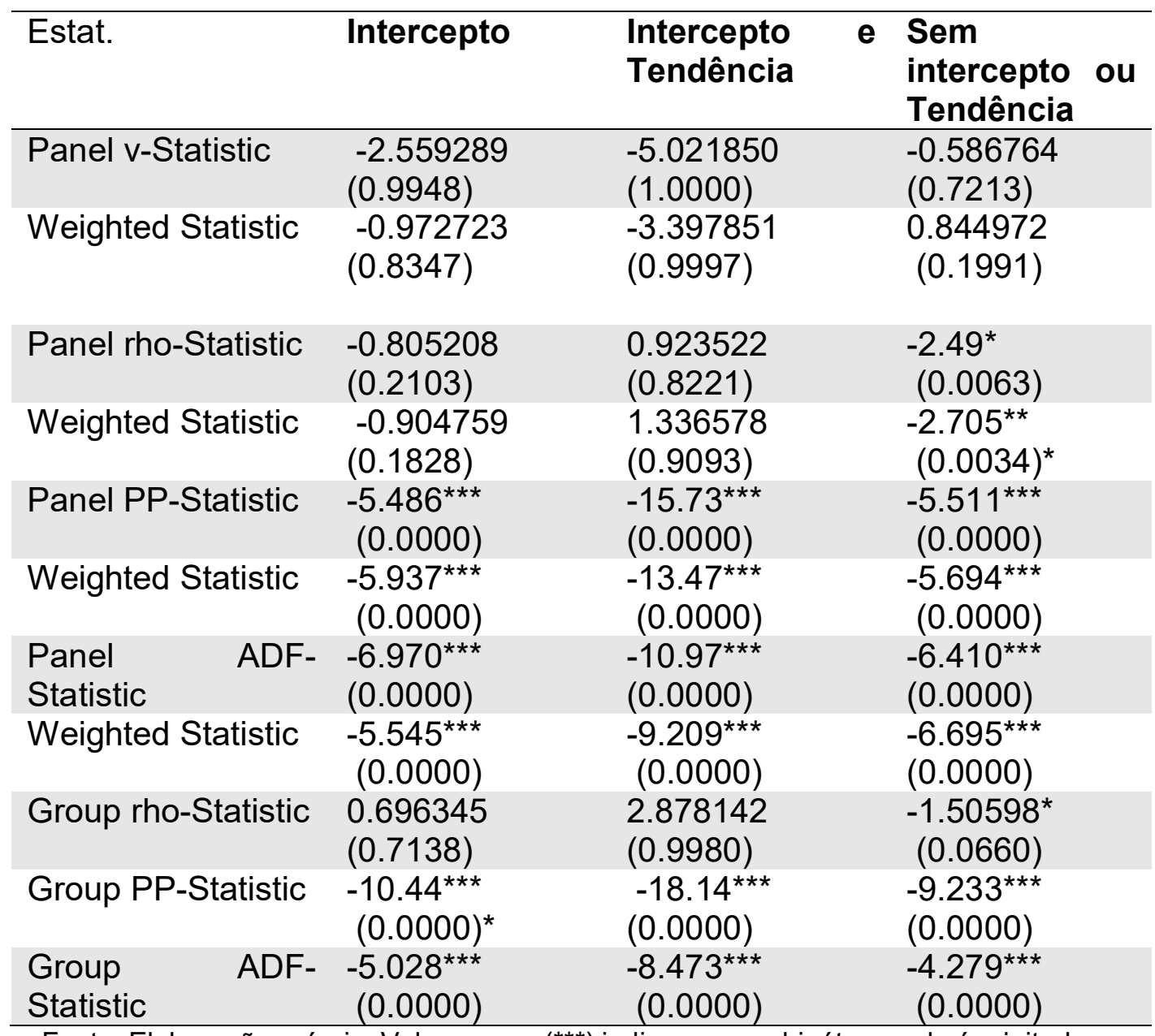

Fonte: Elaboração própria. Valores com $\left.{ }^{* * *}\right)$ indicam que a hipótese nula é rejeitada a um nível de $1 \%$ de significância. Valores com $\left({ }^{* *}\right)$ e $\left(^{*}\right)$ indicam, respectivamente, rejeição da hipótese nula a um nível de $5 \%$ e $10 \%$.

A hipótese nula é a de que não há cointegração. Logo, a um nível de $5 \%$, rejeitase a hipótese nula se o p-valor for menor do que $5 \%$. No modelo apenas com intercepto, 6 das 11 estatísticas possuem p-valor menor que 5\%, sendo assinaladas com o asterisco. No modelo com intercepto e tendência, há também 6 estatísticas que 
indicam que há cointegração. No modelo sem intercepto ou tendência, 8 estatísticas indicam que há cointegração. Assim, com base no teste de Pedroni, as 3 variáveis (resultado primário/PIB, dívida consolidada líquida e produto temporário) são cointegradas.

Tabela 6 - Teste de cointegração para o modelo B

Hipótese nula: não há cointegração.

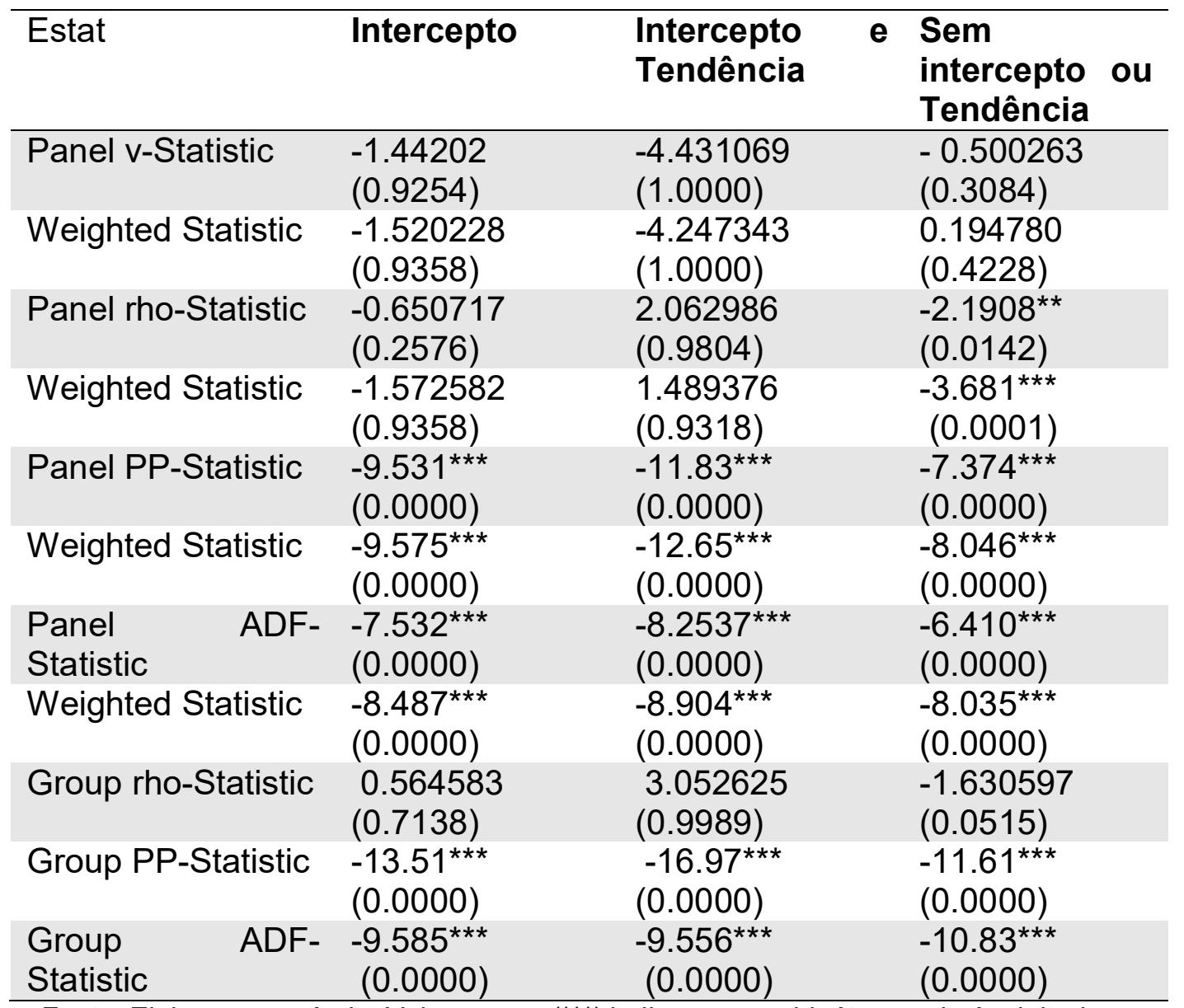

Fonte: Elaboração própria. Valores com $\left.{ }^{* * *}\right)$ indicam que a hipótese nula é rejeitada a um nível de $1 \%$ de significância. Valores com $\left({ }^{* *}\right)$ e $\left(^{*}\right)$ indicam, respectivamente, rejeição da hipótese nula a um nível de $5 \%$ e $10 \%$.

A hipótese nula do teste de Pedroni é que não há cointegração, logo, a um nível de $5 \%$ de significância, para o caso em que incluímos apenas o intercepto, 6 estatísticas indicam que há cointegração. Para o caso em que incluímos intercepto e tendência, 6 estatísticas indicam que há cointegração. Por fim, quando não há intercepto ou tendência, 8 estatísticas indicam que há cointegração. Conclui-se, a partir do teste, que as séries do resultado primário/PIB, dívida consolidada bruta/PIB e produto temporário são cointegradas. 
Maddala e Wu (1999) derivam um teste, denominado de teste de Fisher, baseando-se no procedimento de Johansen (1991). A ideia é combinar os resultados individuais de cada cross-section do procedimento de Johansen, obtendo assim o teste para todo o painel.

Seja $\pi_{i} \circ \mathrm{p}$-valor do teste individual de cointegração para a cross-section i, então sob a hipótese nula:

$$
-2 \sum_{i=1}^{N} \log \left(\pi_{i}\right) \rightarrow \chi_{2 N}^{2}
$$

A aplicação do teste de Fisher ao caso dos estados brasileiros é inadequada, pois durante o processo de estimação do vetor de cointegração, deve-se especificar o modelo de testes, dentro de 5 possíveis explicitados anteriormente. No entanto, não necessariamente o modelo de um estado será igual ao de outro estado. Durante a elaboração deste trabalho, percebeu-se não ser este o caso: para o estado da Bahia, o modelo de cointegração era o 4: constante dentro e fora do vetor de cointegração, tendência linear no vetor de cointegração. No entanto, para o caso do Rio de Janeiro, o modelo indicado era o 2. O teste de cointegração para a Bahia utilizando o modelo 2, e o do Rio de Janeiro utilizando o modelo 4 indicaram que não haveria vetor de cointegração. Logo, por não ser possível agregar cross-sections com modelos distintos, não poderá ser utilizado o teste de Fisher para verificar a cointegração.

Assim, com base no teste de Pedroni, concluímos que tanto o modelo 1 , considerando a dívida consolidada líquida, quanto o modelo 2 , em que se inclui a dívida consolidada bruta, são cointegrados. O próximo passo é partir para a estimação da função de reação fiscal para ambos os modelos.

\subsection{ESTIMAÇÃO DA FUNÇÃO DE REAÇÃO FISCAL}

Seguindo o procedimento de Pedroni (2004), parte-se para a estimação da função de reação fiscal utilizando o método de mínimos quadrados dinâmicos (DOLS). Conforme explicitado na seção anterior, serão estimados cinco modelos, com quatro cortes temporais em cada um destes modelos. Os dados desta seção serão expostos 
de maneira sucinta, com foco no coeficiente de interesse da função de reação fiscal, $\varphi$. O anexo II deste trabalho conterá as saídas completas da estimação.

Como forma de interpretação de coeficientes, segue-se o modelo de Bohn. Caso o coeficiente de dado grupo seja positivo e estatisticamente distinto de zero, a um nível de $5 \%$ de significância, será dito que este grupo, como um todo, segue uma política fiscal sustentável. Como serão contempladas as dívidas consolidadas líquidas e brutas simultaneamente, será estabelecido o critério descrito anteriormente, caso o coeficiente de apenas uma delas seja positivo e estatisticamente distinto de zero, de considerar que o coeficiente de reação fiscal da dívida bruta como o mais robusto.

Assim, o primeiro modelo é aquele que considera o efeito de todos os 27 estados. Apresenta o panorama geral dos estados. No entanto, dado que tais entes são por definição heterogêneos, os outros modelos servem por incrementar a análise inicial. Os resultados da estimação do primeiro modelo, considerando os recortes temporais, constam na tabela seguinte, em que os termos em parêntese são os desvios padrão dos coeficientes.

Tabela 7 - Modelo 1: Painel Completo

\begin{tabular}{lll}
\hline Período & Dívida Líquida & Dívida Bruta \\
\hline $2001-2015$ & $0.056002^{* * *}$ & $0.052232^{\star * *}$ \\
& $(0.012127)$ & $(0.015466)$ \\
$2008-2015$ & 0.014801 & 0.015546 \\
& $(0.014710)$ & $(0.012103)$ \\
$2001-2020$ & $0.027025^{* *}$ & $0.023112^{* *}$ \\
& $(0.010515)$ & $(0.010493)$ \\
$2008-2020$ & 0.012567 & 0.008061 \\
& $(0.008424)$ & $(0.006913)$
\end{tabular}

Fonte: Elaboração própria. Valores com $\left.{ }^{* * *}\right)$ indicam que a hipótese nula é rejeitada a um nível de $1 \%$ de significância. Valores com $\left({ }^{* *}\right)$ e $\left(^{*}\right)$ indicam, respectivamente, rejeição da hipótese nula a um nível de $5 \%$ e $10 \%$.

Os resultados indicam que, para o período de 2001 a 2015, os estados conduziram uma política fiscal sustentável. No entanto, esta política fiscal se tornou, de forma geral, menos sustentável ao longo do tempo. Quando considerado o período de 2001 a 2020, o coeficiente de reação fiscal cai pela metade em relação ao período 
2000 a 2015. Naturalmente, os coeficientes associados à dívida bruta tendem a ser menores do que os da dívida líquida, posto que o montante da primeira é sempre maior ou igual ao da segunda.

A tese de que os controles ao processo de endividamento foram relaxados parece ser validada pelos resultados. Tanto para período 2008 a 2015 quanto para período de 2008 a 2020 os estados não seguiram uma política fiscal sustentável, posto que o coeficiente não é estatisticamente distinto de zero.

Os resultados sugerem, assim, que os estados seguiam uma política fiscal sustentável até 2007 , mas este comportamento se deteriorou a partir de 2008, em que não mais seguiram uma trajetória de endividamento sustentável, em um processo que persistirá até 2020 .

No entanto, o resultado agregado não permite identificar as peculiaridades de cada estado. É possível que haja um grupo de estados cujo processo de endividamento é sustentável, e um grupo que não seja.

Para verificar se é este o caso, o conjunto de estados será dividido em subconjuntos nos modelos seguintes a partir de certos critérios. O próximo modelo é aquele que analisa a função de reação fiscal dos estados a partir da região que ocupam. A agregação por regiões é válida pois os estados são relativamente homogêneos dentro daquela região, mas as regiões são entre si heterogêneas, como verificado na tabela 2. Assim, a estimação por regiões pode fornecer indicativos de que os estados são distintos entre si na condução de sua política fiscal.

Os resultados da estimação da função de reação fiscal dos estados, divididos por regiões, constam na tabela abaixo:

Tabela 8 - Modelo 2: Estimação por Regiões

\begin{tabular}{lll}
\hline Período & Dívida Líquida & Dívida Bruta \\
\hline Região Norte & & \\
\hline $2001-2015$ & 0.094713 & $0.096855^{\star *}$ \\
& $(0.057967)$ & $(0.041802)$ \\
$2008-2015$ & -0.024292 & 0.016712 \\
& $(0.055645)$ & $(0.036256)$
\end{tabular}




\begin{tabular}{|c|c|c|}
\hline \multirow[t]{2}{*}{$2001-2020$} & 0.041750 & 0.032803 \\
\hline & $(0.04112)$ & $(0.034009)$ \\
\hline \multirow{2}{*}{$2008-2020$} & 0.010532 & 0.01070736 \\
\hline & $(0.030214)$ & (0.020227) \\
\hline \multicolumn{3}{|c|}{ Região Nordeste } \\
\hline \multirow[t]{2}{*}{ 2001-2015 } & $0.058066^{* \star *}$ & $0.046616^{* * *}$ \\
\hline & $(0.006564)$ & $(0.006711)$ \\
\hline \multirow[t]{2}{*}{ 2008-2015 } & $0.028748^{\star *}$ & 0.015423 \\
\hline & $(0.011059)$ & $(0.009310)$ \\
\hline \multirow[t]{2}{*}{$2001-2020$} & $0.035815^{* * *}$ & $0.027791^{* * *}$ \\
\hline & (0.006108) & $(0.006535)$ \\
\hline \multirow[t]{2}{*}{$2008-2020$} & $0.027920^{* * *}$ & $0.014806^{*}$ \\
\hline & $(0.008604)$ & $(0.007814)$ \\
\hline \multicolumn{3}{|c|}{ Centro Oeste } \\
\hline \multirow[t]{2}{*}{$2001-2015$} & $0.059309^{* \star \star}$ & $0.048999^{* * *}$ \\
\hline & (0.007591) & $(0.006955)$ \\
\hline \multirow[t]{2}{*}{$2008-2015$} & $0.098117^{* * *}$ & 0.041996 \\
\hline & (0.019986) & $(0.022083)$ \\
\hline \multirow[t]{2}{*}{ 2001-2020 } & $0.036489^{* * *}$ & $0.020008^{*}$ \\
\hline & (0.010245) & $(0.011830)$ \\
\hline \multirow[t]{2}{*}{$2008-2020$} & 0.022196 & -0.002055 \\
\hline & $(0.014951)$ & $(0.014171)$ \\
\hline \multicolumn{3}{|l|}{ Sudeste } \\
\hline \multirow[t]{2}{*}{$2001-2015$} & $0.042354^{* * *}$ & $0.037260^{* * *}$ \\
\hline & (0.009623) & $(0.014582)$ \\
\hline \multirow[t]{2}{*}{ 2008-2015 } & $0.013519^{*}$ & $0.004863^{*}$ \\
\hline & (0.012996) & (0.012238) \\
\hline \multirow[t]{2}{*}{$2001-2020$} & $0.006979^{*}$ & $0.009483^{*}$ \\
\hline & (0.009394) & $(0.008836)$ \\
\hline $2008-2020$ & $-0.005118^{*}$ & $-0.004070^{*}$ \\
\hline
\end{tabular}


$(0.009801) \quad(0.008859)$

\begin{tabular}{lll}
\hline Sul & & \\
\hline $2001-2015$ & $0.022947^{* * *}$ & $0.026135^{\star *}$ \\
& $(0.007851)$ & $(0.007255)$ \\
$2008-2015$ & $0.018381^{* *}$ & $0.017289^{* *}$ \\
& $(0.007904)$ & $(0.006848)$ \\
$2001-2020$ & $0.014483^{* * *}$ & $0.008789^{*}$ \\
& $(0.005339)$ & $(0.004892)$ \\
$2008-2020$ & $0.011347^{* *}$ & $0.011446^{* *}$ \\
& $(0.005523)$ & $(0.005383)$
\end{tabular}

Fonte: Elaboração própria. Valores com $\left.{ }^{(* *}\right)$ indicam que a hipótese nula é rejeitada a um nível de $1 \%$ de significância. Valores com $\left({ }^{* *}\right)$ e $\left({ }^{*}\right)$ indicam, respectivamente, rejeição da hipótese nula a um nível de $5 \%$ e $10 \%$.

A estimação do modelo 2 fornece indicativos de que as trajetórias da dívida dos estados são distintas quanto a sua qualidade de serem sustentáveis.

Para o período de 2001 a 2015, todos os estados adotam uma política fiscal sustentável. Importante notar que os estados da região sul e sudeste possuem uma reação inferior ao do painel completo, enquanto as demais regiões possuem um coeficiente de reação maior. No entanto, quando considerados apenas o período póscrise, de 2008 a 2015, são sustentáveis apenas as trajetórias de dívida dos estados da região sul. É importante notar que, no painel completo, todos os estados possuem uma política fiscal insustentável para o período. A estimação do modelo 2 indica que, ainda que no geral, as dívidas dos estados sejam insustentáveis para o período, existem alguns estados que seguiram políticas fiscais suficientemente reativas. No entanto, ainda que a trajetória da dívida dos estados da região Sul tenha permanecido sustentáveis, houve uma piora de $20 \%$ no coeficiente de reação.

Considerando o período de 2001 a 2020, por sua vez, percebe-se um resultado relativamente distinto ao período 2001 a 2015. Agora, apenas a região Nordeste e Sul seriam sustentáveis ${ }^{5}$ em sua política fiscal. Ainda assim, os coeficientes são,

\footnotetext{
${ }^{5}$ O p-valor da estimação do coeficiente de reação fiscal para o período 2000 a 2020, considerando a dívida consolidada líquida foi inferior a $8 \%$. Logo, observando também os coeficientes em todos os demais períodos, utilizou-se pontualmente um critério distinto de considerar que o coeficiente da dívida consolidada líquida seria mais forte do que o da dívida consolidada bruta.
} 
respectivamente, $38 \%$ e $36 \%$ menores, para a dívida consolidada líquida, e $40 \%$ e $66 \%$, também respectivamente, para a dívida consolidada bruta. Quando considerado o período 2008 a 2020, que dá maior ênfase à contemporaneidade do problema, e em que no painel completo há o indicativo de não sustentabilidade para os estados, apenas os estados da região sul aparentam seguir uma política fiscal sustentável, considerando tanto a dívida consolidada bruta quanto a líquida. Ainda assim, o coeficiente de reação é cerca de 50\% menor do que aquele do período de 2001 a 2015. Os estados do Nordeste como um todo, no período, sinalizam que não mais seguiriam uma trajetória sustentável, evidenciando uma piora da condução da política fiscal nos anos mais recentes.

A estimação da função de reação fiscal dividindo os estados por regiões fornece indicativos de que o comportamento dos estados na condução de sua política fiscal foi heterogêneo. Sendo isto verdade, é necessário testar se os mecanismos institucionais, que visam estabelecer limites para os endividamentos, são capazes de gerar equilíbrios separadores, em que os estados que ultrapassem os limites estabelecidos em lei sejam aqueles que não estejam conduzindo a sua política fiscal de maneira sustentável, enquanto aqueles estados que não estejam sujeitos a nenhuma punição sejam aqueles cujo coeficiente de reação fiscal são estatisticamente maiores que zero. Isto é, verificar se não há nenhum estado "irresponsável" em sua política fiscal que não sejam constrangidos pelos limites impostos por mecanismos, como a Lei de Responsabilidade Fiscal ou Resolução no. 40 do Senado Federal e, assim, não estariam sujeitos às punições previstas. Logo, seria uma forma de avaliar se estes mecanismos são capazes de desincentivar comportamentos de endividamento excessivo por parte dos entes federativos, como em um comportamento de risco moral, conforme discutido em capítulos anteriores.

No entanto, antes de testar se os limites estabelecidos pela LRF e pela Resolução no. 40 do Senado Federal geram equilíbrios separadores, será realizada a estimação do modelo 3. Este é baseado em Mendoza e Ostry (2008), que estimam a função de reação fiscal para um painel de países. Eles separam os países a partir de um limite endógeno. Países cuja média da relação dívida/PIB sejam maiores que a média e a mediana do painel são tratados como países cuja dívida é alta. Aos demais, denominam dívida baixa. 
O interesse com a estimação é o de se um limite, ainda que endógeno, ser capaz de separar os estados sustentáveis e os não sustentáveis em sua política fiscal. Caso o equilíbrio separador exista, o modelo então pode servir como parâmetro para a elaboração de medidas que, tornando agora o limite exógeno e bem definido, seja eficaz na medida em que puna os estados que não estejam perseguindo uma trajetória de dívida sustentável.

Um limite exógeno é necessário porque um limite endógeno seria por definição ineficiente. O valor da relação dívida/PIB que separaria os estados em dívida alto e dívida baixo seria estabelecido após os resultados concretos ocorrerem. Logo, isto favoreceria dois cenários para um dado estado.

O primeiro seria imaginar que os outros estados seguirão uma política não sustentável, aumentando seus gastos, com a ideia de que todos assim o fariam, aumentando a relação dívida/PIB de todos os entes federativos. Logo, se aumentar os seus gastos marginalmente, o estado conseguiria obter vantagens políticas pela maior realização de seus projetos, bem como poderia não ser punido posto que todos os outros entes também aumentariam seus gastos. Logo, a imposição de um limite endógeno acabaria por tornar os estados menos sustentáveis em média em suas políticas fiscais, o que seria ineficiente.

O outro cenário é o oposto, em que os estados enxergam que seus vizinhos irão realizar esforços fiscais para reduzir a sua relação dívida/PIB. No entanto, se isto ocorre, então a relação dívida/PIB que gera um equilíbrio separador pode ser ainda menor que aquela do estado que já realizou um significativo esforço fiscal. Logo, ainda que esteja comprometido em ter uma política fiscal sustentável, aquele estado poderá continuar sendo continuamente punido pela existência do limite endógeno. Assim, este último também seria ineficiente.

Isto posto, conclui-se que o limite endógeno, caso exista, deverá ser apenas um indicativo de que a separação dos estados em razão de seguirem trajetórias sustentáveis de sua dívida é factível. Às instituições, às leis e demais mecanismos caberão o papel de realizar um desenho de mecanismos que tornem estes limites exógenos, pré-determinados e iguais a todos os estados.

Assim, utilizando o critério de Mendoza e Ostry (2008) para separar endogenamente os estados em dívida alta e baixa, obtemos dois grupos. No grupo de 
dívida alta estão inseridos os estados do Acre, Alagoas, Goiás, Maranhão, Minas Gerais, Mato Grosso do Sul, Piauí, Rio de Janeiro, Rondônia, Rio Grande do Sul e São Paulo. No grupo de dívida baixa estão o Amapá, Amazonas, Bahia, Ceará, Distrito Federal, Espírito Santo, Mato Grosso, Pará, Paraíba, Pernambuco, Rio Grande do Norte, Roraima, Santa Catarina, Sergipe e Tocantins. O gráfico abaixo apresenta a dispersão da média da relação dívida consolidada líquida/PIB, para o período 2001 a 2015, dos 27 estados:

Gráfico 6 - Relação dívida sobre produto interno bruto

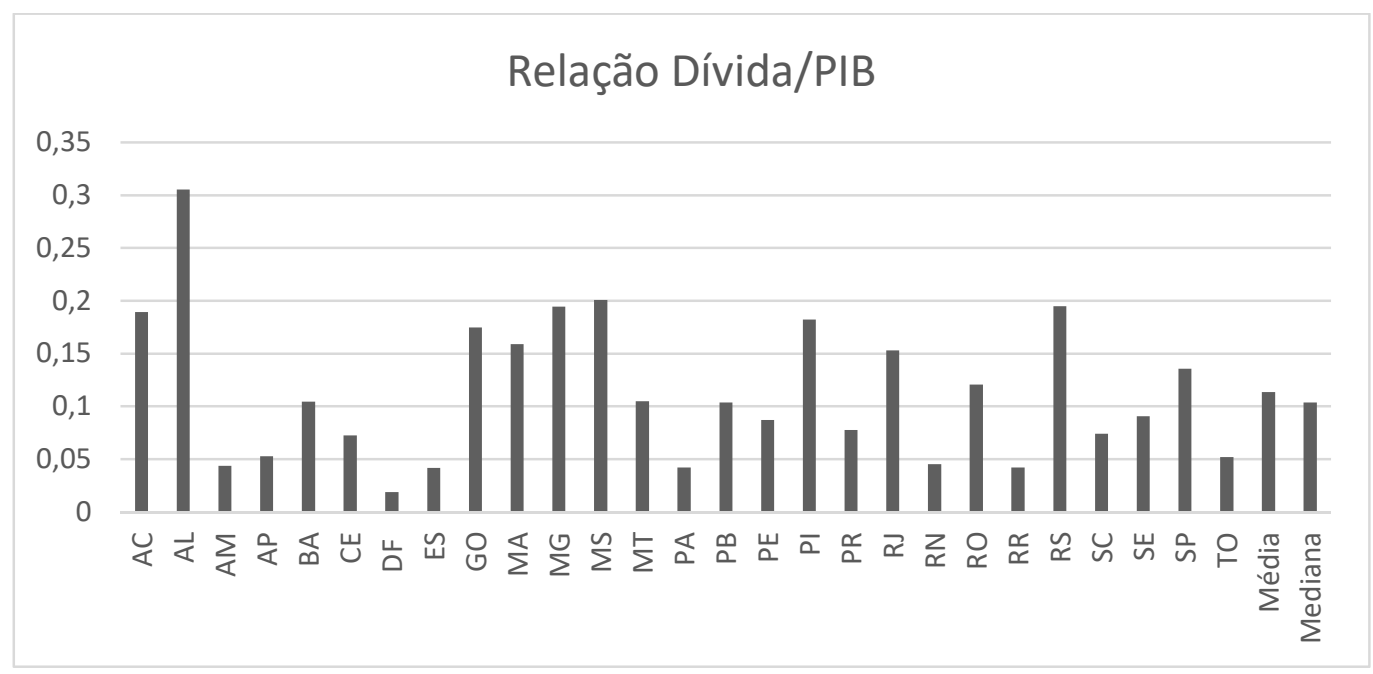

Fonte: Elaboração própria com dados do Relatório de Gestão Fiscal e IBGE

A partir da separação acima mencionada, estima-se o modelo 3, apresentado na tabela abaixo:

Tabela 9 - Modelo 3: Limite Endógeno

\begin{tabular}{ccc}
\hline Período & Dívida Líquida & Dívida Bruta \\
\hline Dívida Alta & & \\
\hline $2001-2015$ & $0.038240^{* * *}$ & $0.027143^{* * *}$ \\
& $(0.006412)$ & $(0.005908)$ \\
$2008-2015$ & 0.001393 & -0.012255 \\
& $(0.009357)$ & $(0.007714)$ \\
$2001-2020$ & $0.014085^{* * *}$ & 0.003600
\end{tabular}




\begin{tabular}{ccc} 
& $(0.004307)$ & $(0.003813)$ \\
$2008-2020$ & 0.009187 & 0.001067 \\
& $(0.007148)$ & $(0.005497)$ \\
\hline Dívida Baixa & & \\
\hline $2001-2015$ & $0.134437^{* * *}$ & $0.128796^{* * *}$ \\
& $(0.033385)$ & $(0.024581)$ \\
$2008-2015$ & $0.090963^{* *}$ & $0.073790^{* *}$ \\
& $(0.044740)$ & $(0.024154)$ \\
$2001-2020$ & $0.086832^{* * *}$ & $0.061481^{* * *}$ \\
& $(0.030462)$ & $(0.022181)$ \\
$2008-2020$ & 0.030376 & $0.024100^{*}$ \\
& $(0.023695)$ & $(0.014529)$
\end{tabular}

Fonte: Elaboração própria. Valores com ${ }^{* * *}$ indicam que a hipótese nula é rejeitada a um nível de $1 \%$ de significância. Valores com $\left({ }^{* *}\right)$ e $\left({ }^{*}\right)$ indicam, respectivamente, rejeição da hipótese nula a um nível de $5 \%$ e $10 \%$.

Para o período 2001 a 2015, o limite separador endógeno pareceu ser ineficaz, posto que, em ambos os grupos, o coeficiente é positivo e significante. Este resultado está em conformidade com o Modelo 1, em que foi estimado o painel completo. É uma sinalização que tanto os estados com uma relação de dívida alta quanto os com dívida baixa foram, como um todo, sustentáveis no período. No entanto, para o período 2008 a 2015, este limite é capaz de separar estados que, como um todo, não seguiram uma trajetória de dívida sustentável no período dos que seguiram uma trajetória sustentável. Para o grupo de dívida alta, o coeficiente para ambas as definições de dívida é não distinto de 0 . O grupo de dívida baixa, por sua vez, possui um coeficiente positivo e significante. O mesmo se pode dizer para o período 2000 a 2020. O limite endógeno conseguiu separar os estados que eram ou não sustentáveis na condução de sua política fiscal.

No entanto, para o período de 2008 a 2020, os estados são, como um todo, não sustentáveis em ambos os grupos. Não há, portanto, um equilíbrio separador. Note que, para efeitos de comparação, está sendo considerado o mesmo grupo de estados em todos os instantes do tempo. Este resultado parece indicar que haveria uma deterioração, dentro do período de 2016 a 2020, na condução da política fiscal 
dos estados de dívida baixa. Ambos os grupos de estados, como um todo, não seguiriam uma trajetória sustentável de endividamento.

Ainda assim, em dois horizontes temporais o limite endógeno foi capaz de gerar um equilíbrio separador entre os estados. No modelo 1, o painel completo, os estados seriam como um todo sustentáveis para o período 2000 a 2015 e não sustentáveis no período 2008 a 2020, sendo possivelmente este o motivo de o limite endógeno não ter gerado um equilíbrio separador.

Dada a discussão de como os mecanismos institucionais devem buscar tornarem exógenos e equânimes os limites e punições, resta ver se a estimação que toma por base a separação por motivações legais gera equilíbrios separadores. Isto é, é necessário testar se os mecanismos institucionais são capazes de punir todos aqueles estados que não seguem trajetórias sustentáveis da dívida, enquanto que eficientemente separa tais estados daqueles cuja política fiscal é sustentável.

O modelo 4 é que separa os estados a partir da sua relação gastos com pessoal do poder executivo sobre receita corrente líquida (GP/RCL). Como visto, a LRF estabelece três limites. O mais gravoso é o limite máximo, ultrapassado para os estados cuja relação GP/RCL seja maior que 49\%. Acre, Minas Gerais, Rio de Janeiro, Santa Catarina e Tocantins são os estados que ultrapassaram este montante ao fim de 2017. O segundo limite mais gravoso é o limite prudencial, válido para os estados cuja razão GP/RCL for maior que 46,55\%, que é o caso de Alagoas, Amazonas, Mato Grosso, Mato Grosso do Sul, Paraíba, Pernambuco, Piauí, Sergipe. Há também o limite de alerta, acionado quando a relação GP/RCL supera 44,1\%. Os estados de Distrito Federal, Pará, Paraná, Roraima e Rio Grande do Sul constam nesta categoria. Os demais estados:Amapá, Bahia, Ceará, Espírito Santo, Goiás, Maranhão, Rio Grande do Norte, Rondônia e São Paulo, não ultrapassaram nenhum desses limites ao fim de 2017, e logo não foram constrangidos às restrições e punições da LRF.

A estimação do modelo 4 separará a amostra nos quatro grupos de estados exposto anteriormente. Para que este mecanismo da LRF seja dito como válido, espera-se que os estados que quanto mais gravoso seja o limite de cada um dos estados, menor ou não significativo seja o coeficiente de reação fiscal. Os resultados estão apresentados na tabela seguinte: 
Tabela 10 - Modelo 4: Gastos com Pessoal sobre Receita Corrente Líquida

\begin{tabular}{|c|c|c|}
\hline Período & Dívida Líquida & Dívida Bruta \\
\hline \multicolumn{3}{|l|}{ Máximo } \\
\hline \multirow[t]{2}{*}{ 2001-2015 } & 0.029469 & 0.024664 \\
\hline & 0.020024 & 0.028230 \\
\hline \multirow[t]{2}{*}{$2008-2015$} & -0.033396 & $-0.033377^{*}$ \\
\hline & 0.018803 & 0.012101 \\
\hline \multirow[t]{2}{*}{$2001-2020$} & -0.007266 & 0.007829 \\
\hline & 0.007631 & 0.020821 \\
\hline \multirow[t]{2}{*}{$2008-2020$} & -0.010918 & -0.012160 \\
\hline & 0.013557 & 0.009217 \\
\hline \multicolumn{3}{|l|}{ Prudencial } \\
\hline \multirow[t]{2}{*}{$2001-2015$} & $0.048101^{* \star *}$ & 0.035747 \\
\hline & 0.005372 & 0.005348 \\
\hline \multirow[t]{2}{*}{ 2008-2015 } & $0.032133^{* * *}$ & $0.015135^{*}$ \\
\hline & 0.009254 & 0.007625 \\
\hline \multirow[t]{2}{*}{$2001-2020$} & $0.034900^{* * *}$ & $0.022250^{* * *}$ \\
\hline & 0.004923 & 0.005322 \\
\hline \multirow[t]{2}{*}{$2008-2020$} & $0.023041^{\star \star *}$ & 0.008837 \\
\hline & 0.007910 & 0.007086 \\
\hline \multicolumn{3}{|l|}{ Alerta } \\
\hline \multirow[t]{2}{*}{ 2001-2015 } & 0.053587 & $0.085979^{* * *}$ \\
\hline & 0.038627 & 0.028641 \\
\hline \multirow[t]{2}{*}{$2008-2015$} & 0.035878 & $0.074754^{* * *}$ \\
\hline & 0.036666 & 0.020637 \\
\hline \multirow[t]{2}{*}{$2001-2020$} & 0.045065 & 0.029140 \\
\hline & 0.031873 & 0.024904 \\
\hline \multirow[t]{2}{*}{$2008-2020$} & 0.030477 & $0.047338^{* * *}$ \\
\hline & 0.020228 & 0.013849 \\
\hline
\end{tabular}

Demais Estados

2001-2015 $0.115358^{* * *} \quad 0.102243^{* * *}$




$\begin{array}{lll} & 0.032177 & 0.030276 \\ 2008-2015 & 0.070501 & 0.054001 \\ & 0.047188 & 0.038623 \\ 2001-2020 & 0.057714 & 0.041984 \\ & 0.036109 & 0.028287 \\ 2008-2020 & 0.027046 & 0.002372 \\ & 0.025344 & 0.019776\end{array}$

Fonte: Elaboração própria. Valores com $\left(^{* * *}\right)$ indicam que a hipótese nula é rejeitada a um nível de $1 \%$ de significância. Valores com $\left({ }^{* *}\right)$ e $\left(^{*}\right)$ indicam, respectivamente, rejeição da hipótese nula a um nível de $5 \%$ e $10 \%$.

Considerando o período 2001 a 2015, nota-se que o coeficiente de reação é significativo e significante apenas para os grupos de estados que estão no limite de alerta e o grupo de estados que não ultrapassaram nenhum limite. Aparentemente, o mecanismo legal é funcional para o período, posto que as punições mais severas estão sendo aplicadas sob os estados que não seguem uma trajetória de dívida sustentável. Não obstante, o coeficiente do grupo "demais estados" é superior ao do grupo "alerta", um indicativo de que o grupo que não está sujeito às limitações da LRF é aquele cuja trajetória de dívida seria mais sustentável.

Quando considerado apenas o período 2008 a 2015, o cenário se altera. percebe-se que apenas os estados que estão no limite de alerta são sustentáveis. Logo, este é um indicativo de que há estados que estão no grupo "demais estados", que não estão sujeitos a nenhum tipo de punição ou impedimento quanto a seus gastos, que não seguem uma trajetória sustentável de sua dívida, enquanto os estados que estão no limite de alerta, relativamente mais gravosos, são sustentáveis em sua trajetória de dívida. Este resultado corrobora duas teses anteriormente citadas. A primeira é de que os controles de restrição ao endividamento estadual foram relaxados depois da crise de 2008, dado que o grupo "demais estados", quando considerado o período de 2001 a 2015 seguia uma política fiscal sustentável, e não mais a segue quando analisados apenas 2008 a 2015. A segunda tese é a de que há a tentativa dos estados de burlar os mecanismos legais, valendo-se, por exemplo, da definição vaga de gastos com pessoal. Assim, enquanto o grupo de estados "alerta" segue uma política fiscal sustentável, o grupo que sequer é afetado pela LRF não segue uma trajetória equilibrada de sua dívida. 
Para o período de 2001 a 2020, apenas os estados que ultrapassaram o limite prudencial aparentam seguir uma política fiscal sustentável. O coeficiente de reação dos demais grupos não é estatisticamente distinto de zero. A grande implicação deste resultado é que ele reforça indiretamente a ideia do comportamento de risco moral que não consegue ser controlado pelo dispositivo legal. Há um conjunto de estados que não segue uma política fiscal sustentável e que não são punidos pela LRF. Isto gera um incentivo aos estados em se endividarem excessivamente, com a expectativa de que serão resgatados pela União.

Quando considerado o período 2008 a 2020, o resultado é análogo aquele discutido para o período de 2008 a 2015: são sustentáveis apenas os estados que estão no limite de alerta, um demonstrativo de que há estados cuja trajetória da dívida não é sustentável, mas que não são punidos pela LRF, enquanto estados que são sustentáveis são punidos.

A partir dos resultados obtidos, infere-se que, em todos os períodos amostrais retratados, os mecanismos institucionais não foram capazes de gerar equilíbrios separadores. Em 2001 a 2015, os grupos de estados que ultrapassaram o limite de alerta e os estados que não ultrapassaram nenhum limite são aqueles que obtiveram coeficientes positivos e estatisticamente distintos de zero. Para os demais períodos, o grupo de estados para os quais a lei não prevê qualquer punição foram sempre não sustentáveis com sua política fiscal, com algum grupo de estados que estariam sujeitos a restrições apresentando uma política fiscal sustentável. Logo, a lei estaria punindo, em diferentes recortes temporais, grupos de estados que estariam seguindo uma política fiscal sustentável, enquanto nada faz para grupos de estados que não seguiriam uma política fiscal sustentável. Comparativamente à situação do modelo 3 , há ineficiência quanto ao objetivo do instrumento punitivo.

Como foi discutido anteriormente, é possível que os estados estariam se aproveitando do fato de que a LRF não estabelece claramente o que seriam gastos com pessoal. Como esta definição é vaga, é possível que, a partir de um certo ponto em que seriam punidos pela LRF, os estados considerassem que o aumento de gastos com, por exemplo, vale alimentação, não era despesa com pessoal, mas despesa com custeio, que não sofre nenhum limite pela LRF. Isto justificaria haver estados que não estão sujeitos à nenhuma punição institucional, mas que não possuem uma trajetória da dívida sustentável. 
O caminho para tornar este mecanismo mais eficiente seria o de se determinar uma definição precisa do que seria o gasto com pessoal, resultado que alteraria a relação GP/RCL de cada estado e a composição de cada um dos grupos. Esta reforma, como outras que se relacionam com a ampliação do rigor com a despesa estadual com pessoal, foram rejeitadas pelos governadores. A reestimação com base neste eventual novo grupo indicaria se este, agora, seria um mecanismo eficiente.

Outro mecanismo institucional é a Resolução no. 40 do Senado Federal, de 2001, também relacionado à LRF, que estipula que a relação dívida consolidada líquida dos estados sobre receita corrente líquida ( $D C L / R C L)$ não pode ultrapassar $200 \%$. Caso um estado ultrapasse este limite, este deverá ser reconduzido abaixo do limite em até um ano. Enquanto esta situação permanecer, o estado estará sujeito à punições como proibição de realizar operações de crédito, exceto para refinanciamento do principal atualizado da dívida mobiliária e proibição de receber transferências voluntárias.

Ao fim de 2017, eram três os estados cuja relação DCL/RCL superava os $200 \%$ - Minas Gerais, Rio de Janeiro e Rio Grande do Sul. Os demais estados não estavam sujeitos às punições da resolução. O modelo 5 é aquele, então, que separa estes dois grupos de estados. Os resultados estão apresentados na tabela que segue:

Tabela 11- Modelo 5: Relação DCL/RCL

\begin{tabular}{lll}
\hline Período & Dívida Líquida & Dívida Bruta \\
\hline Maior que 2 & & \\
\hline $2001-2015$ & $0.019254^{* * *}$ & $0.013116^{* * *}$ \\
& 0.004153 & 0.004603 \\
$2008-2015$ & 0.004098 & -0.005340 \\
& 0.007125 & 0.007605 \\
$2001-2020$ & 0.001014 & -0.002012 \\
& 0.006570 & 0.003670 \\
\hline $2008-2020$ & -0.005366 & -0.005966 \\
& 0.008438 & 0.008021 \\
\hline Menor que 2 & & \\
\hline 2001-2015 & $0.066144^{* * *}$ & $0.062473^{* * *}$ \\
\hline
\end{tabular}




$\begin{array}{lll} & 0.014390 & 0.012780 \\ 2008-2015 & 0.017158 & 0.018218 \\ & 0.018193 & 0.013975 \\ 2001-2020 & 0.037800^{* * *} & 0.030733^{* * *} \\ & 0.013037 & 0.012536 \\ 2008-2020 & 0.021357 & 0.012995 \\ & 0.010736 & 0.008339\end{array}$

Fonte: Elaboração própria. Valores com $\left(^{* * *}\right)$ indicam que a hipótese nula é rejeitada a um nível de $1 \%$ de significância. Valores com $\left({ }^{* *}\right)$ e $\left({ }^{*}\right)$ indicam, respectivamente, rejeição da hipótese nula a um nível de $5 \%$ e $10 \%$.

Os resultados parecem apontar que não há equilíbrio separador para este modelo, a partir do limite de $200 \%$ da relação DCL/RCL, para a maioria dos recortes temporais. Isto porque, de uma forma geral, os dois grupos de estados comportam-se de maneira similar nos períodos analisados.

Para o período de 2001 a 2015, os estados como um todo seguiram uma trajetória sustentável de sua dívida em ambos os grupos, posto que os coeficientes são positivos. No horizonte de 2008 a 2015, os coeficientes de reação não são significantes para ambos os grupos, um indicativo de que os estados não seguiriam uma política fiscal sustentável no período em ambos os grupos. Estes dois resultados corroboram aquele encontrado no modelo 1.

Já no período de 2001 a 2020, no entanto, ocorre a separação. Enquanto o grupo de estados cuja relação DCL/RCL é menor que 2 segue uma política fiscal sustentável no período, o inverso se diz do outro grupo. Este resultado, no entanto, não sinaliza que o dispositivo institucional esteja sendo capaz de frear o comportamento potencialmente abusivo dos estados. Do modelo 1 , infere-se que os estados, como um todo, seguiriam uma trajetória sustentável de endividamento. Logo, a Resolução de número 40 do Senado Federal não estaria separando os estados sustentáveis do todo, mas sim separando alguns dos estados não sustentáveis do todo. A justificativa seria de que apenas o limite de $200 \%$ acabaria tentando separar os estados em um patamar já elevado. A intuição é a de que se há um estado que está caminhando para o limite de $200 \%$ a um ritmo relativamente rápido, então este estado provavelmente já não segue uma trajetória sustentável de endividamento. No entanto, ele não será constrangido pela Resolução 40 . O mecanismo do modelo 4 
previa três distintos níveis de gradação da relação GP/RCL, com medidas cada vez mais gravosas. O mesmo poderia ser feito em relação a este mecanismo. Como a definição tanto da dívida consolidada líquida e da receita corrente líquidas, é dificultada a postura que os estados parecem ter no modelo 4, de se aproveitar da imprecisão conceitual para aumentar os seus gastos, um comportamento claramente de risco moral.

Por fim, no último período, de 2008 a 2020, os resultados sinalizam que as trajetórias de dívida dos estados não são sustentáveis em ambos os grupos. Novamente, não há distinção entre os grupos, o limite legal não é capaz de separar os estados em sua qualidade de reação fiscal.

Os resultados do modelo 4 e 5 apontam que os mecanismos legais não são capazes de punir os estados que não seguem uma trajetória sustentável da dívida. Em alguns casos, pune estados que seguem trajetórias sustentáveis e frequentemente não constrange estados cuja política fiscal não é equilibrada. Estes mecanismos, portanto, são ineficientes em punir apenas os estados que não seguem uma política fiscal responsável.

Desta forma, a tese de que os estados seguem um comportamento de risco moral, endividando-se acima do que seria o ótimo, assumindo que o ônus deste comportamento será assumido pela União, está em conformidade com os resultados apresentados nesta seção. 


\section{CONCLUSÃO}

A Lei Complementar de número 156, sancionada em 28 de dezembro de 2016, autorizou a renegociação das dívidas estaduais pela União, alongando-as por vinte anos, após uma rodada de discussões e de pressões políticas que se iniciaram anos antes.

Este acontecimento poderia ter caráter cotidiano, pois seria previsível que os estados estivessem em dificuldade fiscal, dada a crise que se instalou no país desde 2014, que resultaram em receitas deprimidas.

No entanto, a lei 9.496, de 1997, encerrava uma série de refinanciamentos da dívida estadual pela União. Como contrapartida à ajuda federal, os estados se comprometiam a seguir uma cartilha de boas práticas fiscais, com estipulação de metas e compromissos para a divida consolidada, resultado primário, despesa com pessoal, dentre outros, que seriam, ao fim do período, avaliadas pelo próprio estado e pelo Ministério da Fazenda, A Lei Complementar de número 101, de 2000, completou este ciclo de busca de responsabilidade fiscal pelos entes, nome pelo qual ficou conhecida a lei.

Logo se percebe que os dispositivos legais não se encaixam. Se a lei $9.496 \mathrm{e}$ a Lei de Responsabilidade Fiscal (LRF) trouxeram como objetivo a gestão fiscal prudente, transparente e eficiente, circunscrevendo o espaço de política fiscal dos estados, por que surgiu a necessidade de, pouco menos de vinte anos depois, realizar um novo refinanciamento? É possível que os mecanismos criados por essas leis não tenham sido capazes de frear o comportamento dos governantes, de procurar realizar uma política fiscal não sustentável, com a expectativa de no futuro seremperdoados pela União e, ainda assim, garantindo os benefícios políticos deste endividamento excessivo?

Esta dissertação buscou responder estes questionamentos. Utilizando-se da metodologia de Bohn (1998), estimou-se a função de reação fiscal. Como demonstra o autor, se o coeficiente associado à dívida do período anterior for positivo, então o ente em questão possui uma política fiscal sustentável, pois a relação dívida/PIB terá reversão à média. 
Estimou-se a função de reação fiscal para o painel de estados brasileiros. A estimação se pautou em cinco modelos: o painel completo, a separação por regiões, a separação pelo limite endógeno proposto em Mendoza e Ostry (2008), a separação pelos critérios de gastos com pessoal da LRF e a separação pela relação dívida consolidada líquida sobre o PIB. Em todos estes modelos, houve quatro recortes temporais: 2001 a 2015, 2008 a 2015, 2001 a 2020 e 2008 a 2020. A justificativa do recorte em 2008 é a de que assim seria possível testar a hipótese de que os controles ao endividamento foram relaxados como estratégia para enfrentar a crise de 2008. Por fim, em cada modelo e em cada recorte temporal, foram consideradas as dívidas consolidadas brutas e líquidas dos estados.

Os resultados obtidos da estimação do modelo 1 sugerem que tanto entre 2001 e 2015 quanto entre 2001 e 2020 os estados seguiram uma trajetória sustentável. No entanto, quando são considerados apenas os anos após a crise de 2008, este resultado se inverte: a política fiscal dos estados não seria equilibrada. Logo, a tese de que os controles ao endividamento foram relaxados após a crise está em consonância com o resultado encontrado.

A estimação, considerando a separação regional, tem a finalidade de tornar o resultado encontrado no modelo 1 menos homogêneo. Ainda que o resultado para o período de 2001 a 2015 seja o mesmo encontrado no modelo anterior, observa-se que os estados da região sul, como um todo, foram sustentáveis nos demais períodos, o que difere do primeiro modelo. No período de 2001 a 2020, também, os estados da região Nordeste realizaram uma política fiscal sustentável.

O modelo 3 inaugura a tentativa de se identificar um critério que fosse capaz de separar os estados que seguiriam uma trajetória equilibrada de endividamento e os que não seguiriam. O critério se baseia em Mendoza e Ostry (2008), e separa endogenamente os grupos em 2: dívida alta e baixa. Dado o painel de estados, aqueles cuja relação dívida consolidada líquida/PIB for maior que o valor médio e da mediana deste índice no painel estarão no grupo de dívida alta, e o restante no grupo dívida baixa. Este critério foi capaz de gerar um equilíbrio separador para os períodos de 2008 a 2015 e para 2001 a 2020.

A estimação do modelo 4 testa se os mecanismos da LRF para a relação gasto com pessoal sobre o produto geram equilíbrios separadores, em que são punidos os 
estados cuja política fiscal é não sustentável, e estados que não estão sujeitos à coerção institucional são aqueles cuja trajetória da dívida é balanceada. A separação dos estados se deu com base nos limites estabelecidos pela lei: alerta, prudencial, máximo e demais estados, este último reunindo os estados não afetados pela LRF. Os resultados indicam que a LRF não é capaz de gerar equilíbrios separadores: estados que por ela não são afetados não seguem uma política fiscal equilibrada. Por vezes, estados que estavam no limite de alerta ou prudencial, logo em situação mais gravosa, seguiam políticas fiscais sustentáveis, enquanto aqueles que não eram punidos pela lei eram insustentáveis em seu endividamento.

A ineficiência do mecanismo analisado no modelo 4 pode ter relação com o fato de que a LRF não define claramente o que são gastos com pessoal. Logo, alguns estados podem alegar que os seus gastos com benefícios trabalhistas são gastos com custeio, que não são limitados pela LRF. Este processo permite o aumento dos gastos sem que haja constrangimento por tal lei.

Por fim, o modelo 5 testa se o critério estabelecido na Resolução 40 do Senado Federal gera um equilíbrio separador. Segundo esta resolução, a relação dívida consolidada líquida sobre receita corrente líquida ( $D C L / R C L)$ não pode ultrapassar $200 \%$. Separando os estados entre aqueles que ultrapassaram esta relação e os demais, observa-se que, novamente, não há um equilíbrio separador. Na maioria dos recortes temporais, a magnitude do coeficiente de reação fiscal é a mesma. Apenas no período de 2001 a 2020 ocorre uma separação: o grupo de estados cuja relação supera 2 não apresenta uma trajetória sustentável de endividamento, enquanto os demais estados possuem. Do modelo 1, tem-se que os estados, como um todo, seriam sustentáveis neste período. O limite é ineficiente pois separa alguns estados irresponsáveis do conjunto total, no lugar de separar os estados sustentáveis do resto dos estados. Logo, pode ser que ainda exista algum estado cuja política fiscal não é sustentável que não está sendo constrangido por punições.

O mecanismo analisado parece não ser eficiente pois estabelece um único limite relativamente alto para estabelecer a punição. Logo, não é capaz de captar um estado cuja relação $\mathrm{DCL} / \mathrm{RCL}$ é inicialmente baixa, mas cujo desequilíbrio na condução da política fiscal leva a uma acelerada elevação. Durante um período de tempo, este estado poderá seguir uma política fiscal insustentável sem que seja 
punido. Uma possível solução passaria pela aproximação ao modelo 4, em que há mais de um limite separador em que há punições gradativas.

Os resultados, como um todo, sinalizam que os principais instrumentos de controle ao processo de endividamento estatal não são eficientes. Se um governador enxergar que a União sempre aceitará refinanciar as suas dívidas, então preferirá seguir uma política fiscal insustentável, pois terá o benefício político de aumentar seus gastos até mesmo em interesses da população de seu estado, com o custo fiscal assumido pela União, isto é, pela sociedade, tanto pela redução da dotação de recursos que atenderia o interesse de todos, quanto pela perda de credibilidade internacional que sofreriam os títulos nacionais.

Assim, se há este problema de risco moral por parte dos estados, cabe a União frear este comportamento. Os mecanismos institucionais do fim da década de 90, por si só, não são eficientes. Quando houve, em 2016, a tentativa federal de se formalizar a definição de gastos com pessoal, bem como de se exigir a criação de uma lei estadual de responsabilidade fiscal, dentre outros, como contrapartida para a renegociação de suas dívidas, os governadores não aceitaram. Ainda assim, a renegociação prosseguiu e os estados foram ajudados. Este comportamento da União acaba por reforçar a importância relativa dos estados no aspecto político, o que fortalece o comportamento abusivo dos estados.

Portanto, somente uma União que tenha credibilidade será capaz de frear o comportamento de risco moral dos estados. Esta credibilidade é sustentada por instrumentos políticos, mas também institucionais e legais. Os dispositivos criados quando da renegociação de 1997, ainda que virtuosos, são ineficientes. Se reformas institucionais e legais não forem feitas para corrigi-los e aprimorá-los, esta não será a última renegociação das dívidas estaduais. 


\section{Referências Bibliográficas}

ALESINA, A.; TABELLINI, G. A positive theory of fiscal deficits and government debt. The Review of Economic Studies. v.47, n.3, p. 403-414, 1990.

BAI, J.; PERRON, P. Estimating and testing linear models with multiple structural changes. Econometrica. v. 66, p. 47-78, 1998.

BENDER, S.; NAKAGUMA, M. Y. A emenda da reeleição e a Lei de Responsabilidade Fiscal: impactos sobre ciclos políticos e a performance fiscal dos estados (1986-2002). Economia Aplicada, v.10, n.3. Ribeirão Preto, jul.-set. 2006.

BICALHO, A. Teste de sustentabilidade e ajuste fiscal no Brasil pós-real. Fundação Getúlio Vargas, Escola Brasileira de Economia e Finanças, dissertação de mestrado, 2005.

BLANCHARD, O. Sugestions for a New Set of Fiscal Indicators. OECD Working Paper n.79, 1990.

BOHN, H. The behavior of U.S. public debt and deficits. Quarterly Journal of Economics. v. 113, p.949-963, 1998.

$\mathrm{BOHN}, \mathrm{H}$. Are stationarity and cointegration restrictions really necessary for the intertemporal budget constraint? Journal of Monetary Economics. V. 54(7), p. 183747, 2007.

BOHN, H. The sustainability of the fiscal policy in the United States. In (R. Neck e J.E. Sturm, eds). Sustainability of Public Debt. p. 15-49. Cambridge. MA: MIT Press, 2008.

BUGARIN, M. S. Renegociação de dívidas e eleições: Experimentação e reputação na política fiscal após o programa de ajuste fiscal dos estados e municípios. XXV Encontro Brasileiro de Econometria, João Pessoa, 2004.

BURGER, Philippe et al. Fiscal sustainability and the fiscal reaction function for South Africa. IMF Working Papers. p. 1-27, 2011.

CHICOLI, R. S. Sustentabilidade da dívida pública brasileira: Uma análise sob diversos conceitos de superávit primário e endividamento. 2015. 87 f. Tese (Mestrado em Economia) - Instituto de Pesquisas Econômicas, Universidade de São Paulo, São Paulo. 2015.

CLAEYS, P.; RAMOS, R.; SURIÑACH, J. Fiscal sustainability across government tiers.International Economics and Economic Policy, v. 5(1), p. 139-163, 2008.

D'ERASMO, P.; MENDOZA, E. G.; ZHANG, J. What is a sustainable public debt? NBER Working Paper No. 21574, 2015.

ENGLE, R. F.; GRANGER, C. W. Co-integration and error correction: representation, estimation and testing. Econometrica, v.55, n.2, p. 251-276, 1987. 
ENGLE, R. F.; YOO, B. S. Forecasting and testing in co-integrated systems. Journal of Econometrics. n. 1, v. 35, p. 143-159, 1987.

FINCKE, B.; GREINER, A. Debt Sustainability in Selected Euro Area Countries: Empirical Evidence Estimating Time-Varying Parameters.Studies in Nonlinear Dynamics and Econometrics.15(3). 2011.

FINCKE, B.; GREINER, A. Debt sustainability in Germany: empirical evidence for federal states. International Journal of Sustainable Economy. v.3(2), p. 235-254, 2011.

FLAVIN, M.; HAMILTON, J. On the limitations of government borrowing: A framework for empirical testing. American Economic Review. n. 76, p. 808-819, 1986.

FONTENELE, A.L. et al. Sustentabilidade da dívida pública dos estados brasileiros. Revista Ciências Administrativas. Fortaleza, v.21, n.2 p.621-638, jul./dez. 2015.

FUNDO MONETÁRIO INTERNACIONAL. Assessing Sustainability. Washington. 2002.

GOLDFAJN, I. Há razões para duvidar que a dívida pública no Brasil é sustentável? Notas Técnicas do Banco Central do Brasil. v. 25, p. 251-260, 2002.

GHOSH, Atish R., KIM, J. I., MENDOZA, O. G., OSTRY, J. D., QURESHI, M. S. Fiscal fatigue, fiscal space and debt sustainability in advanced economies. The Economic Journal. v. 123, n. 566, p. F4-F30, 2013.

GREINER, A.; KÖLLER, U.; SEMMLER W. Debt sustainability in the European Monetary Union: Theory and empirical evidence for selected countries. Oxford Economic Papers. Oxford, 59(2), p. 194-218, 2007.

HAKKIO, C.; RUSH, M. Is the budget deficit "too large?". Economic Inquiry. n. 29, p.429-445, 1991.

IM, K. S.; PESARAN, H.; SHIN, Y. Testing for unit roots in heterogeneous panels. Journal of Econometrics, v.115, p.53-74, 2003.

ISSLER, J. V.; LIMA L. R. Public debt sustainability and endogenous seigniorage in Brazil: time-series evidence from 1947-1992. Journal of Development Economics. v. 62 , p. 131-147, 2000.

JOHANSEN, S. Estimation and Hypothesis Testing of Cointegration Vectors in Gaussian Vector Autoregressive Models. Econometrica , v.59 no.6, p. 1551-1580, 1991.

LOPREATO, F. L. C.; Federalismo e finanças estaduais: algumas reflexões. Instituto de Economia/UNICAMP. n.98, set. 2000.

LUPORINI, V. The behavior of the Brazilian federal domestic deficit. Texto para discussão. CEDEPLAR/UFMG. n. 161, p. 1-16, 2001.

LUPORINI, V. Sustainability of Brazilian fiscal policy, once again: corrective policy 
response over time. Estudos Econômicos. São Paulo, v.45, no.2, abr./jun. 2015.

MACIEL, P. J. Despesas de Pessoal e a LRF. Valor Econômico. São Paulo, 10 jun. 2016.

MADDALA, G. S.; WU, S. A comparative study of unit root tests with panel data and a new simple test. Oxford Bulletin of Economics and Statistics, v.61, p.631-652, 1999.

MELLO, L. Estimating a fiscal reaction function: the case of debt sustainability in Brazil. Applied Economics. v.40, p. 271-84, 2008.

MENDONÇA, M.; SANTOS, C.; SACHSIDA, A. Revisitando a função de reação fiscal no Brasil pós-Real: Uma abordagem de mudanças de regime. Estudos Econômicos. v. 39, n. 4, p.873-894, 2009.

MENDOZA, E. G.; OSTRY, J. D. International evidence on fiscal solvency: Is fiscal policy "responsible"? Journal of Monetary Economics. v.55, p. 1081-1093, 2008.

MORA, M. Federalismo e dívida estadual estadual no Brasil (Texto para Discussão n.866), Instituto de Pesquisa Econômica Aplicada, Rio de Janeiro, mar. 2002.

MORA, M.; GIAMBIAGI, F. Federalismo e endividamento subnacional: uma discussão sobre a sustentabilidade da dívida estadual. Revista de Política Econômica, vol. 27 , n.3 (107), p. 474-494, jul./set. 2007.

MORA, M. et al. Finanças Públicas Estaduais (Carta de Conjuntura 39). Instituto de Pesquisa Econômica Aplicada. Rio de Janeiro, 2018.

PEDRONI, P.; Critical values for cointegration tests in heterogeneous panels with multiple regressors. Oxford Bulletin of Economics and Statistics, v.61, n.4, p.653670, 1999.

PEDRONI, P.; Panel cointegration; asymptotic and finite samples properties of pooled time series with an application to the purchasing power parity hypothesis. Econometric Theory, v. 20, p. 597-625, 2004.

PIANCASTELLI, M.; BOUERI, R. Dívida dos Estados 10 anos depois (Texto para Discussão n.1366). Instituto de Pesquisa Econômica Aplicada, Rio de Janeiro, dez. 2008.

POTRAFKE, Niklas; REISCHMANN, Markus. Fiscal transfers and fiscal sustainability. CESifo Working Paper. n. 4716, 2014.

RIGOLON, F. J. Z.; GIAMBIAGI, F.; A renegociação das dívidas e regime fiscal dos estados. A economia brasileira nos anos 90. 1. ed, p. 111-144. Rio de Janeiro, 1999.

ROCHA, F. Long-run limits on the Brazilian government debt. Revista Brasileira de Economia. n.51, p. 447-470, 1997.

SAIKKONEN, P. Estimation and testing of cointegrated systems by an autoregressive approximation. Econometric Theory, v.8, n.1, p.1-27, 1992. 
SARGENT, T.; WALLACE, N. Some unpleasant monetarist arithmetic. Federal Reserv Bank of Minneapolis. Quarterly Review. v. 5, n. 3, p. 1-17, 1981.

SIMONASSI, Andrei G.; ARRAES, Ronaldo A.; DE SENA, Augusto Marcos C. Fiscal reaction under endogenous structural changes in Brazil. EconomiA. 2014.

SILVA, I. F. B. R.; SOUSA, M. C. S. Determinantes do endividamento dos estados brasileiros: uma análise de dados de painel. Departamento de Economia/Universidade de Brasília, 2002.

STOCK, J. H.; WATSON, M.W. A simple estimator of cointegrated vectors in higher order integrated systems. Econometrica. v.61, n.4, p.783-820, 1993.

TABOSA, F. J. S. et al. Reação fiscal ao aumento da dívida pública: uma análise para os estados brasileiros. Economia Aplicada, v.21, n.1, p.57-71, 2016.

TREHAN, B.; WALSH, C. Common trends, the government budget constraint, and revenue smoothing. Journal of Economic Dynamic and Control. v. 12, p. 425-444, 1988.

VELLOSO, R. Como a união fomentou a crise dos estados. O GLOBO, Rio de Janeiro, 14 dez. 2015.2 Disponível em: <http://noblat.oglobo.globo.com/artigos/noticia/2015/12/como-uniao-fomentou-crisedos-estados.html> Acesso em 31 mai. 2018. 
ANEXO A - GRÁFICO DAS VARIÁVEIS DE INTERESSE POR CROSS-SECTION 1 - Resultado primário como proporção do PIB (2001-2015)

$R P P \mid B$
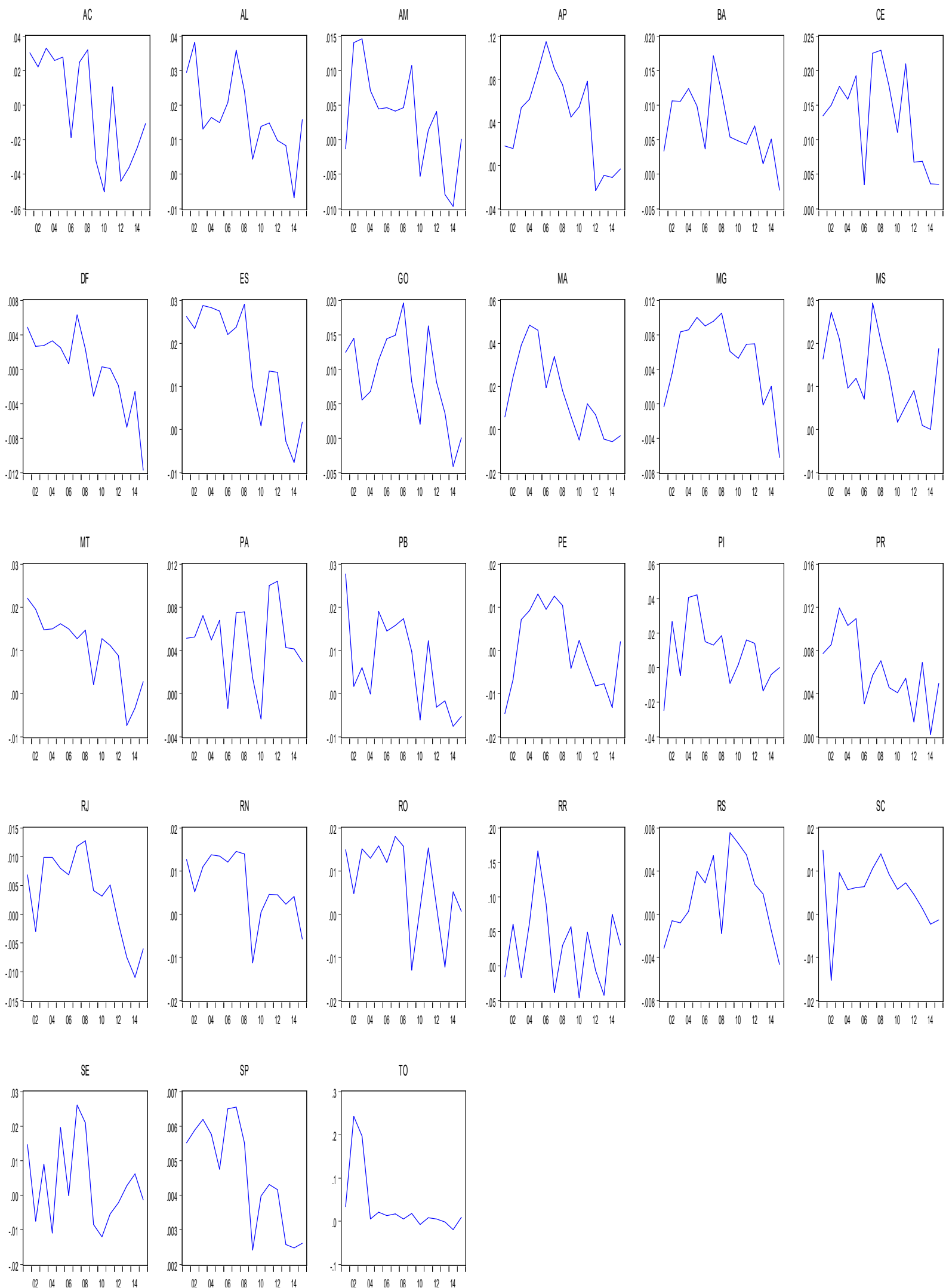


\section{2 - Dívida consolidada líquida como proporção do PIB (2001-2015)}

DCLPPB

AC

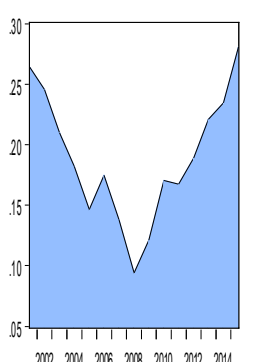

DF
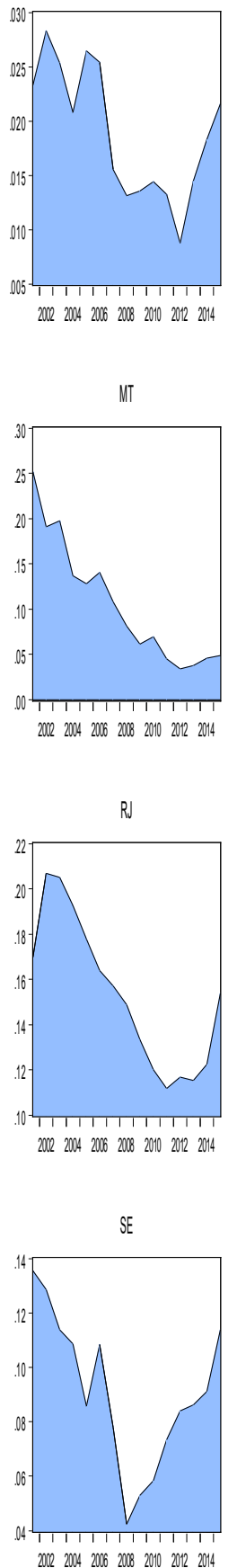

Al
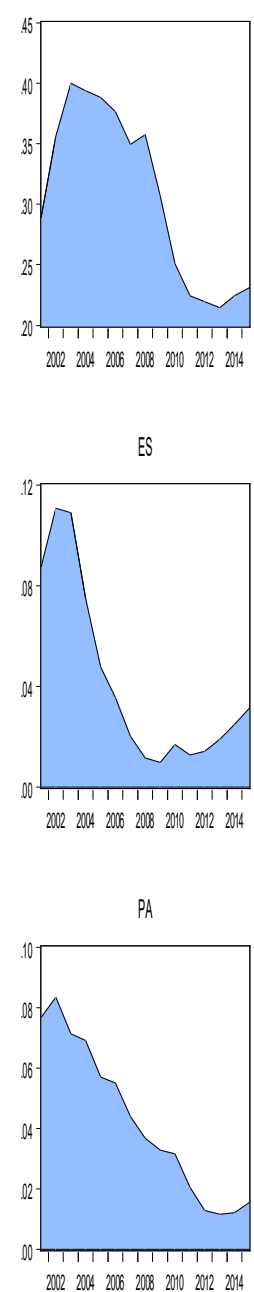

RN

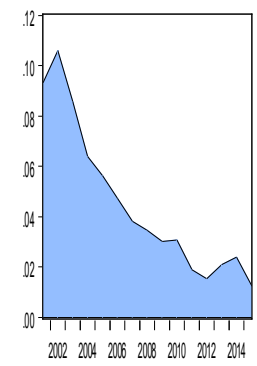

$S P$

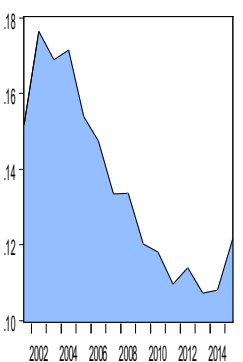

AM

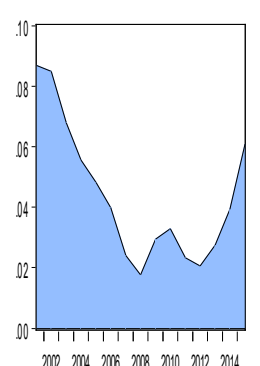

GO

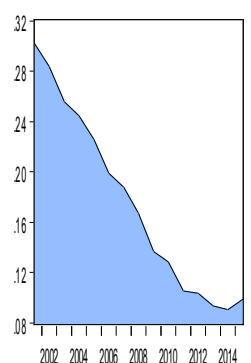

PB

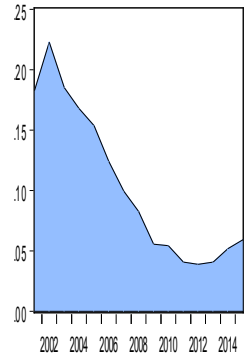

RO

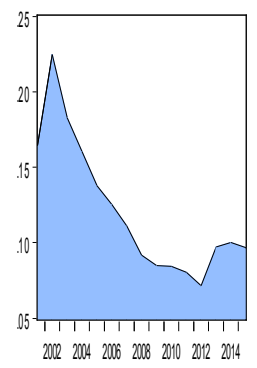

TO

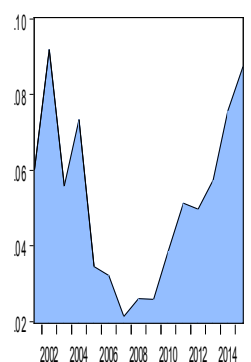

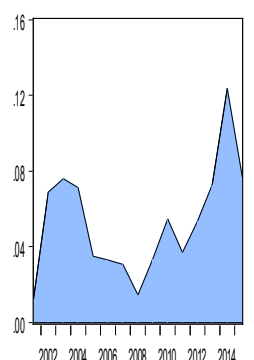
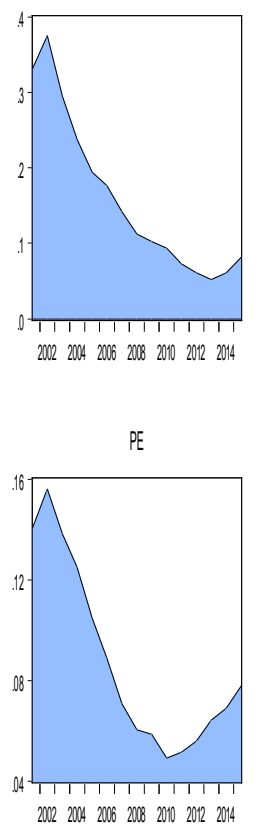

RR

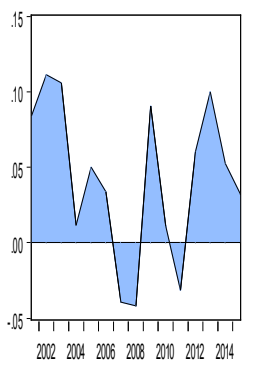

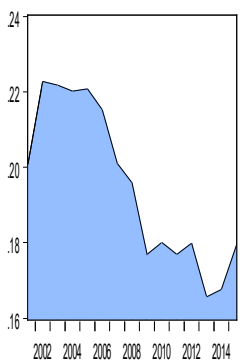

$B A$

CE

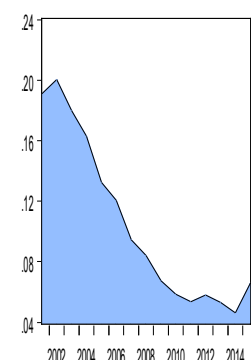

MG
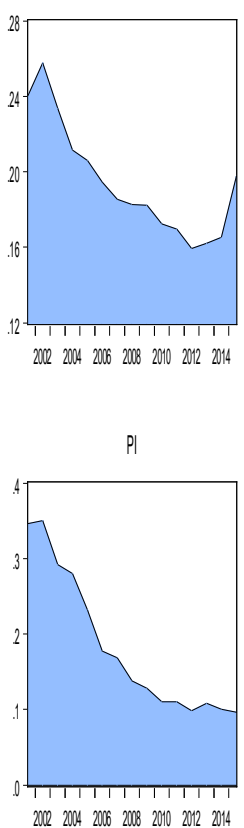

2002200420062008201020122014

MS

$P R$
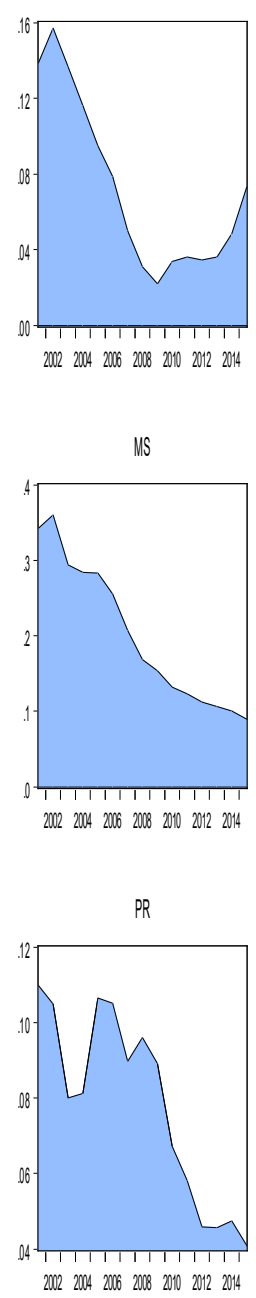

SC

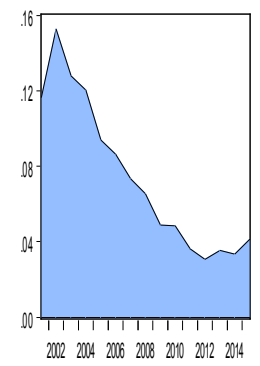




\section{3 - Dívida consolidada bruta como proporção do PIB (2001-2015)}

DCPBB

AC

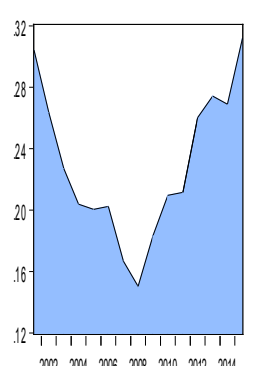

DF

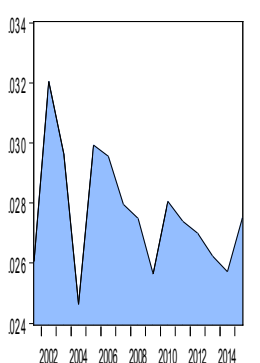

MT

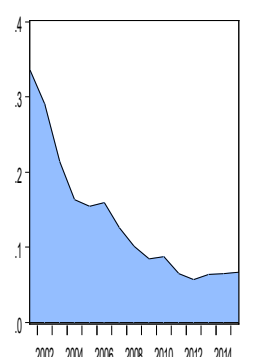

RJ

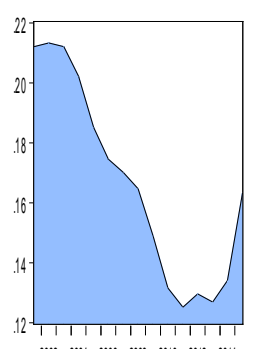

2002200420062008201020012004

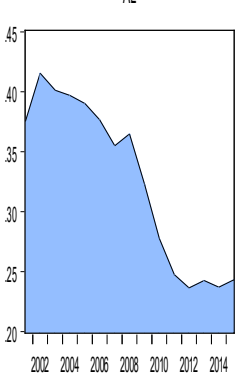

ES

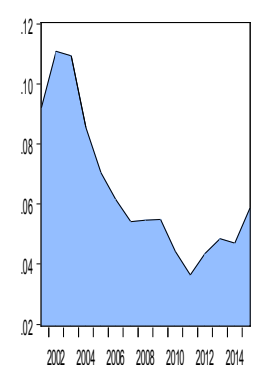

PA

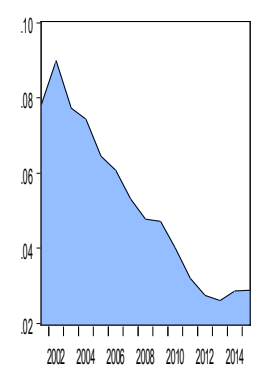

RN

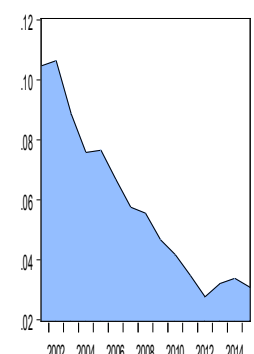

SP

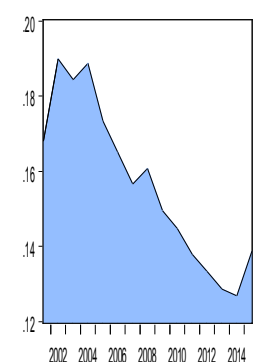

AM

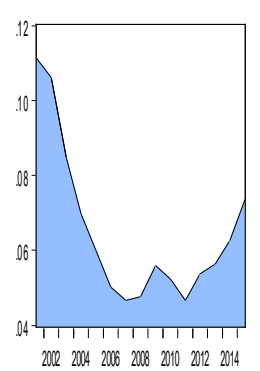

GO

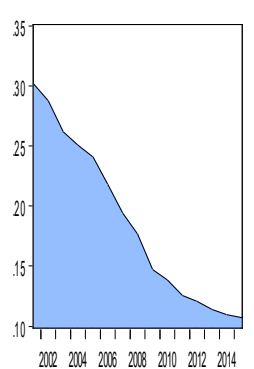

PB

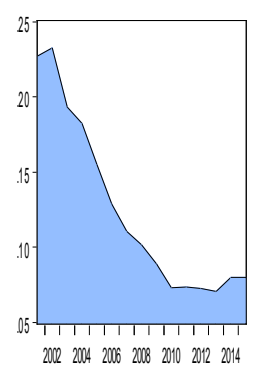

RO

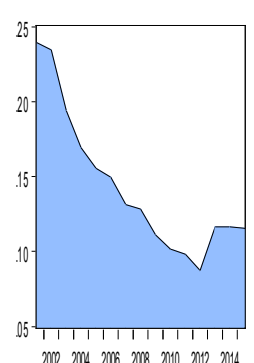

TO

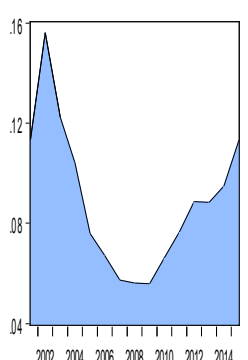

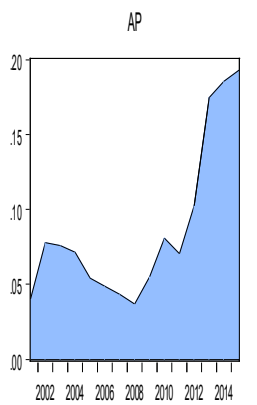

MA

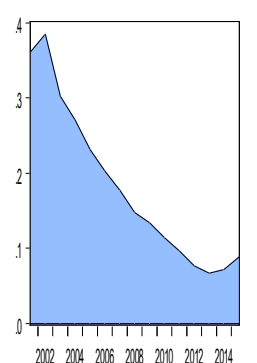

PE

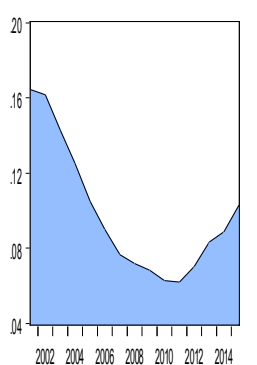

RR

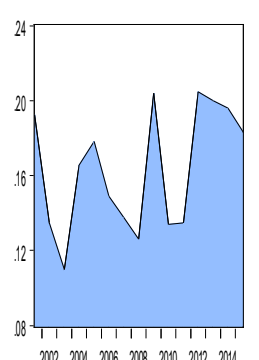

2002200420062008201020122014
BA

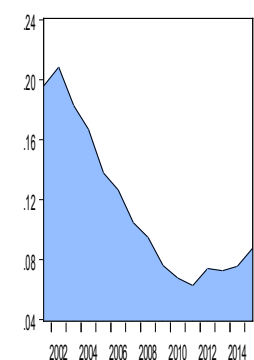

MG

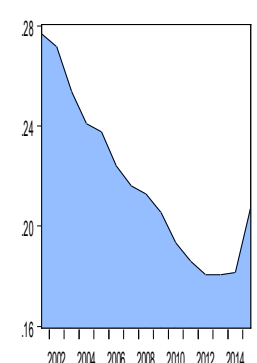

Pl

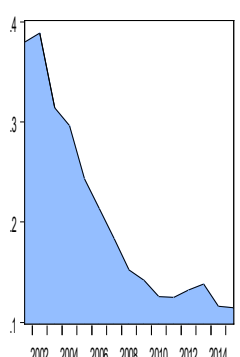

RS

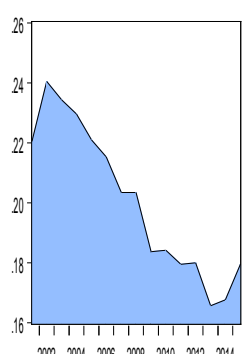

20020042006201020102012014

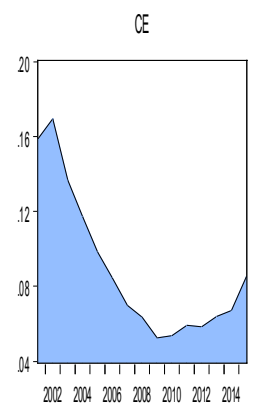

MS

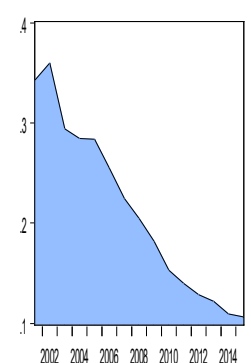

PR

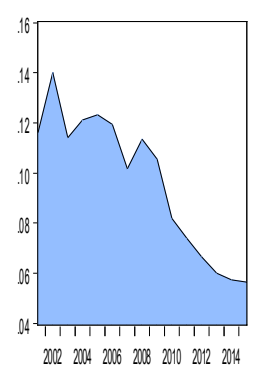

SC

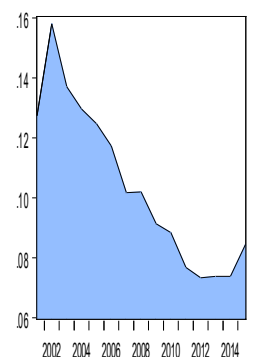

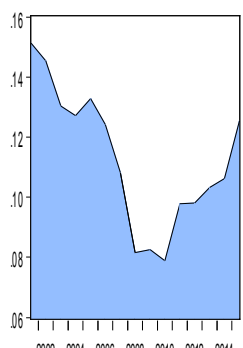

2002200420062008201020122014 
4 - PIB Estadual (2001-2015)

PBEEstado
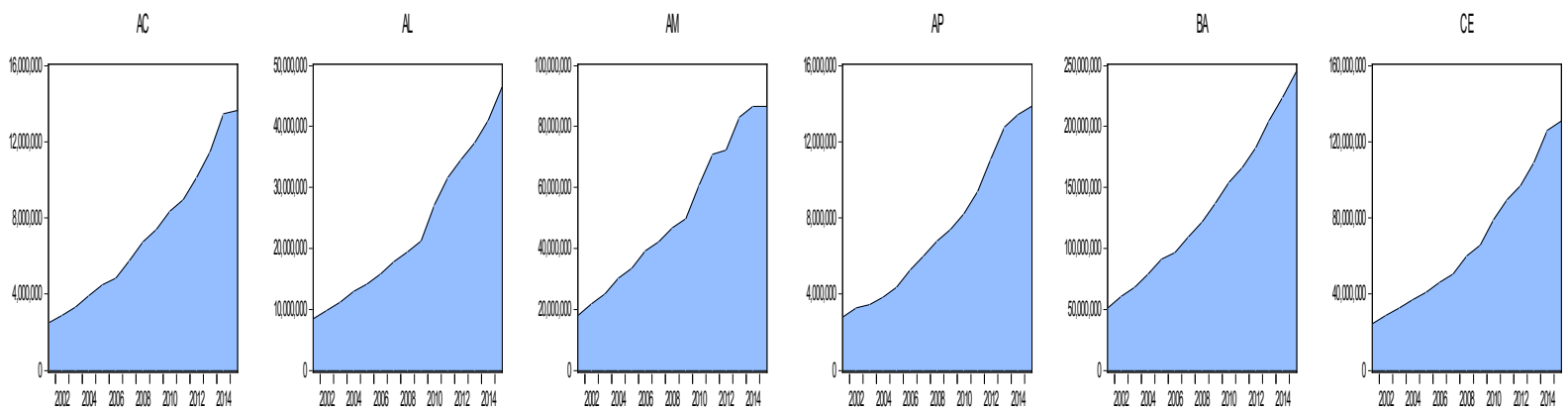

DF

ES

60

MA
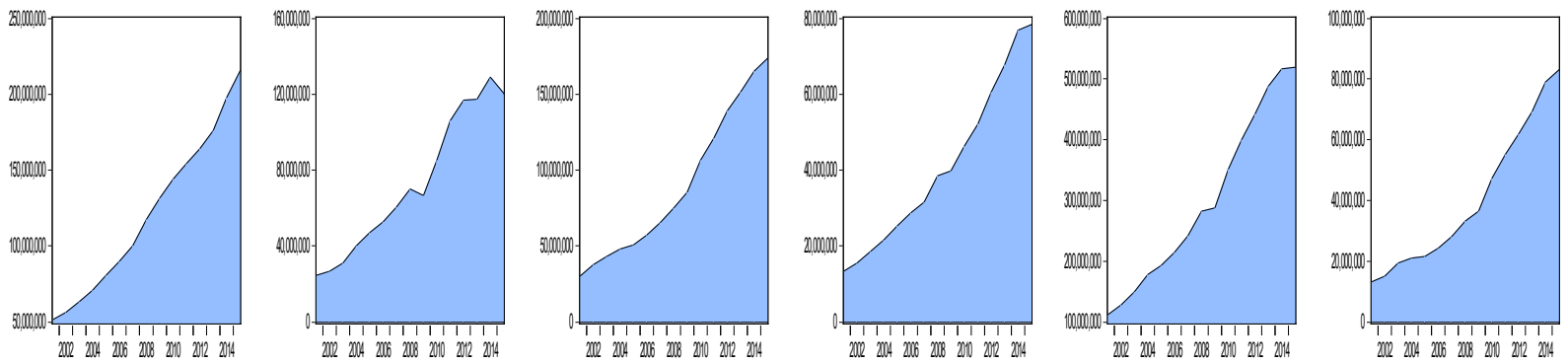

PA

B
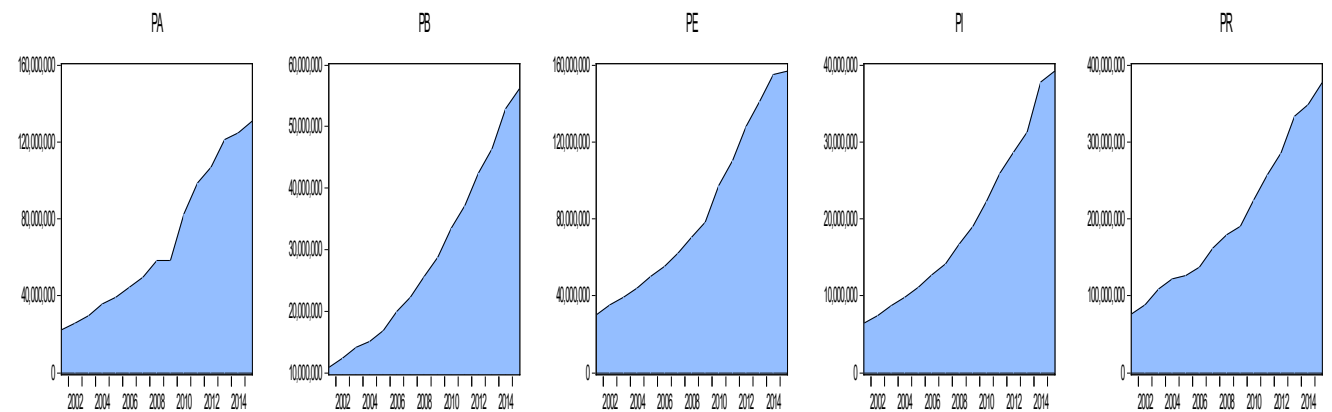

RO

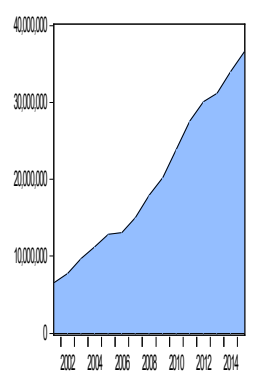

RR

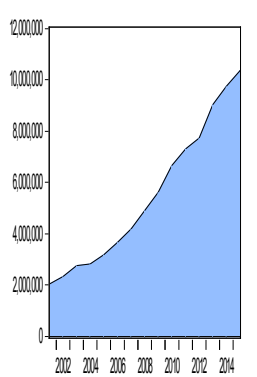

RS
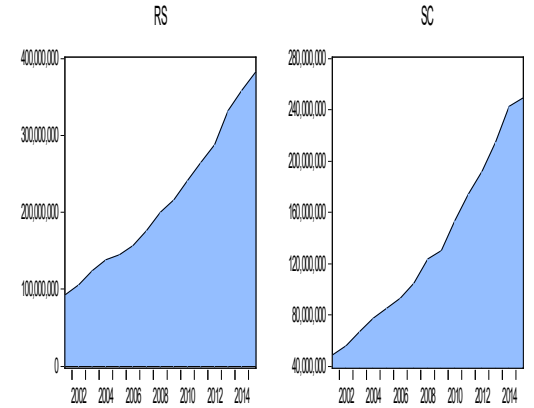

SE

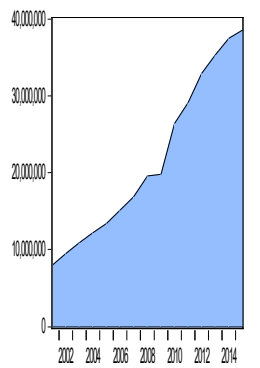

s

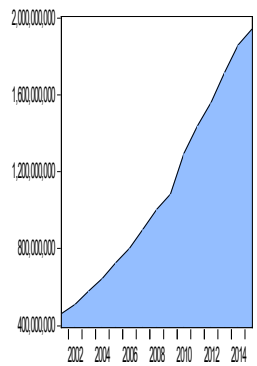

TO

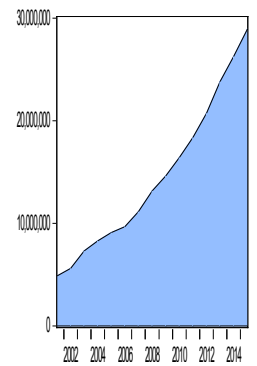


ANEXO B - SAÍDAS DO EVIEWS

Estimação da Função de Reação Fiscal por Dynamic OLS

Modelo 1 - Painel Completo

2001-2015

DC Líquida

\begin{tabular}{lrrrr}
\hline \hline \multicolumn{1}{c}{ Variable } & Coefficient & Std. Error & t-Statistic & Prob. \\
\hline \hline \multicolumn{1}{c}{ DCLPIB(-1) } & 0.056002 & 0.012127 & 4.618044 & 0.0000 \\
YVAR & $-8.99 E-11$ & $1.67 \mathrm{E}-10$ & -0.538124 & 0.5908 \\
\hline \hline R-squared & 0.354842 & Mean dependent var & 0.010292 \\
Adjusted R-squared & 0.307053 & S.D. dependent var & 0.025050 \\
S.E. of regression & 0.020853 & Sum squared resid & 0.152630 \\
Long-run variance & 0.000757 & & \\
\hline \hline
\end{tabular}

DC Bruta

\begin{tabular}{lrlll}
\hline \hline \multicolumn{1}{c}{ Variable } & Coefficient & Std. Error & t-Statistic & Prob. \\
\hline \hline \multicolumn{1}{c}{ DCPIB(-1) } & 0.055285 & 0.011279 & 4.901373 & 0.0000 \\
YVAR & $-8.86 \mathrm{E}-11$ & $1.58 \mathrm{E}-10$ & -0.561448 & 0.5749 \\
\hline \hline R-squared & 0.406086 & Mean dependent var & 0.010292 \\
Adjusted R-squared & 0.362093 & S.D. dependent var & 0.025050 \\
S.E. of regression & 0.020008 & Sum squared resid & 0.140507 \\
Long-run variance & 0.000712 & & \\
\hline \hline
\end{tabular}

2008-2015

DC Líquida

\begin{tabular}{lrlll}
\hline \hline \multicolumn{1}{c}{ Variable } & Coefficient & Std. Error & t-Statistic & Prob. \\
\hline \hline \multicolumn{1}{c}{ DCLPIB(-1) } & 0.014801 & 0.014710 & 1.006169 & 0.3155 \\
YVAR & $-7.80 \mathrm{E}-11$ & $1.13 \mathrm{E}-10$ & -0.687822 & 0.4923 \\
\hline \hline R-squared & 0.227541 & Mean dependent var & 0.004062 \\
Adjusted R-squared & 0.231117 & S.D. dependent var & 0.015964 \\
S.E. of regression & 0.013998 & Sum squared resid & 0.042327 \\
Durbin-Watson stat & 1.530509 & Long-run variance & 0.000277 \\
\hline \hline
\end{tabular}

DC Bruta

\begin{tabular}{lrlll}
\hline \hline \multicolumn{1}{c}{ Variable } & Coefficient & Std. Error & t-Statistic & Prob. \\
\hline \hline \multicolumn{1}{c}{ DCPIB(-1) } & 0.015546 & 0.012103 & 1.284508 & 0.2003 \\
YVAR & $-8.67 \mathrm{E}-11$ & $1.06 \mathrm{E}-10$ & -0.817204 & 0.4147 \\
\hline \hline R-squared & 0.323771 & Mean dependent var & 0.004062 \\
Adjusted R-squared & 0.326901 & S.D. dependent var & 0.015964 \\
S.E. of regression & 0.013098 & Sum squared resid & 0.037054 \\
Durbin-Watson stat & 1.296569 & Long-run variance & 0.000265 \\
\hline \hline
\end{tabular}


2001-2020

DC Líquida

\begin{tabular}{lrrrr}
\hline \hline \multicolumn{1}{c}{ Variable } & Coefficient & Std. Error & t-Statistic & Prob. \\
\hline \hline \multicolumn{1}{c}{ DCLPIB(-1) } & 0.027025 & 0.010515 & 2.570082 & 0.0105 \\
YVAR & $-3.98 \mathrm{E}-19$ & $4.07 \mathrm{E}-19$ & -0.977086 & 0.3291 \\
\hline \hline R-squared & 0.571389 & Mean dependent var & 0.007360 \\
Adjusted R-squared & 0.437310 & S.D. dependent var & 0.022543 \\
S.E. of regression & 0.016910 & Sum squared resid & 0.111519 \\
Long-run variance & 0.000455 & & \\
\hline \hline
\end{tabular}

\begin{tabular}{lrlll}
\hline \hline DC Bruta & & & & \\
\hline \hline \multicolumn{1}{c}{ Variable } & Coefficient & Std. Error & t-Statistic & Prob. \\
\hline \hline DCPIB(-1) & 0.023112 & 0.010493 & 2.202723 & 0.0282 \\
YVAR & $-5.66 \mathrm{E}-19$ & $4.28 \mathrm{E}-19$ & -1.322952 & 0.1866 \\
\hline \hline R-squared & 0.493283 & Mean dependent var & 0.007360 \\
Adjusted R-squared & 0.373336 & S.D. dependent var & 0.022543 \\
S.E. of regression & 0.017845 & Sum squared resid & 0.131841 \\
Long-run variance & 0.000570 & & & \\
\hline \hline
\end{tabular}

\section{8-2020}

DC Líquida

\begin{tabular}{lclll}
\hline \hline \multicolumn{1}{c}{ Variable } & Coefficient & Std. Error & t-Statistic & Prob. \\
\hline \hline \multicolumn{1}{c}{ DCLPIB(-1) } & 0.012567 & 0.008424 & 1.491892 & 0.1366 \\
YVAR & $-8.32 \mathrm{E}-20$ & $2.55 \mathrm{E}-19$ & -0.326543 & 0.7442 \\
\hline \hline R-squared & 0.157693 & Mean dependent var & 0.002172 \\
Adjusted R-squared & 0.160093 & S.D. dependent var & 0.013944 \\
S.E. of regression & 0.012780 & Sum squared resid & 0.057324 \\
Durbin-Watson stat & 1.370316 & Long-run variance & 0.000242 \\
\hline \hline DC Bruta & & & & \\
\hline \hline \multicolumn{1}{c}{ Variable } & Coefficient & Std. Error & t-Statistic & \multirow{2}{*}{ Prob. } \\
\hline \hline \multicolumn{1}{c}{ DCPIB(-1) } & 0.008061 & 0.006913 & 1.166099 & 0.2444 \\
YVAR & $-1.34 \mathrm{E}-19$ & 2.48E-19 & -0.539883 & 0.5896 \\
\hline \hline R-squared & 0.249048 & Mean dependent var & 0.002172 \\
Adjusted R-squared & 0.251188 & S.D. dependent var & 0.013944 \\
S.E. of regression & 0.012067 & Sum squared resid & 0.051107 \\
Durbin-Watson stat & 1.248042 & Long-run variance & 0.000229 \\
\hline \hline
\end{tabular}




\section{Modelo 2 - Separação por Regiões}

\subsection{Norte}

\section{1-2015}

DC Líquida

\begin{tabular}{lrlrr}
\multicolumn{1}{c}{ Variable } & Coefficient & Std. Error & t-Statistic & Prob. \\
\hline \hline \multicolumn{1}{c}{ DCLPIB(-1) } & 0.094713 & 0.057967 & 1.633912 & 0.1057 \\
YVAR & $-1.98 \mathrm{E}-10$ & $2.73 \mathrm{E}-09$ & -0.072737 & 0.9422 \\
\hline \hline R-squared & 0.326638 & Mean dependent var & 0.018099 \\
Adjusted R-squared & 0.282241 & S.D. dependent var & 0.045180 \\
S.E. of regression & 0.038277 & Sum squared resid & 0.133328 \\
Long-run variance & 0.002609 & & \\
\hline \hline
\end{tabular}

DC Bruta

\begin{tabular}{lrlll}
\multicolumn{1}{c}{ Variable } & Coefficient & Std. Error & t-Statistic & Prob. \\
\hline \hline \multicolumn{1}{c}{ DCPIB(-1) } & 0.096855 & 0.041802 & 2.316978 & 0.0227 \\
\multicolumn{1}{c}{ YVAR } & $-6.87 \mathrm{E}-12$ & $2.57 \mathrm{E}-09$ & -0.002667 & 0.9979 \\
\hline \hline R-squared & 0.392805 & Mean dependent var & 0.018099 \\
Adjusted R-squared & 0.352770 & S.D. dependent var & 0.045180 \\
S.E. of regression & 0.036348 & Sum squared resid & 0.120227 \\
Long-run variance & 0.002383 & & \\
\hline \hline
\end{tabular}

\section{8-2015}

DC Líquida

\begin{tabular}{lrlll}
\hline \hline \multicolumn{1}{c}{ Variable } & Coefficient & Std. Error & t-Statistic & Prob. \\
\hline \hline \multicolumn{1}{c}{ DCLPIB(-1) } & -0.024292 & 0.055645 & -0.436563 & 0.6641 \\
YVAR & $1.80 \mathrm{E}-12$ & $1.71 \mathrm{E}-09$ & 0.001048 & 0.9992 \\
\hline \hline R-squared & 0.213338 & Mean dependent var & 0.004665 \\
Adjusted R-squared & 0.227385 & S.D. dependent var & 0.028336 \\
S.E. of regression & 0.024907 & Sum squared resid & 0.034739 \\
Durbin-Watson stat & 1.449045 & Long-run variance & 0.000915 \\
\hline \hline
\end{tabular}

DC Bruta

\begin{tabular}{lrrrr}
\hline \hline \multicolumn{1}{c}{ Variable } & Coefficient & Std. Error & t-Statistic & Prob. \\
\hline \hline \multicolumn{1}{c}{ DCPIB(-1) } & 0.016712 & 0.036256 & 0.460955 & 0.6466 \\
YVAR & $-3.58 \mathrm{E}-11$ & $1.70 \mathrm{E}-09$ & -0.021086 & 0.9833 \\
\hline \hline R-squared & 0.296066 & Mean dependent var & 0.004665 \\
Adjusted R-squared & 0.308636 & S.D. dependent var & 0.028336 \\
S.E. of regression & 0.023561 & Sum squared resid & 0.031086 \\
Durbin-Watson stat & 1.189270 & Long-run variance & 0.000913 \\
\hline \hline
\end{tabular}




\section{1-2020}

DC Líquida

\begin{tabular}{lrrrr}
\multicolumn{1}{c}{ Variable } & Coefficient & Std. Error & t-Statistic & Prob. \\
\hline \hline \multicolumn{1}{c}{ DCLPIB(-1) } & 0.041750 & 0.044112 & 0.946460 & 0.3462 \\
YVAR & $-5.61 \mathrm{E}-19$ & $1.49 \mathrm{E}-18$ & -0.376085 & 0.7076 \\
\hline \hline R-squared & 0.537949 & Mean dependent var & 0.013224 \\
Adjusted R-squared & 0.402051 & S.D. dependent var & 0.040199 \\
S.E. of regression & 0.031085 & Sum squared resid & 0.098560 \\
Long-run variance & 0.001586 & & \\
\hline \hline
\end{tabular}

DC Bruta

\begin{tabular}{lrrrr}
\hline \hline Variable & Coefficient & Std. Error & t-Statistic & Prob. \\
\hline \hline DCPIB(-1) & 0.032803 & 0.034009 & 0.964539 & 0.3369 \\
YVAR & $-2.37 \mathrm{E}-19$ & $1.60 \mathrm{E}-18$ & -0.147705 & 0.8828 \\
\hline \hline R-squared & 0.455063 & Mean dependent var & 0.013224 \\
Adjusted R-squared & 0.351967 & S.D. dependent var & 0.040199 \\
S.E. of regression & 0.032361 & Sum squared resid & 0.116240 \\
Long-run variance & 0.002009 & & & \\
\hline \hline
\end{tabular}

\section{8-2020}

DC Líquida

\begin{tabular}{lrlll}
\hline \hline \multicolumn{1}{c}{ Variable } & Coefficient & Std. Error & t-Statistic & Prob. \\
\hline \hline DCLPIB(-1) & 0.010532 & 0.030214 & 0.348573 & 0.7282 \\
YVAR & $4.83 \mathrm{E}-19$ & $9.14 \mathrm{E}-19$ & 0.528020 & 0.5988 \\
\hline \hline R-squared & 0.133461 & Mean dependent var & 0.002706 \\
Adjusted R-squared & 0.142983 & S.D. dependent var & 0.023845 \\
S.E. of regression & 0.022075 & Sum squared resid & 0.044343 \\
Durbin-Watson stat & 1.327309 & Long-run variance & 0.000743 \\
\hline \hline
\end{tabular}

DC Bruta

\begin{tabular}{lrlll}
\hline \hline \multicolumn{1}{c}{ Variable } & Coefficient & Std. Error & t-Statistic & Prob. \\
\hline \hline \multicolumn{1}{c}{ DCPIB(-1) } & 0.010736 & 0.020227 & 0.530750 & 0.5969 \\
YVAR & $3.57 \mathrm{E}-19$ & $8.90 \mathrm{E}-19$ & 0.401045 & 0.6893 \\
\hline \hline R-squared & 0.235631 & Mean dependent var & 0.002706 \\
Adjusted R-squared & 0.244030 & S.D. dependent var & 0.023845 \\
S.E. of regression & 0.020732 & Sum squared resid & 0.039115 \\
Durbin-Watson stat & 1.198206 & Long-run variance & 0.000696 \\
\hline \hline
\end{tabular}




\subsection{Nordeste}

\section{1-2015}

DC Líquida

\begin{tabular}{lrlll}
\hline \hline Variable & Coefficient & Std. Error & t-Statistic & Prob. \\
\hline \hline DCLPIB(-1) & 0.058066 & 0.006564 & 8.846775 & 0.0000 \\
YVAR & $-9.97 \mathrm{E}-10$ & $4.63 \mathrm{E}-10$ & -2.155702 & 0.0332 \\
\hline \hline R-squared & 0.477545 & Mean dependent var & 0.008887 \\
Adjusted R-squared & 0.441821 & S.D. dependent var & 0.012646 \\
S.E. of regression & 0.009448 & Sum squared resid & 0.010444 \\
Long-run variance & 0.000101 & & \\
\hline \hline
\end{tabular}

DC Bruta

\begin{tabular}{|c|c|c|c|c|}
\hline Variable & Coefficient & Std. Error & $\mathrm{t}$-Statistic & Prob. \\
\hline $\begin{array}{l}\text { DCPIB(-1) } \\
\text { YVAR }\end{array}$ & $\begin{array}{r}0.046616 \\
-8.27 E-10\end{array}$ & $\begin{array}{l}0.006711 \\
4.54 \mathrm{E}-10\end{array}$ & $\begin{array}{r}6.945914 \\
-1.823223\end{array}$ & $\begin{array}{l}0.0000 \\
0.0708\end{array}$ \\
\hline $\begin{array}{l}\text { R-squared } \\
\text { Adjusted R-squared } \\
\text { S.E. of regression } \\
\text { Long-run variance }\end{array}$ & $\begin{array}{l}0.482021 \\
0.446604 \\
0.009407 \\
0.000104\end{array}$ & \multicolumn{2}{|c|}{$\begin{array}{l}\text { Mean dependent var } \\
\text { S.D. dependent var } \\
\text { Sum squared resid }\end{array}$} & $\begin{array}{l}0.008887 \\
0.012646 \\
0.010354\end{array}$ \\
\hline Variable & Coefficient & Std. Error & t-Statistic & Prob. \\
\hline $\begin{array}{c}\text { DCLPIB(-1) } \\
\text { YVAR }\end{array}$ & $\begin{array}{r}0.028748 \\
-6.24 \mathrm{E}-10\end{array}$ & $\begin{array}{l}0.011059 \\
4.41 \mathrm{E}-10\end{array}$ & $\begin{array}{r}2.599409 \\
-1.415712\end{array}$ & $\begin{array}{l}0.0113 \\
0.1612\end{array}$ \\
\hline $\begin{array}{l}\text { R-squared } \\
\text { Adjusted R-squared } \\
\text { S.E. of regression } \\
\text { Durbin-Watson stat }\end{array}$ & $\begin{array}{l}0.316737 \\
0.326226 \\
0.007712 \\
1.894411\end{array}$ & \multicolumn{2}{|c|}{$\begin{array}{l}\text { Mean dependent var } \\
\text { S.D. dependent var } \\
\text { Sum squared resid } \\
\text { Long-run variance }\end{array}$} & $\begin{array}{l}0.003749 \\
0.009396 \\
0.004283 \\
5.83 E-05\end{array}$ \\
\hline
\end{tabular}

DC Bruta

\begin{tabular}{lrlll}
\hline \hline \multicolumn{1}{c}{ Variable } & Coefficient & Std. Error & t-Statistic & Prob. \\
\hline \hline \multicolumn{1}{c}{ DCPIB(-1) } & 0.015423 & 0.009310 & 1.656603 & 0.1020 \\
YVAR & $-2.24 \mathrm{E}-10$ & $4.44 \mathrm{E}-10$ & -0.503937 & 0.6158 \\
\hline \hline R-squared & 0.374406 & Mean dependent var & 0.003749 \\
Adjusted R-squared & 0.383095 & S.D. dependent var & 0.009396 \\
S.E. of regression & 0.007380 & Sum squared resid & 0.003921 \\
Durbin-Watson stat & 1.865156 & Long-run variance & $5.37 \mathrm{E}-05$ \\
\hline \hline
\end{tabular}

\section{1-2020}

DC Líquida

\begin{tabular}{crrrr}
\hline \hline Variable & Coefficient & Std. Error & t-Statistic & Prob. \\
\hline \hline DCLPIB(-1) & 0.035815 & 0.006108 & 5.863530 & 0.0000 \\
YVAR & $-4.64 \mathrm{E}-19$ & $2.91 \mathrm{E}-19$ & -1.590971 & 0.1141 \\
\hline \hline R-squared & 0.729696 & Mean dependent var & 0.006688
\end{tabular}




\begin{tabular}{lclll} 
Adjusted R-squared & 0.643786 & S.D. dependent var & 0.012118 \\
S.E. of regression & 0.007233 & Sum squared resid & 0.006748 \\
Long-run variance & $5.66 \mathrm{E}-05$ & & & \\
\hline \hline DC Bruta & & & & \\
\hline \hline Variable & Coefficient & Std. Error & t-Statistic & Prob. \\
\hline \hline DCPIB(-1) & 0.027791 & 0.006535 & 4.252914 & 0.0000 \\
YVAR & $-7.56 \mathrm{E}-19$ & $2.75 \mathrm{E}-19$ & -2.752770 & 0.0067 \\
\hline \hline R-squared & 0.650059 & Mean dependent var & 0.006688 \\
Adjusted R-squared & 0.586875 & S.D. dependent var & 0.012118 \\
S.E. of regression & 0.007789 & Sum squared resid & 0.008736 \\
Long-run variance & $7.09 \mathrm{E}-05$ & & & \\
\hline \hline
\end{tabular}

2008-2020

DC Líquida

\begin{tabular}{lrlll}
\hline \hline \multicolumn{1}{c}{ Variable } & Coefficient & Std. Error & t-Statistic & Prob. \\
\hline \hline \multicolumn{1}{c}{ DCLPIB(-1) } & 0.027920 & 0.008604 & 3.245148 & 0.0015 \\
YVAR & $-4.51 \mathrm{E}-19$ & $2.65 \mathrm{E}-19$ & -1.704344 & 0.0910 \\
\hline \hline R-squared & 0.278128 & Mean dependent var & 0.002512 \\
Adjusted R-squared & 0.284298 & S.D. dependent var & 0.008913 \\
S.E. of regression & 0.007540 & Sum squared resid & 0.006652 \\
Durbin-Watson stat & 1.546388 & Long-run variance & $7.39 \mathrm{E}-05$ \\
\hline \hline
\end{tabular}

DC Bruta

\begin{tabular}{lrlll}
\hline \hline \multicolumn{1}{c}{ Variable } & Coefficient & Std. Error & t-Statistic & Prob. \\
\hline \hline DCPIB(-1) & 0.014806 & 0.007814 & 1.894879 & 0.0606 \\
YVAR & $-4.18 \mathrm{E}-19$ & $2.66 \mathrm{E}-19$ & -1.575270 & 0.1179 \\
\hline \hline R-squared & 0.302917 & Mean dependent var & 0.002512 \\
Adjusted R-squared & 0.308875 & S.D. dependent var & 0.008913 \\
S.E. of regression & 0.007410 & Sum squared resid & 0.006424 \\
Durbin-Watson stat & 1.516886 & Long-run variance & $7.33 \mathrm{E}-05$ \\
\hline \hline
\end{tabular}

\section{3 - Centro Oeste}

\section{1-2015}

DC Líquida

\begin{tabular}{lrlll}
\hline \hline \multicolumn{1}{c}{ Variable } & Coefficient & Std. Error & t-Statistic & Prob. \\
\hline \hline \multicolumn{1}{c}{ DCLPIB(-1) } & 0.059309 & 0.007591 & 7.812708 & 0.0000 \\
YVAR & $-6.56 \mathrm{E}-10$ & $2.07 \mathrm{E}-10$ & -3.176026 & 0.0025 \\
\hline \hline R-squared & 0.644909 & Mean dependent var & 0.007597 \\
Adjusted R-squared & 0.624423 & S.D. dependent var & 0.008745 \\
S.E. of regression & 0.005359 & Sum squared resid & 0.001493 \\
Long-run variance & $2.97 \mathrm{E}-05$ & & & \\
\hline \hline
\end{tabular}

DC Bruta 


\begin{tabular}{lrlll}
\hline \hline Variable & Coefficient & Std. Error & t-Statistic & Prob. \\
\hline \hline DCPIB(-1) & 0.048999 & 0.006955 & 7.045460 & 0.0000 \\
YVAR & $-7.00 \mathrm{E}-10$ & $1.93 \mathrm{E}-10$ & -3.629083 & 0.0006 \\
\hline \hline R-squared & 0.650406 & Mean dependent var & 0.007597 \\
Adjusted R-squared & 0.630237 & S.D. dependent var & 0.008745 \\
S.E. of regression & 0.005317 & Sum squared resid & 0.001470 \\
Long-run variance & $2.57 \mathrm{E}-05$ & & & \\
\hline \hline
\end{tabular}

2008-2015

DC Líquida

\begin{tabular}{lrlll}
\multicolumn{1}{c}{ Variable } & Coefficient & Std. Error & t-Statistic & Prob. \\
\hline \hline \multicolumn{1}{c}{ DCLPIB(-1) } & 0.098117 & 0.019986 & 4.909235 & 0.0000 \\
YVAR & $-6.38 \mathrm{E}-10$ & $2.39 \mathrm{E}-10$ & -2.675005 & 0.0117 \\
\hline \hline R-squared & 0.644053 & Mean dependent var & 0.004398 \\
Adjusted R-squared & 0.655176 & S.D. dependent var & 0.008246 \\
S.E. of regression & 0.004842 & Sum squared resid & 0.000750 \\
Durbin-Watson stat & 1.878006 & Long-run variance & $2.33 \mathrm{E}-05$ \\
\hline \hline
\end{tabular}

DC Bruta

\begin{tabular}{lrlll}
\hline \hline \multicolumn{1}{c}{ Variable } & Coefficient & Std. Error & t-Statistic & Prob. \\
\hline \hline \multicolumn{1}{c}{ DCPIB(-1) } & 0.041996 & 0.022083 & 1.901756 & 0.0662 \\
YVAR & $-5.46 \mathrm{E}-10$ & $2.66 \mathrm{E}-10$ & -2.055751 & 0.0480 \\
\hline \hline R-squared & 0.577975 & Mean dependent var & 0.004398 \\
Adjusted R-squared & 0.591163 & S.D. dependent var & 0.008246 \\
S.E. of regression & 0.005272 & Sum squared resid & 0.000890 \\
Durbin-Watson stat & 1.893248 & Long-run variance & $2.62 \mathrm{E}-05$ \\
\hline \hline
\end{tabular}

\section{1-2020}

DC Líquida

\begin{tabular}{lrrrr}
\multicolumn{1}{c}{ Variable } & Coefficient & Std. Error & t-Statistic & Prob. \\
\hline \hline \multicolumn{1}{c}{ DCLPIB(-1) } & 0.036489 & 0.010245 & 3.561485 & 0.0007 \\
YVAR & $-4.94 \mathrm{E}-19$ & $1.92 \mathrm{E}-19$ & -2.572151 & 0.0126 \\
\hline \hline R-squared & 0.786976 & Mean dependent var & 0.004907 \\
Adjusted R-squared & 0.733720 & S.D. dependent var & 0.009268 \\
S.E. of regression & 0.004782 & Sum squared resid & 0.001372 \\
Long-run variance & $2.66 \mathrm{E}-05$ & & \\
\hline \hline
\end{tabular}

\section{Bruta}

\begin{tabular}{crrrr}
\hline \hline Variable & Coefficient & Std. Error & t-Statistic & Prob. \\
\hline \hline DCPIB(-1) & 0.020008 & 0.011830 & 1.691266 & 0.0960 \\
YVAR & $-6.75 \mathrm{E}-19$ & $1.94 \mathrm{E}-19$ & -3.478224 & 0.0009 \\
\hline \hline R-squared & 0.768981 & Mean dependent var & 0.004907 \\
Adjusted R-squared & 0.711226 & S.D. dependent var & 0.009268
\end{tabular}




\begin{tabular}{llll} 
S.E. of regression & 0.004980 & Sum squared resid & 0.001488 \\
Long-run variance & $2.66 \mathrm{E}-05$ & & \\
\hline
\end{tabular}

\section{8-2020}

DC Líquida

\begin{tabular}{lrlrr}
\hline \hline \multicolumn{1}{c}{ Variable } & Coefficient & Std. Error & t-Statistic & Prob. \\
\hline \hline \multicolumn{1}{c}{ DCLPIB(-1) } & 0.022196 & 0.014951 & 1.484599 & 0.1437 \\
YVAR & $-3.59 \mathrm{E}-20$ & $2.44 \mathrm{E}-19$ & -0.147150 & 0.8836 \\
\hline \hline R-squared & 0.353639 & Mean dependent var & 0.001697 \\
Adjusted R-squared & 0.366069 & S.D. dependent var & 0.008178 \\
S.E. of regression & 0.006511 & Sum squared resid & 0.002205 \\
Durbin-Watson stat & 1.633054 & Long-run variance & $4.39 \mathrm{E}-05$ \\
\hline \hline
\end{tabular}

DC Bruta

\begin{tabular}{lclll}
\hline \hline Variable & Coefficient & Std. Error & t-Statistic & Prob. \\
\hline \hline DCPIB(-1) & -0.002055 & 0.014171 & -0.144989 & 0.8853 \\
YVAR & $-1.51 \mathrm{E}-19$ & $2.23 \mathrm{E}-19$ & -0.675952 & 0.5021 \\
\hline \hline R-squared & 0.386790 & Mean dependent var & 0.001697 \\
Adjusted R-squared & 0.398583 & S.D. dependent var & 0.008178 \\
S.E. of regression & 0.006342 & Sum squared resid & 0.002092 \\
Durbin-Watson stat & 1.725627 & Long-run variance & $3.85 \mathrm{E}-05$ \\
\hline \hline
\end{tabular}

\subsection{Sudeste}

\section{1-2015}

DC Liquida

\begin{tabular}{lrrrr}
\hline \hline \multicolumn{1}{c}{ Variable } & Coefficient & Std. Error & t-Statistic & Prob. \\
\hline \hline \multicolumn{1}{c}{ DCLPIB(-1) } & 0.038451 & 0.012282 & 3.130585 & 0.0029 \\
$\quad$ YVAR & $-7.03 \mathrm{E}-11$ & $7.67 \mathrm{E}-11$ & -0.917108 & 0.3633 \\
\hline \hline R-squared & 0.150792 & Mean dependent var & 0.007105 \\
Adjusted R-squared & 0.101799 & S.D. dependent var & 0.009015 \\
S.E. of regression & 0.008544 & Sum squared resid & 0.003796 \\
Long-run variance & 0.000134 & & \\
\hline \hline
\end{tabular}

\section{Bruta}

\begin{tabular}{lrlll}
\hline \hline \multicolumn{1}{c}{ Variable } & Coefficient & Std. Error & t-Statistic & Prob. \\
\hline \hline \multicolumn{1}{c}{ DCPIB(-1) } & 0.037260 & 0.014582 & 2.555252 & 0.0136 \\
YVAR & $-6.62 \mathrm{E}-11$ & $7.59 \mathrm{E}-11$ & -0.872690 & 0.3868 \\
\hline \hline R-squared & 0.163896 & Mean dependent var & 0.007105 \\
Adjusted R-squared & 0.115660 & S.D. dependent var & 0.009015 \\
S.E. of regression & 0.008477 & Sum squared resid & 0.003737 \\
Long-run variance & 0.000140 & & \\
\hline \hline
\end{tabular}


2008-2015

DC Líquida

\begin{tabular}{lrlll}
\hline \hline \multicolumn{1}{c}{ Variable } & Coefficient & Std. Error & t-Statistic & Prob. \\
\hline \hline \multicolumn{1}{c}{ DCLPIB(-1) } & 0.013519 & 0.012996 & 1.040298 & 0.3060 \\
YVAR & $-5.27 \mathrm{E}-11$ & $4.95 \mathrm{E}-11$ & -1.065379 & 0.2947 \\
\hline \hline R-squared & 0.360311 & Mean dependent var & 0.003629 \\
Adjusted R-squared & 0.380302 & S.D. dependent var & 0.007617 \\
S.E. of regression & 0.005996 & Sum squared resid & 0.001151 \\
Durbin-Watson stat & 1.476537 & Long-run variance & $4.53 \mathrm{E}-05$ \\
\hline \hline
\end{tabular}

DC Bruta

\begin{tabular}{lrlrr}
\hline \hline \multicolumn{1}{c}{ Variable } & Coefficient & Std. Error & t-Statistic & Prob. \\
\hline \hline \multicolumn{1}{c}{ DCPIB(-1) } & 0.004863 & 0.012238 & 0.397376 & 0.6937 \\
YVAR & $-6.89 \mathrm{E}-11$ & $3.94 \mathrm{E}-11$ & -1.749448 & 0.0898 \\
\hline \hline R-squared & 0.569558 & Mean dependent var & 0.003629 \\
Adjusted R-squared & 0.583010 & S.D. dependent var & 0.007617 \\
S.E. of regression & 0.004919 & Sum squared resid & 0.000774 \\
Durbin-Watson stat & 1.052357 & Long-run variance & $3.22 \mathrm{E}-05$ \\
\hline \hline
\end{tabular}

\section{1-2020}

DC Líquida

\begin{tabular}{lrrrr}
\hline \hline \multicolumn{1}{c}{ Variable } & Coefficient & Std. Error & t-Statistic & Prob. \\
\hline \hline \multicolumn{1}{c}{ DCLPIB(-1) } & 0.006979 & 0.009394 & 0.742867 & 0.4606 \\
YVAR & $-2.49 \mathrm{E}-19$ & $4.35 \mathrm{E}-19$ & -0.571461 & 0.5699 \\
\hline \hline R-squared & 0.544847 & Mean dependent var & 0.004233 \\
Adjusted R-squared & 0.401114 & S.D. dependent var & 0.009692 \\
S.E. of regression & 0.007500 & Sum squared resid & 0.003207 \\
Long-run variance & $8.14 \mathrm{E}-05$ & & \\
\hline \hline
\end{tabular}

DC Bruta

\begin{tabular}{lrlll}
\hline \hline \multicolumn{1}{c}{ Variable } & Coefficient & Std. Error & t-Statistic & Prob. \\
\hline \hline DCPIB & 0.009483 & 0.008836 & 1.073277 & 0.2872 \\
YVAR & $-1.26 \mathrm{E}-19$ & $4.37 \mathrm{E}-19$ & -0.287591 & 0.7746 \\
\hline \hline R-squared & 0.503151 & Mean dependent var & 0.004499 \\
Adjusted R-squared & 0.386701 & S.D. dependent var & 0.009778 \\
S.E. of regression & 0.007657 & Sum squared resid & 0.003753 \\
Long-run variance & 0.000101 & & & \\
\hline \hline
\end{tabular}


DC Líquida

\begin{tabular}{lclll}
\hline \hline \multicolumn{1}{c}{ Variable } & Coefficient & Std. Error & t-Statistic & Prob. \\
\hline \hline \multicolumn{1}{c}{ DCLPIB(-1) } & -0.005118 & 0.009801 & -0.522163 & 0.6038 \\
YVAR & $-3.26 \mathrm{E}-19$ & $3.63 \mathrm{E}-19$ & -0.899771 & 0.3724 \\
\hline \hline R-squared & 0.231367 & Mean dependent var & 0.000769 \\
Adjusted R-squared & 0.246148 & S.D. dependent var & 0.008043 \\
S.E. of regression & 0.006984 & Sum squared resid & 0.002536 \\
Durbin-Watson stat & 0.874580 & Long-run variance & $8.56 \mathrm{E}-05$ \\
\hline \hline
\end{tabular}

\section{Bruta}

\begin{tabular}{lclll}
\hline \hline \multicolumn{1}{c}{ Variable } & Coefficient & Std. Error & t-Statistic & Prob. \\
\hline \hline \multicolumn{1}{c}{ DCPIB(-1) } & -0.004070 & 0.008859 & -0.459451 & 0.6478 \\
YVAR & $-3.75 \mathrm{E}-19$ & $3.68 \mathrm{E}-19$ & -1.018046 & 0.3134 \\
\hline \hline R-squared & 0.292694 & Mean dependent var & 0.000769 \\
Adjusted R-squared & 0.306296 & S.D. dependent var & 0.008043 \\
S.E. of regression & 0.006699 & Sum squared resid & 0.002334 \\
Durbin-Watson stat & 0.673006 & Long-run variance & $8.54 \mathrm{E}-05$ \\
\hline \hline
\end{tabular}

\section{$2.5 \mathrm{Sul}$}

\section{1-2015}

DC Líquida

\begin{tabular}{lrlll}
\hline \hline \multicolumn{1}{c}{ Variable } & Coefficient & Std. Error & t-Statistic & Prob. \\
\hline \hline \multicolumn{1}{c}{ DCLPIB(-1) } & 0.022947 & 0.007851 & 2.922848 & 0.0057 \\
YVAR & $-2.08 \mathrm{E}-10$ & $1.31 \mathrm{E}-10$ & -1.585119 & 0.1210 \\
\hline \hline R-squared & 0.301958 & Mean dependent var & 0.004138 \\
Adjusted R-squared & 0.266161 & S.D. dependent var & 0.005227 \\
S.E. of regression & 0.004477 & Sum squared resid & 0.000782 \\
Long-run variance & $3.76 \mathrm{E}-05$ & & \\
\hline \hline
\end{tabular}

\section{Bruta}

\begin{tabular}{lrlll}
\hline \hline \multicolumn{1}{c}{ Variable } & Coefficient & Std. Error & t-Statistic & Prob. \\
\hline \hline DCPIB(-1) & 0.026135 & 0.007255 & 3.602582 & 0.0009 \\
YVAR & $-1.83 \mathrm{E}-10$ & $1.28 \mathrm{E}-10$ & -1.432142 & 0.1601 \\
\hline \hline R-squared & 0.308235 & Mean dependent var & 0.004138 \\
Adjusted R-squared & 0.272760 & S.D. dependent var & 0.005227 \\
S.E. of regression & 0.004457 & Sum squared resid & 0.000775 \\
Long-run variance & $3.69 \mathrm{E}-05$ & & \\
\hline \hline
\end{tabular}


2008-2015

DC Líquida

\begin{tabular}{|c|c|c|c|c|}
\hline Variable & Coefficient & Std. Error & t-Statistic & Prob. \\
\hline DCLPIB(-1) & 0.018381 & 0.007904 & 2.325605 & 0.0288 \\
\hline YVAR & $-1.79 E-10$ & 8.10E-11 & -2.207906 & 0.0371 \\
\hline R-squared & 0.370684 & \multicolumn{2}{|c|}{ Mean dependent var } & 0.003719 \\
\hline Adjusted R-squared & 0.396906 & \multicolumn{2}{|c|}{ S.D. dependent var } & 0.004277 \\
\hline S.E. of regression & 0.003322 & \multicolumn{2}{|c|}{ Sum squared resid } & 0.000265 \\
\hline Durbin-Watson stat & 1.615617 & \multicolumn{2}{|c|}{ Long-run variance } & 1.07E-05 \\
\hline \multicolumn{5}{|l|}{ DC Bruta } \\
\hline Variable & Coefficient & Std. Error & t-Statistic & Prob. \\
\hline DCPIB $(-1)$ & 0.017289 & 0.006848 & 2.524723 & 0.0186 \\
\hline YVAR & $-2.04 \mathrm{E}-10$ & $7.63 E-11$ & -2.673529 & 0.0133 \\
\hline R-squared & 0.458248 & \multicolumn{2}{|c|}{ Mean dependent var } & 0.003719 \\
\hline Adjusted R-squared & 0.480821 & \multicolumn{2}{|c|}{ S.D. dependent var } & 0.004277 \\
\hline S.E. of regression & 0.003082 & \multicolumn{2}{|c|}{ Sum squared resid } & 0.000228 \\
\hline Durbin-Watson stat & 1.617583 & \multicolumn{2}{|c|}{ Long-run variance } & 9.98E-06 \\
\hline
\end{tabular}

\section{1-2020}

DC Líquida

\begin{tabular}{lrlll}
\hline \hline \multicolumn{1}{c}{ Variable } & Coefficient & Std. Error & t-Statistic & Prob. \\
\hline \multicolumn{1}{c}{ DCLPIB(-1) } & 0.014483 & 0.005339 & 2.712661 & 0.0096 \\
YVAR & $1.36 \mathrm{E}-20$ & $2.74 \mathrm{E}-19$ & 0.049638 & 0.9606 \\
\hline \hline R-squared & 0.633819 & Mean dependent var & 0.003131 \\
Adjusted R-squared & 0.511759 & S.D. dependent var & 0.005271 \\
S.E. of regression & 0.003683 & Sum squared resid & 0.000570 \\
Long-run variance & $1.62 \mathrm{E}-05$ & & & \\
\hline \hline DC Bruta & & & & \\
\hline \hline \multicolumn{1}{c}{ Variable } & Coefficient & Std. Error & t-Statistic & Prob. \\
\hline \hline \multicolumn{1}{c}{ DCPIB(-1) } & 0.008789 & 0.004892 & 1.796665 & 0.0796 \\
$\quad$ YVAR & $-3.45 \mathrm{E}-19$ & $2.31 \mathrm{E}-19$ & -1.496982 & 0.1419 \\
\hline \hline R-squared & 0.635540 & Mean dependent var & 0.003131 \\
Adjusted R-squared & 0.514053 & S.D. dependent var & 0.005271 \\
S.E. of regression & 0.003674 & Sum squared resid & 0.000567 \\
Long-run variance & $1.31 \mathrm{E}-05$ & & \\
\hline \hline
\end{tabular}


2008-2020

DC Líquida

\begin{tabular}{lrllr}
\hline \hline \multicolumn{1}{c}{ Variable } & Coefficient & Std. Error & t-Statistic & Prob. \\
\hline \hline DCLPIB(-1) & 0.011347 & 0.005523 & 2.054404 & 0.0467 \\
YVAR & $-1.41 \mathrm{E}-19$ & $1.98 \mathrm{E}-19$ & -0.713163 & 0.4800 \\
\hline \hline R-squared & 0.275583 & Mean dependent var & 0.002408 \\
Adjusted R-squared & 0.294158 & S.D. dependent var & 0.004594 \\
S.E. of regression & 0.003860 & Sum squared resid & 0.000581 \\
Durbin-Watson stat & 2.047210 & Long-run variance & $1.51 \mathrm{E}-05$ \\
\hline \hline
\end{tabular}

DC Bruta

\begin{tabular}{lrlll}
\hline \hline \multicolumn{1}{c}{ Variable } & Coefficient & Std. Error & t-Statistic & Prob. \\
\hline \hline \multicolumn{1}{c}{ DCPIB(-1) } & 0.011446 & 0.005383 & 2.126385 & 0.0399 \\
YVAR & $-1.03 \mathrm{E}-19$ & $2.08 \mathrm{E}-19$ & -0.496075 & 0.6226 \\
\hline \hline R-squared & 0.290002 & Mean dependent var & 0.002408 \\
Adjusted R-squared & 0.308207 & S.D. dependent var & 0.004594 \\
S.E. of regression & 0.003821 & Sum squared resid & 0.000569 \\
Durbin-Watson stat & 1.790158 & Long-run variance & $1.69 \mathrm{E}-05$ \\
\hline \hline
\end{tabular}

\section{Modelo 3 - Limite Endógeno}

\subsection{Dívida Alta}

\section{1-2015}

DC Líquida

\begin{tabular}{lrlll}
\hline \hline \multicolumn{1}{c}{ Variable } & Coefficient & Std. Error & t-Statistic & Prob. \\
\hline \hline \multicolumn{1}{c}{ DCLPIB(-1) } & 0.038240 & 0.006412 & 5.964102 & 0.0000 \\
YVAR & $-8.08 \mathrm{E}-11$ & $8.45 \mathrm{E}-11$ & -0.955960 & 0.3407 \\
\hline \hline R-squared & 0.385974 & Mean dependent var & 0.007659 \\
Adjusted R-squared & 0.343035 & S.D. dependent var & 0.014577 \\
S.E. of regression & 0.011815 & Sum squared resid & 0.019962 \\
Long-run variance & 0.000173 & & \\
\hline \hline
\end{tabular}

DC Bruta

\begin{tabular}{lrlrr}
\hline \hline \multicolumn{1}{c}{ Variable } & Coefficient & Std. Error & t-Statistic & Prob. \\
\hline \hline \multicolumn{1}{c}{ DCPIB(-1) } & 0.027143 & 0.005908 & 4.593982 & 0.0000 \\
YVAR & $-7.98 \mathrm{E}-11$ & $7.44 \mathrm{E}-11$ & -1.071345 & 0.2858 \\
\hline \hline R-squared & 0.467726 & Mean dependent var & 0.007659 \\
Adjusted R-squared & 0.430504 & S.D. dependent var & 0.014577 \\
S.E. of regression & 0.011000 & Sum squared resid & 0.017304 \\
Long-run variance & 0.000141 & & \\
\hline \hline
\end{tabular}

\section{8-2015}

DC Líquida 


\begin{tabular}{lrlll}
\hline \hline \multicolumn{1}{c}{ Variable } & Coefficient & Std. Error & t-Statistic & Prob. \\
\hline \hline \multicolumn{1}{c}{ DCLPIB(-1) } & 0.001393 & 0.009357 & 0.148887 & 0.8820 \\
YVAR & $-6.49 \mathrm{E}-11$ & $7.01 \mathrm{E}-11$ & -0.926780 & 0.3566 \\
\hline \hline R-squared & 0.461582 & Mean dependent var & 0.002153 \\
Adjusted R-squared & 0.467700 & S.D. dependent var & 0.013199 \\
S.E. of regression & 0.009629 & Sum squared resid & 0.008160 \\
Durbin-Watson stat & 2.239187 & Long-run variance & $9.52 \mathrm{E}-05$ \\
\hline \hline
\end{tabular}

\begin{tabular}{lclll}
\hline \hline DC Bruta & & & & \\
\hline \hline \multicolumn{1}{c}{ Variable } & Coefficient & Std. Error & t-Statistic & Prob. \\
\hline \hline DCPIB(-1) & -0.012255 & 0.007714 & -1.588747 & 0.1157 \\
YVAR & $-7.74 \mathrm{E}-11$ & $5.85 \mathrm{E}-11$ & -1.321983 & 0.1896 \\
\hline \hline R-squared & 0.526788 & Mean dependent var & 0.002153 \\
Adjusted R-squared & 0.532165 & S.D. dependent var & 0.013199 \\
S.E. of regression & 0.009028 & Sum squared resid & 0.007172 \\
Durbin-Watson stat & 2.419456 & Long-run variance & $7.31 \mathrm{E}-05$ \\
\hline \hline
\end{tabular}

\section{1-2020}

DC Líquida

\begin{tabular}{lrlll}
\hline \hline \multicolumn{1}{c}{ Variable } & Coefficient & Std. Error & t-Statistic & Prob. \\
\hline \hline \multicolumn{1}{c}{ DCLPIB(-1) } & 0.014085 & 0.004307 & 3.270448 & 0.0013 \\
YVAR & $-2.88 \mathrm{E}-19$ & $2.40 \mathrm{E}-19$ & -1.201997 & 0.2312 \\
\hline \hline R-squared & 0.783742 & Mean dependent var & 0.005487 \\
Adjusted R-squared & 0.711657 & S.D. dependent var & 0.014034 \\
S.E. of regression & 0.007536 & Sum squared resid & 0.008859 \\
Long-run variance & $6.20 \mathrm{E}-05$ & & & \\
\hline \hline DC Bruta & & & & \\
\hline \hline \multicolumn{1}{c}{ Variable } & Coefficient & Std. Error & t-Statistic & Prob. \\
\hline \hline \multicolumn{1}{c}{ DCPIB(-1) } & 0.003600 & 0.003813 & 0.944052 & 0.3466 \\
YVAR & $-4.98 \mathrm{E}-19$ & $2.18 \mathrm{E}-19$ & -2.287402 & 0.0235 \\
\hline \hline R-squared & 0.776373 & Mean dependent var & 0.005487 \\
Adjusted R-squared & 0.695985 & S.D. dependent var & 0.014034 \\
S.E. of regression & 0.007738 & Sum squared resid & 0.009161 \\
Long-run variance & $4.66 \mathrm{E}-05$ & & \\
\hline \hline
\end{tabular}

2008-2020

DC Líquida

\begin{tabular}{lrlll}
\hline \hline \multicolumn{1}{c}{ Variable } & Coefficient & Std. Error & t-Statistic & Prob. \\
\hline \hline \multicolumn{1}{c}{ DCLPIB(-1) } & 0.009187 & 0.007148 & 1.285271 & 0.2008 \\
YVAR & $-8.33 \mathrm{E}-20$ & $3.00 \mathrm{E}-19$ & -0.277388 & 0.7819 \\
\hline \hline R-squared & 0.179277 & Mean dependent var & 0.001096 \\
Adjusted R-squared & 0.185016 & S.D. dependent var & 0.012191 \\
S.E. of regression & 0.011006 & Sum squared resid & 0.017322 \\
Durbin-Watson stat & 1.620129 & Long-run variance & 0.000146 \\
\hline \hline
\end{tabular}


DC Bruta

\begin{tabular}{lrlll}
\hline \hline Variable & Coefficient & Std. Error & t-Statistic & Prob. \\
\hline \hline DCPIB(-1) & 0.001067 & 0.005497 & 0.194077 & 0.8464 \\
YVAR & $-6.54 \mathrm{E}-20$ & $2.50 \mathrm{E}-19$ & -0.261821 & 0.7938 \\
\hline \hline R-squared & 0.301221 & Mean dependent var & 0.001096 \\
Adjusted R-squared & 0.306108 & S.D. dependent var & 0.012191 \\
S.E. of regression & 0.010155 & Sum squared resid & 0.014748 \\
Durbin-Watson stat & 2.009640 & Long-run variance & 0.000100 \\
\hline \hline
\end{tabular}

\subsection{Dívida Baixa}

\section{1-2015}

DC Líquida

\begin{tabular}{lrlll}
\hline \hline Variable & Coefficient & Std. Error & t-Statistic & Prob. \\
\hline \hline DCLPIB(-1) & 0.134437 & 0.033385 & 4.026825 & 0.0001 \\
YVAR & $-1.63 \mathrm{E}-10$ & $6.00 \mathrm{E}-10$ & -0.271348 & 0.7864 \\
\hline \hline R-squared & 0.380304 & Mean dependent var & 0.012103 \\
Adjusted R-squared & 0.335614 & S.D. dependent var & 0.030117 \\
S.E. of regression & 0.024548 & Sum squared resid & 0.125343 \\
Long-run variance & 0.001051 & & & \\
\hline \hline
\end{tabular}

Dívida Bruta

\begin{tabular}{lrrrr}
\hline \hline \multicolumn{1}{c}{ Variable } & Coefficient & Std. Error & t-Statistic & Prob. \\
\hline \hline \multicolumn{1}{c}{ DCPIB(-1) } & 0.128796 & 0.024581 & 5.239727 & 0.0000 \\
YVAR & $-1.57 \mathrm{E}-10$ & $5.52 \mathrm{E}-10$ & -0.284786 & 0.7761 \\
\hline \hline R-squared & 0.448743 & Mean dependent var & 0.012103 \\
Adjusted R-squared & 0.408989 & S.D. dependent var & 0.030117 \\
S.E. of regression & 0.023153 & Sum squared resid & 0.111500 \\
Long-run variance & 0.000928 & & \\
\hline \hline
\end{tabular}

\section{8-2015}

DC Líquida

\begin{tabular}{lrlll}
\hline \hline \multicolumn{1}{c}{ Variable } & Coefficient & Std. Error & t-Statistic & Prob. \\
\hline \hline \multicolumn{1}{c}{ DCLPIB(-1) } & 0.090963 & 0.044740 & 2.033154 & 0.0441 \\
YVAR & $-9.03 \mathrm{E}-11$ & $4.24 \mathrm{E}-10$ & -0.213201 & 0.8315 \\
\hline \hline R-squared & 0.159471 & Mean dependent var & 0.005374 \\
Adjusted R-squared & 0.166037 & S.D. dependent var & 0.017546 \\
S.E. of regression & 0.016023 & Sum squared resid & 0.032863 \\
Durbin-Watson stat & 1.408254 & Long-run variance & 0.000380 \\
\hline \hline
\end{tabular}


DC Bruta

\begin{tabular}{lrlll}
\hline \hline \multicolumn{1}{c}{ Variable } & Coefficient & Std. Error & t-Statistic & Prob. \\
\hline \hline \multicolumn{1}{c}{ DCPIB(-1) } & 0.073790 & 0.024154 & 3.054989 & 0.0027 \\
YVAR & $-1.24 \mathrm{E}-10$ & $3.90 \mathrm{E}-10$ & -0.318888 & 0.7503 \\
\hline \hline R-squared & 0.311176 & Mean dependent var & 0.005374 \\
Adjusted R-squared & 0.316557 & S.D. dependent var & 0.017546 \\
S.E. of regression & 0.014505 & Sum squared resid & 0.026932 \\
Durbin-Watson stat & 1.138466 & Long-run variance & 0.000339 \\
\hline \hline
\end{tabular}

2001-2020

DC Líquida

\begin{tabular}{|c|c|c|c|c|}
\hline Variable & Coefficient & Std. Error & t-Statistic & Prob. \\
\hline DCLPIB(-1) & 0.086832 & 0.030462 & 2.850534 & 0.0048 \\
\hline YVAR & $-3.43 E-19$ & $6.44 \mathrm{E}-19$ & -0.533525 & 0.5942 \\
\hline R-squared & 0.546239 & \multirow{4}{*}{\multicolumn{2}{|c|}{$\begin{array}{l}\text { Mean dependent var } \\
\text { S.D. dependent var } \\
\text { Sum squared resid }\end{array}$}} & 0.008647 \\
\hline Adjusted R-squared & 0.412438 & & & 0.026822 \\
\hline S.E. of regression & 0.020560 & & & 0.098913 \\
\hline Long-run variance & 0.000685 & & & \\
\hline \multicolumn{5}{|l|}{ DC Bruta } \\
\hline Variable & Coefficient & Std. Error & t-Statistic & Prob. \\
\hline $\mathrm{DCPIB}(-1)$ & 0.061481 & 0.022181 & 2.771748 & 0.0060 \\
\hline YVAR & $-4.45 E-19$ & $6.48 \mathrm{E}-19$ & -0.687216 & 0.4926 \\
\hline R-squared & 0.457104 & \multirow{4}{*}{\multicolumn{2}{|c|}{$\begin{array}{l}\text { Mean dependent var } \\
\text { S.D. dependent var } \\
\text { Sum squared resid }\end{array}$}} & 0.008647 \\
\hline Adjusted R-squared & 0.369742 & & & 0.026822 \\
\hline S.E. of regression & 0.021294 & & & 0.118343 \\
\hline Long-run variance & 0.000894 & & & \\
\hline
\end{tabular}

2008-2020

DC Líquida

\begin{tabular}{lrlll}
\hline \hline \multicolumn{1}{c}{ Variable } & Coefficient & Std. Error & t-Statistic & Prob. \\
\hline \hline DCLPIB(-1) & 0.030376 & 0.023695 & 1.281973 & 0.2013 \\
YVAR & $-4.64 \mathrm{E}-20$ & $3.84 \mathrm{E}-19$ & -0.120837 & 0.9039 \\
\hline \hline R-squared & 0.147317 & Mean dependent var & 0.002911 \\
Adjusted R-squared & 0.151416 & S.D. dependent var & 0.015015 \\
S.E. of regression & 0.013832 & Sum squared resid & 0.039796 \\
Durbin-Watson stat & 1.253054 & Long-run variance & 0.000306 \\
\hline \hline
\end{tabular}

DC Bruta

\begin{tabular}{lrlrl}
\hline \hline Variable & Coefficient & Std. Error & t-Statistic & Prob. \\
\hline \hline DCPIB(-1) & 0.024100 & 0.014529 & 1.658736 & 0.0987 \\
YVAR & $-1.47 \mathrm{E}-19$ & $3.84 \mathrm{E}-19$ & -0.383468 & 0.7018 \\
\hline \hline R-squared & 0.233141 & Mean dependent var & 0.002911 \\
Adjusted R-squared & 0.236828 & S.D. dependent var & 0.015015 \\
S.E. of regression & 0.013117 & Sum squared resid & 0.035790
\end{tabular}




\section{Modelo 4 - Gasto com pessoal (LRF)}

\section{1 - Limite Máximo}

\section{1-2015}

DC Líquida

\begin{tabular}{lcccc}
\hline \hline \multicolumn{1}{c}{ Variable } & Coefficient & Std. Error & t-Statistic & Prob. \\
\hline \hline \multicolumn{1}{c}{ DCLPIB(-1) } & 0.029469 & 0.029924 & 0.984806 & 0.3284 \\
YVAR & $5.80 \mathrm{E}-19$ & $1.25 \mathrm{E}-18$ & 0.462372 & 0.6454 \\
\hline \hline R-squared & 0.587251 & Mean dependent var & 0.009313 \\
Adjusted R-squared & 0.561851 & S.D. dependent var & 0.039612 \\
S.E. of regression & 0.026221 & Sum squared resid & 0.044689 \\
Long-run variance & 0.001049 & & \\
\hline \hline
\end{tabular}

DC Bruta

\begin{tabular}{lrlll}
\hline \hline \multicolumn{1}{c}{ Variable } & Coefficient & Std. Error & t-Statistic & Prob. \\
\hline \hline \multicolumn{1}{c}{ DCPIB(-1) } & 0.024664 & 0.028230 & 0.873688 & 0.3855 \\
YVAR & $2.80 \mathrm{E}-19$ & $1.20 \mathrm{E}-18$ & 0.232617 & 0.8168 \\
\hline \hline R-squared & 0.670303 & Mean dependent var & 0.009313 \\
Adjusted R-squared & 0.650014 & S.D. dependent var & 0.039612 \\
S.E. of regression & 0.023435 & Sum squared resid & 0.035696 \\
Long-run variance & 0.000967 & & & \\
\hline \hline
\end{tabular}

\section{8-2015}

DC Líquida

\begin{tabular}{lcccc}
\hline \hline \multicolumn{1}{c}{ Variable } & Coefficient & Std. Error & t-Statistic & Prob. \\
\hline \hline \multicolumn{1}{c}{ DCLPIB(-1) } & -0.033396 & 0.018803 & -1.776084 & 0.0833 \\
YVAR & $-7.53 \mathrm{E}-19$ & $6.40 \mathrm{E}-19$ & -1.175932 & 0.2466 \\
\hline \hline R-squared & 0.277065 & Mean dependent var & -0.001811 \\
Adjusted R-squared & 0.295138 & S.D. dependent var & 0.016500 \\
S.E. of regression & 0.013853 & Sum squared resid & 0.007676 \\
Durbin-Watson stat & 2.299920 & Long-run variance & 0.000139 \\
\hline \hline
\end{tabular}

DC Bruta

\begin{tabular}{lllll}
\hline \hline Variable & Coefficient & Std. Error & t-Statistic & Prob. \\
\hline \hline DCPIB(-1) & -0.033377 & 0.012101 & -2.758150 & 0.0087 \\
YVAR & $-7.94 \mathrm{E}-19$ & $4.53 \mathrm{E}-19$ & -1.751591 & 0.0875 \\
\hline \hline R-squared & 0.444831 & Mean dependent var & -0.001811 \\
Adjusted R-squared & 0.458710 & S.D. dependent var & 0.016500 \\
S.E. of regression & 0.012140 & Sum squared resid & 0.005895
\end{tabular}




\section{1-2020}

DC Líquida

\begin{tabular}{lcclc}
\hline \hline \multicolumn{1}{c}{ Variable } & Coefficient & Std. Error & t-Statistic & Prob. \\
\hline \hline \multicolumn{1}{c}{ DCLPIB(-1) } & -0.007266 & 0.007631 & -0.952126 & 0.3445 \\
YVAR & $-9.27 \mathrm{E}-19$ & $4.55 \mathrm{E}-19$ & -2.037036 & 0.0457 \\
\hline \hline R-squared & 0.961449 & Mean dependent var & 0.006412 \\
Adjusted R-squared & 0.945095 & S.D. dependent var & 0.034852 \\
S.E. of regression & 0.008167 & Sum squared resid & 0.004402 \\
Long-run variance & $6.81 \mathrm{E}-05$ & & \\
\hline \hline
\end{tabular}

\section{Bruta}

\begin{tabular}{lrlll}
\hline \hline \multicolumn{1}{c}{ Variable } & Coefficient & Std. Error & t-Statistic & Prob. \\
\hline \hline \multicolumn{1}{c}{ DCPIB(-1) } & 0.007829 & 0.020821 & 0.376019 & 0.7080 \\
YVAR & $1.27 \mathrm{E}-18$ & $1.18 \mathrm{E}-18$ & 1.083952 & 0.2820 \\
\hline \hline R-squared & 0.699550 & Mean dependent var & 0.006412 \\
Adjusted R-squared & 0.607745 & S.D. dependent var & 0.034852 \\
S.E. of regression & 0.021828 & Sum squared resid & 0.034306 \\
Long-run variance & 0.000694 & & \\
\hline \hline
\end{tabular}

\section{8-2020}

DC Líquida

\begin{tabular}{lcllr}
\hline \hline \multicolumn{1}{c}{ Variable } & Coefficient & Std. Error & t-Statistic & Prob. \\
\hline \hline \multicolumn{1}{c}{ DCLPIB(-1) } & -0.010918 & 0.013557 & -0.805350 & 0.4236 \\
YVAR & $-3.65 \mathrm{E}-19$ & $6.04 \mathrm{E}-19$ & -0.604277 & 0.5478 \\
\hline \hline R-squared & 0.148521 & Mean dependent var & -0.001772 \\
Adjusted R-squared & 0.161620 & S.D. dependent var & 0.014943 \\
S.E. of regression & 0.013682 & Sum squared resid & 0.012168 \\
Durbin-Watson stat & 1.601871 & Long-run variance & 0.000235 \\
\hline \hline
\end{tabular}

\section{Bruta}

\begin{tabular}{lcllr}
\hline \hline \multicolumn{1}{c}{ Variable } & Coefficient & Std. Error & t-Statistic & Prob. \\
\hline \hline \multicolumn{1}{c}{ DCPIB(-1) } & -0.012160 & 0.009217 & -1.319286 & 0.1917 \\
YVAR & $-4.14 \mathrm{E}-19$ & $4.79 \mathrm{E}-19$ & -0.863781 & 0.3909 \\
\hline \hline R-squared & 0.298938 & Mean dependent var & -0.001772 \\
Adjusted R-squared & 0.309724 & S.D. dependent var & 0.014943 \\
S.E. of regression & 0.012415 & Sum squared resid & 0.010018 \\
Durbin-Watson stat & 2.178451 & Long-run variance & 0.000144 \\
\hline \hline
\end{tabular}




\section{2 - Limite Prudencial}

\section{1-2015}

DC Líquida

\begin{tabular}{lrlll}
\hline \hline Variable & Coefficient & Std. Error & t-Statistic & Prob. \\
\hline \hline DCLPIB(-1) & 0.048101 & 0.005372 & 8.954196 & 0.0000 \\
YVAR & $-2.48 \mathrm{E}-19$ & $2.45 \mathrm{E}-19$ & -1.010572 & 0.3146 \\
\hline \hline R-squared & 0.498813 & Mean dependent var & 0.007755 \\
Adjusted R-squared & 0.465079 & S.D. dependent var & 0.011716 \\
S.E. of regression & 0.008569 & Sum squared resid & 0.007636 \\
Long-run variance & $6.88 \mathrm{E}-05$ & & & \\
\hline \hline
\end{tabular}

DC Bruta

\begin{tabular}{lrlll}
\hline \hline Variable & Coefficient & Std. Error & t-Statistic & Prob. \\
\hline \hline DCPIB(-1) & 0.035747 & 0.005348 & 6.683594 & 0.0000 \\
YVAR & $-2.58 \mathrm{E}-19$ & $2.39 \mathrm{E}-19$ & -1.081289 & 0.2821 \\
\hline \hline R-squared & 0.529567 & Mean dependent var & 0.007755 \\
Adjusted R-squared & 0.497903 & S.D. dependent var & 0.011716 \\
S.E. of regression & 0.008302 & Sum squared resid & 0.007168 \\
Long-run variance & $6.70 \mathrm{E}-05$ & & \\
\hline \hline
\end{tabular}

\section{8-2015}

DC Líquida

\begin{tabular}{lrlll}
\hline \hline \multicolumn{1}{c}{ Variable } & Coefficient & Std. Error & t-Statistic & Prob. \\
\hline \hline \multicolumn{1}{c}{ DCLPIB(-1) } & 0.032133 & 0.009254 & 3.472466 & 0.0009 \\
YVAR & $-1.59 \mathrm{E}-19$ & $2.57 \mathrm{E}-19$ & -0.618054 & 0.5387 \\
\hline \hline R-squared & 0.457959 & Mean dependent var & 0.003282 \\
Adjusted R-squared & 0.466428 & S.D. dependent var & 0.009569 \\
S.E. of regression & 0.006990 & Sum squared resid & 0.003127 \\
Durbin-Watson stat & 1.909165 & Long-run variance & $4.60 \mathrm{E}-05$ \\
\hline \hline
\end{tabular}

DC Bruta

\begin{tabular}{lrlll}
\hline \hline \multicolumn{1}{c}{ Variable } & Coefficient & Std. Error & t-Statistic & Prob. \\
\hline \hline \multicolumn{1}{c}{ DCPIB(-1) } & 0.014135 & 0.007625 & 1.853769 & 0.0684 \\
YVAR & $-9.60 \mathrm{E}-20$ & $2.31 \mathrm{E}-19$ & -0.415327 & 0.6793 \\
\hline \hline R-squared & 0.538299 & Mean dependent var & 0.003282 \\
Adjusted R-squared & 0.545513 & S.D. dependent var & 0.009569 \\
S.E. of regression & 0.006451 & Sum squared resid & 0.002664 \\
Durbin-Watson stat & 1.975307 & Long-run variance & $3.83 \mathrm{E}-05$ \\
\hline \hline
\end{tabular}

\section{1-2020}

DC Líquida 


\begin{tabular}{lrrrr}
\multicolumn{1}{c}{ Variable } & Coefficient & Std. Error & t-Statistic & Prob. \\
\hline \hline \multicolumn{1}{c}{ DCLPIB(-1) } & 0.034900 & 0.004923 & 7.089700 & 0.0000 \\
YVAR & $-6.84 \mathrm{E}-19$ & $2.24 \mathrm{E}-19$ & -3.052439 & 0.0028 \\
\hline \hline R-squared & 0.759195 & Mean dependent var & 0.005601 \\
Adjusted R-squared & 0.681039 & S.D. dependent var & 0.011449 \\
S.E. of regression & 0.006466 & Sum squared resid & 0.004767 \\
Long-run variance & $3.67 \mathrm{E}-05$ & & \\
\hline \hline
\end{tabular}

DC Bruta

\begin{tabular}{lrlll}
\hline \hline Variable & Coefficient & Std. Error & t-Statistic & Prob. \\
\hline \hline DCPIB(-1) & 0.022250 & 0.005322 & 4.180906 & 0.0001 \\
YVAR & $-8.99 \mathrm{E}-19$ & $2.12 \mathrm{E}-19$ & -4.235984 & 0.0000 \\
\hline \hline R-squared & 0.699737 & Mean dependent var & 0.005601 \\
Adjusted R-squared & 0.640161 & S.D. dependent var & 0.011449 \\
S.E. of regression & 0.006868 & Sum squared resid & 0.005944 \\
Long-run variance & $4.18 \mathrm{E}-05$ & & \\
\hline \hline
\end{tabular}

2008-2020

DC Líquida

\begin{tabular}{lrlll}
\hline \hline \multicolumn{1}{c}{ Variable } & Coefficient & Std. Error & t-Statistic & Prob. \\
\hline \hline \multicolumn{1}{c}{ DCLPIB(-1) } & 0.023041 & 0.007910 & 2.913055 & 0.0044 \\
YVAR & $-2.81 \mathrm{E}-19$ & $2.35 \mathrm{E}-19$ & -1.197678 & 0.2338 \\
\hline \hline R-squared & 0.333508 & Mean dependent var & 0.001855 \\
Adjusted R-squared & 0.339917 & S.D. dependent var & 0.009186 \\
S.E. of regression & 0.007464 & Sum squared resid & 0.005793 \\
Durbin-Watson stat & 1.705950 & Long-run variance & $5.92 \mathrm{E}-05$ \\
\hline \hline
\end{tabular}

DC Bruta

\begin{tabular}{lrlll}
\hline \hline \multicolumn{1}{c}{ Variable } & Coefficient & Std. Error & t-Statistic & Prob. \\
\hline \hline \multicolumn{1}{c}{ DCPIB(-1) } & 0.008837 & 0.007086 & 1.247120 & 0.2152 \\
YVAR & $-3.21 \mathrm{E}-19$ & $2.25 \mathrm{E}-19$ & -1.425167 & 0.1571 \\
\hline \hline R-squared & 0.362985 & Mean dependent var & 0.001855 \\
Adjusted R-squared & 0.369110 & S.D. dependent var & 0.009186 \\
S.E. of regression & 0.007297 & Sum squared resid & 0.005537 \\
Durbin-Watson stat & 1.708349 & Long-run variance & $5.66 \mathrm{E}-05$ \\
\hline \hline
\end{tabular}

\section{3 - Limite de Alerta}

\section{1-2015}

DC Líquida

\begin{tabular}{lrlll}
\hline \hline \multicolumn{1}{c}{ Variable } & Coefficient & Std. Error & t-Statistic & Prob. \\
\hline \hline DCLPIB(-1) & 0.053587 & 0.038627 & 1.387296 & 0.1701 \\
YVAR & $1.10 \mathrm{E}-19$ & $9.90 \mathrm{E}-19$ & 0.111207 & 0.9118 \\
\hline \hline R-squared & 0.226953 & Mean dependent var & 0.009202 \\
Adjusted R-squared & 0.179380 & S.D. dependent var & 0.028896 \\
S.E. of regression & 0.026177 & Sum squared resid & 0.044540
\end{tabular}


Long-run variance $\quad 0.000935$

DC Bruta

\begin{tabular}{lrlll}
\hline \hline Variable & Coefficient & Std. Error & t-Statistic & Prob. \\
\hline \hline DCPIB(-1) & 0.085979 & 0.028641 & 3.001930 & 0.0038 \\
YVAR & $1.93 \mathrm{E}-19$ & $8.66 \mathrm{E}-19$ & 0.223468 & 0.8239 \\
\hline \hline R-squared & 0.158502 & Mean dependent var & 0.009202 \\
Adjusted R-squared & 0.106718 & S.D. dependent var & 0.028896 \\
S.E. of regression & 0.027311 & Sum squared resid & 0.048483 \\
Long-run variance & 0.000785 & & \\
\hline \hline
\end{tabular}

2008-2015

DC Líquida

\begin{tabular}{lcccc}
\hline \hline \multicolumn{1}{c}{ Variable } & Coefficient & Std. Error & t-Statistic & Prob. \\
\hline \hline \multicolumn{1}{c}{ DCLPIB(-1) } & 0.035878 & 0.036666 & 0.978500 & 0.3337 \\
YVAR & $1.08 \mathrm{E}-18$ & $6.98 \mathrm{E}-19$ & 1.543226 & 0.1307 \\
\hline \hline R-squared & 0.313928 & Mean dependent var & 0.005282 \\
Adjusted R-squared & 0.331080 & S.D. dependent var & 0.020660 \\
S.E. of regression & 0.016897 & Sum squared resid & 0.011421 \\
Durbin-Watson stat & 2.290992 & Long-run variance & 0.000262 \\
\hline \hline
\end{tabular}

DC Bruta

\begin{tabular}{lclll}
\hline \hline \multicolumn{1}{c}{ Variable } & Coefficient & Std. Error & t-Statistic & Prob. \\
\hline \hline \multicolumn{1}{c}{ DCPIB(-1) } & 0.074754 & 0.020637 & 3.622322 & 0.0008 \\
YVAR & $4.26 \mathrm{E}-19$ & $5.23 \mathrm{E}-19$ & 0.814082 & 0.4204 \\
\hline \hline R-squared & 0.628528 & Mean dependent var & 0.005282 \\
Adjusted R-squared & 0.637814 & S.D. dependent var & 0.020660 \\
S.E. of regression & 0.012434 & Sum squared resid & 0.006184 \\
Durbin-Watson stat & 1.775451 & Long-run variance & 0.000171 \\
\hline \hline
\end{tabular}

2001-2020

DC Líquida

\begin{tabular}{lrrrr}
\hline \hline \multicolumn{1}{c}{ Variable } & Coefficient & Std. Error & t-Statistic & Prob. \\
\hline \hline \multicolumn{1}{c}{ DCLPIB(-1) } & 0.045065 & 0.031873 & 1.413920 & 0.1614 \\
YVAR & $1.39 \mathrm{E}-19$ & $1.01 \mathrm{E}-18$ & 0.137616 & 0.8909 \\
\hline \hline R-squared & 0.225862 & Mean dependent var & 0.007005 \\
Adjusted R-squared & 0.067065 & S.D. dependent var & 0.025300 \\
S.E. of regression & 0.024437 & Sum squared resid & 0.046579 \\
Long-run variance & 0.000727 & & \\
\hline \hline
\end{tabular}

DC Bruta

\begin{tabular}{crrrr}
\hline \hline Variable & Coefficient & Std. Error & t-Statistic & Prob. \\
\hline \hline DCPIB(-1) & 0.029140 & 0.024904 & 1.170097 & 0.2460 \\
YVAR & $-1.41 \mathrm{E}-18$ & $9.99 \mathrm{E}-19$ & -1.414050 & 0.1618 \\
\hline \hline
\end{tabular}


R-squared

Adjusted R-squared

0.581649 Mean dependent var

0.007005

S.E. of regression

0.430073

S.D. dependent var

0.025300

Long-run variance

0.019100

Sum squared resid

0.025172

\section{8-2020}

DC Líquida

\begin{tabular}{lcccc}
\hline \hline \multicolumn{1}{c}{ Variable } & Coefficient & Std. Error & t-Statistic & Prob. \\
\hline \hline \multicolumn{1}{c}{ DCLPIB(-1) } & 0.030477 & 0.020228 & 1.506698 & 0.1367 \\
YVAR & $9.17 \mathrm{E}-19$ & $5.30 \mathrm{E}-19$ & 1.729698 & 0.0884 \\
\hline \hline R-squared & 0.265372 & Mean dependent var & 0.003579 \\
Adjusted R-squared & 0.276674 & S.D. dependent var & 0.016872 \\
S.E. of regression & 0.014349 & Sum squared resid & 0.013383 \\
Durbin-Watson stat & 1.971885 & Long-run variance & 0.000234 \\
\hline \hline
\end{tabular}

DC Bruta

\begin{tabular}{lclll}
\hline \hline Variable & Coefficient & Std. Error & t-Statistic & Prob. \\
\hline \hline DCPIB(-1) & 0.047338 & 0.013849 & 3.418107 & 0.0011 \\
YVAR & $6.66 \mathrm{E}-19$ & $4.59 \mathrm{E}-19$ & 1.450374 & 0.1518 \\
\hline \hline R-squared & 0.562419 & Mean dependent var & 0.003579 \\
Adjusted R-squared & 0.569151 & S.D. dependent var & 0.016872 \\
S.E. of regression & 0.011074 & Sum squared resid & 0.007972 \\
Durbin-Watson stat & 1.354499 & Long-run variance & 0.000182 \\
\hline \hline
\end{tabular}

\section{4 - Demais Estados}

\section{1-2015}

DC Líquido

\begin{tabular}{lrlll}
\hline \hline \multicolumn{1}{c}{ Variable } & Coefficient & Std. Error & t-Statistic & Prob. \\
\hline \hline DCLPIB(-1) & 0.115358 & 0.032177 & 3.585109 & 0.0005 \\
YVAR & $-9.84 \mathrm{E}-19$ & $9.38 \mathrm{E}-19$ & -1.049278 & 0.2962 \\
\hline \hline R-squared & 0.019686 & Mean dependent var & 0.013698 \\
Adjusted R-squared & -0.047344 & S.D. dependent var & 0.020615 \\
S.E. of regression & 0.021097 & Sum squared resid & 0.052076 \\
Long-run variance & 0.001072 & & \\
\hline \hline
\end{tabular}

DC Bruta

\begin{tabular}{lrlll}
\hline \hline \multicolumn{1}{c}{ Variable } & Coefficient & Std. Error & t-Statistic & Prob. \\
\hline \hline \multicolumn{1}{c}{ DCPIB(-1) } & 0.102243 & 0.030276 & 3.377084 & 0.0010 \\
YVAR & $-9.55 \mathrm{E}-19$ & $9.07 \mathrm{E}-19$ & -1.052134 & 0.2949 \\
\hline \hline R-squared & 0.017378 & Mean dependent var & 0.013698 \\
Adjusted R-squared & -0.049810 & S.D. dependent var & 0.020615 \\
S.E. of regression & 0.021122 & Sum squared resid & 0.052199 \\
Long-run variance & 0.001069 & & \\
\hline \hline
\end{tabular}


2008-2015

DC Líquida

\begin{tabular}{lrlll}
\hline \hline \multicolumn{1}{c}{ Variable } & Coefficient & Std. Error & t-Statistic & Prob. \\
\hline \hline \multicolumn{1}{c}{ DCLPIB(-1) } & 0.070501 & 0.047188 & 1.494037 & 0.1395 \\
YVAR & $-6.71 \mathrm{E}-19$ & $7.87 \mathrm{E}-19$ & -0.852247 & 0.3969 \\
\hline \hline R-squared & 0.018210 & Mean dependent var & 0.007340 \\
Adjusted R-squared & 0.031846 & S.D. dependent var & 0.016577 \\
S.E. of regression & 0.016311 & Sum squared resid & 0.019154 \\
Durbin-Watson stat & 0.815100 & Long-run variance & 0.000486 \\
\hline \hline
\end{tabular}

DC Bruta

\begin{tabular}{lrlll}
\hline \hline \multicolumn{1}{c}{ Variable } & Coefficient & Std. Error & t-Statistic & Prob. \\
\hline \hline \multicolumn{1}{c}{ DCPIB(-1) } & 0.054001 & 0.038623 & 1.398146 & 0.1664 \\
YVAR & $-5.72 \mathrm{E}-19$ & $7.99 \mathrm{E}-19$ & -0.715976 & 0.4763 \\
\hline \hline R-squared & 0.024962 & Mean dependent var & 0.007340 \\
Adjusted R-squared & 0.038504 & S.D. dependent var & 0.016577 \\
S.E. of regression & 0.016254 & Sum squared resid & 0.019023 \\
Durbin-Watson stat & 0.897434 & Long-run variance & 0.000471 \\
\hline \hline
\end{tabular}

\section{1-2020}

DC Líquida

\begin{tabular}{lrrrr}
\hline \hline \multicolumn{1}{c}{ Variable } & Coefficient & Std. Error & t-Statistic & Prob. \\
\hline \hline \multicolumn{1}{c}{ DCLPIB(-1) } & 0.057714 & 0.036109 & 1.598347 & 0.1124 \\
YVAR & $-3.15 \mathrm{E}-19$ & $9.32 \mathrm{E}-19$ & -0.337482 & 0.7363 \\
\hline \hline R-squared & 0.183645 & Mean dependent var & 0.009646 \\
Adjusted R-squared & -0.051366 & S.D. dependent var & 0.019491 \\
S.E. of regression & 0.019985 & Sum squared resid & 0.052722 \\
Long-run variance & 0.000841 & & \\
\hline \hline
\end{tabular}

DC Bruta

\begin{tabular}{lrlll}
\hline \hline \multicolumn{1}{c}{ Variable } & Coefficient & Std. Error & t-Statistic & Prob. \\
\hline \hline \multicolumn{1}{c}{ DCPIB(-1) } & 0.041984 & 0.028287 & 1.484181 & 0.1399 \\
YVAR & $-6.65 \mathrm{E}-19$ & $9.05 \mathrm{E}-19$ & -0.734350 & 0.4639 \\
\hline \hline R-squared & 0.029906 & Mean dependent var & 0.009646 \\
Adjusted R-squared & -0.121877 & S.D. dependent var & 0.019491 \\
S.E. of regression & 0.020645 & Sum squared resid & 0.062651 \\
Long-run variance & 0.000953 & & & \\
\hline \hline
\end{tabular}

\section{8-2020}

DC Líquida

\begin{tabular}{crrrr}
\hline \hline Variable & Coefficient & Std. Error & t-Statistic & Prob. \\
\hline \hline DCLPIB(-1) & 0.027046 & 0.025322 & 1.068094 & 0.2877 \\
YVAR & $-4.65 \mathrm{E}-19$ & $5.72 \mathrm{E}-19$ & -0.812985 & 0.4179
\end{tabular}




\begin{tabular}{llll}
\hline \hline R-squared & 0.062030 & Mean dependent var & 0.003863 \\
Adjusted R-squared & 0.070047 & S.D. dependent var & 0.014789 \\
S.E. of regression & 0.014262 & Sum squared resid & 0.023798 \\
Durbin-Watson stat & 0.823594 & Long-run variance & 0.000374 \\
\hline
\end{tabular}

\begin{tabular}{lcccc}
\hline \hline DC Bruta & & & & \\
\hline \hline \multicolumn{1}{c}{ Variable } & Coefficient & Std. Error & t-Statistic & Prob. \\
\hline \hline \multicolumn{1}{c}{ DCPIB(-1) } & 0.002372 & 0.019776 & 0.119971 & 0.9047 \\
YVAR & $-4.88 \mathrm{E}-19$ & $5.91 \mathrm{E}-19$ & -0.825693 & 0.4107 \\
\hline \hline R-squared & 0.023386 & Mean dependent var & 0.003863 \\
Adjusted R-squared & 0.031733 & S.D. dependent var & 0.014789 \\
S.E. of regression & 0.014553 & Sum squared resid & 0.024778 \\
Durbin-Watson stat & 0.838292 & Long-run variance & 0.000385 \\
\hline \hline
\end{tabular}

\section{Modelo 5 - Relação DCL/RCL (LRF)}

\section{1 - Superior a 2}

\section{1-2015}

DC Líquida

\begin{tabular}{lrlll}
\hline \hline Variable & Coefficient & Std. Error & t-Statistic & Prob. \\
\hline \hline DCLPIB(-1) & 0.019254 & 0.004153 & 4.636729 & 0.0000 \\
YVAR & $-2.25 \mathrm{E}-10$ & $4.85 \mathrm{E}-11$ & -4.641881 & 0.0000 \\
\hline \hline R-squared & 0.555063 & Mean dependent var & 0.003573 \\
Adjusted R-squared & 0.532245 & S.D. dependent var & 0.005655 \\
S.E. of regression & 0.003868 & Sum squared resid & 0.000583 \\
Long-run variance & $1.93 \mathrm{E}-05$ & & & \\
\hline \hline
\end{tabular}

\section{Bruta}

\begin{tabular}{lrlll}
\hline \hline Variable & Coefficient & Std. Error & t-Statistic & Prob. \\
\hline \hline DCPIB(-1) & 0.013116 & 0.004603 & 2.849500 & 0.0070 \\
YVAR & $-1.98 \mathrm{E}-10$ & $4.57 \mathrm{E}-11$ & -4.339158 & 0.0001 \\
\hline \hline R-squared & 0.589735 & Mean dependent var & 0.003573 \\
Adjusted R-squared & 0.568696 & S.D. dependent var & 0.005655 \\
S.E. of regression & 0.003714 & Sum squared resid & 0.000538 \\
Long-run variance & $1.65 \mathrm{E}-05$ & & & \\
\hline \hline
\end{tabular}

\section{8-2015}

DC Líquida

\begin{tabular}{lrlrr}
\hline \hline \multicolumn{1}{c}{ Variable } & Coefficient & Std. Error & t-Statistic & Prob. \\
\hline \hline \multicolumn{1}{c}{ DCLPIB(-1) } & 0.004098 & 0.007125 & 0.575108 & 0.5723 \\
YVAR & $-1.62 \mathrm{E}-10$ & $5.71 \mathrm{E}-11$ & -2.839102 & 0.0109 \\
\hline \hline R-squared & 0.619646 & Mean dependent var & 0.001195 \\
Adjusted R-squared & 0.577385 & S.D. dependent var & 0.005498 \\
S.E. of regression & 0.003574 & Sum squared resid & 0.000230
\end{tabular}


DC Bruta

\begin{tabular}{lclll}
\hline \hline Variable & Coefficient & Std. Error & t-Statistic & Prob. \\
\hline \hline DCPIB(-1) & -0.005340 & 0.007605 & -0.702143 & 0.4916 \\
YVAR & $-1.40 \mathrm{E}-10$ & $5.11 \mathrm{E}-11$ & -2.735532 & 0.0136 \\
\hline \hline R-squared & 0.683831 & Mean dependent var & 0.001195 \\
Adjusted R-squared & 0.648702 & S.D. dependent var & 0.005498 \\
S.E. of regression & 0.003259 & Sum squared resid & 0.000191 \\
Long-run variance & $1.11 \mathrm{E}-05$ & & & \\
\hline \hline
\end{tabular}

2001-2020

DC Líquida

\begin{tabular}{lclll}
\hline \hline \multicolumn{1}{c}{ Variable } & Coefficient & Std. Error & t-Statistic & Prob. \\
\hline \hline DCLPIB(-1) & 0.001014 & 0.006570 & 0.154309 & 0.8781 \\
YVAR & $-4.12 \mathrm{E}-19$ & $4.62 \mathrm{E}-19$ & -0.892735 & 0.3771 \\
\hline \hline R-squared & 0.512423 & Mean dependent var & 0.001266 \\
Adjusted R-squared & 0.349898 & S.D. dependent var & 0.007058 \\
S.E. of regression & 0.005691 & Sum squared resid & 0.001360 \\
Long-run variance & $4.99 \mathrm{E}-05$ & & & \\
\hline \hline DC Bruta & & & & \\
\hline \hline \multicolumn{1}{c}{ Variable } & Coefficient & Std. Error & t-Statistic & Prob. \\
\hline \hline \multicolumn{1}{c}{ DCPIB(-1) } & -0.002012 & 0.003670 & -0.548054 & 0.5868 \\
YVAR & $-6.38 E-19$ & 2.76E-19 & -2.314406 & 0.0260 \\
\hline \hline R-squared & 0.833261 & Mean dependent var & 0.001266 \\
Adjusted R-squared & 0.760580 & S.D. dependent var & 0.007058 \\
S.E. of regression & 0.003454 & Sum squared resid & 0.000465 \\
Long-run variance & $1.43 E-05$ & & & \\
\hline \hline
\end{tabular}

\section{8-2020}

DC Líquida

\begin{tabular}{lclll}
\hline \hline \multicolumn{1}{c}{ Variable } & Coefficient & Std. Error & t-Statistic & Prob. \\
\hline \hline \multicolumn{1}{c}{ DCLPIB(-1) } & -0.005366 & 0.008438 & -0.635961 & 0.5285 \\
YVAR & $-3.53 \mathrm{E}-19$ & $4.14 \mathrm{E}-19$ & -0.852164 & 0.3993 \\
\hline \hline R-squared & 0.205168 & Mean dependent var & -0.000804 \\
Adjusted R-squared & 0.225549 & S.D. dependent var & 0.007106 \\
S.E. of regression & 0.006254 & Sum squared resid & 0.001525 \\
Durbin-Watson stat & 0.684779 & Long-run variance & $8.03 \mathrm{E}-05$ \\
\hline \hline
\end{tabular}

\section{Bruta}

\begin{tabular}{ccccc}
\hline \hline Variable & Coefficient & Std. Error & t-Statistic & Prob. \\
\hline \hline DCPIB(-1) & -0.005966 & 0.008021 & -0.743866 & 0.4614 \\
YVAR & $-3.33 \mathrm{E}-19$ & $4.15 \mathrm{E}-19$ & -0.801915 & 0.4275 \\
\hline \hline R-squared & 0.220826 & Mean dependent var & -0.000804 \\
Adjusted R-squared & 0.240805 & S.D. dependent var & 0.007106
\end{tabular}


S.E. of regression $\quad 0.006192$ Sum squared resid $\quad 0.001495$

Durbin-Watson stat $\quad 0.595647$ Long-run variance $\quad 8.05 \mathrm{E}-05$

\section{2 - Inferior a 2}

\section{1-2015}

DC Líquida

\begin{tabular}{lrlll}
\hline \hline Variable & Coefficient & Std. Error & t-Statistic & Prob. \\
\hline \hline DCLPIB(-1) & 0.066144 & 0.014390 & 4.596395 & 0.0000 \\
YVAR & $-4.17 \mathrm{E}-11$ & $2.10 \mathrm{E}-10$ & -0.198444 & 0.8428 \\
\hline \hline R-squared & 0.356412 & Mean dependent var & 0.011132 \\
Adjusted R-squared & 0.308968 & S.D. dependent var & 0.026380 \\
S.E. of regression & 0.021929 & Sum squared resid & 0.150042 \\
Long-run variance & 0.000835 & & & \\
\hline \hline
\end{tabular}

DC Bruta

\begin{tabular}{lrlll}
\hline \hline Variable & Coefficient & Std. Error & t-Statistic & Prob. \\
\hline \hline DCPIB(-1) & 0.062473 & 0.012780 & 4.888149 & 0.0000 \\
YVAR & $-3.09 \mathrm{E}-11$ & $1.95 \mathrm{E}-10$ & -0.158657 & 0.8740 \\
\hline \hline R-squared & 0.407358 & Mean dependent var & 0.011132 \\
Adjusted R-squared & 0.363670 & S.D. dependent var & 0.026380 \\
S.E. of regression & 0.021044 & Sum squared resid & 0.138165 \\
Long-run variance & 0.000784 & & & \\
\hline \hline
\end{tabular}

\section{8-2015}

DC LíquidaDCL/RCL $<2$

\begin{tabular}{lclll}
\hline \hline \multicolumn{1}{c}{ Variable } & Coefficient & Std. Error & t-Statistic & Prob. \\
\hline \hline \multicolumn{1}{c}{ DCLPIB(-1) } & 0.017158 & 0.018193 & 0.943118 & 0.3468 \\
YVAR & $-2.16 \mathrm{E}-11$ & $1.44 \mathrm{E}-10$ & -0.149811 & 0.8811 \\
\hline \hline R-squared & 0.223397 & Mean dependent var & 0.004327 \\
Adjusted R-squared & 0.227442 & S.D. dependent var & 0.016791 \\
S.E. of regression & 0.014759 & Sum squared resid & 0.041823 \\
Durbin-Watson stat & 1.530491 & Long-run variance & 0.000308 \\
\hline \hline DC Bruta & & & & \\
\hline \hline \multicolumn{1}{c}{ Variable } & Coefficient & Std. Error & t-Statistic & \multirow{2}{*}{ Prob. } \\
\hline \multicolumn{1}{c}{ DCPIB(-1) } & 0.018218 & 0.013975 & 1.303686 & 0.1939 \\
YVAR & $-3.56 \mathrm{E}-11$ & 1.35E-10 & -0.264489 & 0.7917 \\
\hline \hline R-squared & 0.321200 & Mean dependent var & 0.004327 \\
Adjusted R-squared & 0.324736 & S.D. dependent var & 0.016791 \\
S.E. of regression & 0.013798 & Sum squared resid & 0.036556 \\
Durbin-Watson stat & 1.297723 & Long-run variance & 0.000295 \\
\hline \hline
\end{tabular}


2001-2020

DC Líquida

\begin{tabular}{lcccc}
\multicolumn{1}{c}{ Variable } & Coefficient & Std. Error & t-Statistic & Prob. \\
\hline \hline \multicolumn{1}{c}{ DCLPIB(-1) } & 0.037800 & 0.013037 & 2.899357 & 0.0040 \\
YVAR & $-4.10 \mathrm{E}-19$ & $4.45 \mathrm{E}-19$ & -0.921644 & 0.3574 \\
\hline \hline R-squared & 0.573323 & Mean dependent var & 0.008121 \\
Adjusted R-squared & 0.442132 & S.D. dependent var & 0.023674 \\
S.E. of regression & 0.017683 & Sum squared resid & 0.108810 \\
Long-run variance & 0.000497 & & \\
\hline \hline
\end{tabular}

\begin{tabular}{lrlrl}
\hline \hline DC Bruta & & & & \\
\hline \hline \multicolumn{1}{c}{ Variable } & Coefficient & Std. Error & t-Statistic & Prob. \\
\hline \hline DCPIB(-1) & 0.030733 & 0.012536 & 2.451565 & 0.0147 \\
YVAR & $-5.54 \mathrm{E}-19$ & $4.64 \mathrm{E}-19$ & -1.196040 & 0.2324 \\
\hline \hline R-squared & 0.489178 & Mean dependent var & 0.008121 \\
Adjusted R-squared & 0.380203 & S.D. dependent var & 0.023674 \\
S.E. of regression & 0.018638 & Sum squared resid & 0.130268 \\
Long-run variance & 0.000633 & & & \\
\hline \hline
\end{tabular}

\section{8-2020}

DC Líquida

\begin{tabular}{lrlll}
\hline \hline \multicolumn{1}{c}{ Variable } & Coefficient & Std. Error & t-Statistic & Prob. \\
\hline \hline \multicolumn{1}{c}{ DCLPIB(-1) } & 0.021357 & 0.010736 & 1.989291 & 0.0475 \\
YVAR & $-4.79 E-20$ & $2.83 E-19$ & -0.169353 & 0.8656 \\
\hline \hline R-squared & 0.159584 & Mean dependent var & 0.002544 \\
Adjusted R-squared & 0.162278 & S.D. dependent var & 0.014540 \\
S.E. of regression & 0.013308 & Sum squared resid & 0.055256 \\
Durbin-Watson stat & 1.388291 & Long-run variance & 0.000261 \\
\hline \hline
\end{tabular}

DC Bruta

\begin{tabular}{lrlll}
\hline \hline \multicolumn{1}{c}{ Variable } & Coefficient & Std. Error & t-Statistic & Prob. \\
\hline \hline \multicolumn{1}{c}{ DCPIB(-1) } & 0.012995 & 0.008339 & 1.558205 & 0.1202 \\
YVAR & $-1.06 \mathrm{E}-19$ & $2.74 \mathrm{E}-19$ & -0.386959 & 0.6991 \\
\hline \hline R-squared & 0.250517 & Mean dependent var & 0.002544 \\
Adjusted R-squared & 0.252920 & S.D. dependent var & 0.014540 \\
S.E. of regression & 0.012567 & Sum squared resid & 0.049277 \\
Durbin-Watson stat & 1.273540 & Long-run variance & 0.000245 \\
\hline \hline
\end{tabular}

